\title{
CRESCIMENTO DE MUDAS DE ESPÉCIES ARBÓREAS NATIVAS, EM PLANTIO DE ENRIQUECIMENTO DO SUB- BOSQUE DE UM FRAGMENTO FLORESTAL.
}

\author{
ARY VIEIRA DE PAIVA \\ Engenheiro Agrônomo
}

Orientador: Prof. Dr. FÁBIO POGGIANI

\begin{abstract}
Dissertação apresentada à Escola Superior de Agricultura "Luiz de Queiroz", Universidade de São Paulo, para obtenção de título de Mestre em Ciências, Área de Concentração: Ciências Florestais.
\end{abstract}

PIRACICABA

Estado de São Paulo - Brasil

Setembro - 1997 
Dados Internacionais de Catalogação na Publicação (CIP) DIVISÃo DE BIBLIOTECA E DOCUMENTAÇÃO - Campus "Luiz de Queiroz"/USP

Paiva, Ary Vieira de

Crescimento de mudas de espécies arbóreas nativas, em plantio de enriquecimento do sub-bosque de um fragmento florestal / Ary Vieira de Paiva. - - Piracicaba, 1997. 84 p. : il.

Dissertação (mestrado) - Escola Superior de Agricultura Luiz de Queiroz, 1997. Bibliografia.

1. Muda 2. Sub-bosque 1. Titulo 


\section{CRESCIMENTO DE MUDAS DE ESPÉCIES ARBÓREAS NATIVAS, EM PLANTIO DE ENRIQUECIMENTO DO SUB- BOSQUE DE UM FRAGMENTO FLORESTAL.}

ARY VIEIRA DE PAIVA

Aprovada em 20.11.1997

Comissão julgadora:

Prof. Dr. Fábio Poggiani

ESALQ/USP

Prof. Dr. Antonio Augusto Lucchesi

ESALQ/USP

Prof. Dr. Antonio Natal Gonçalves

ESALQ/USP

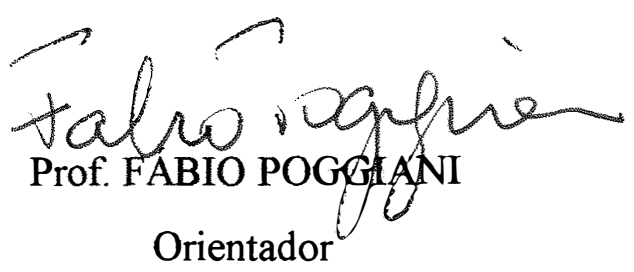


Dedico esse trabalho à memória de meu pai, que sempre afirmou ser o saber a maior riqueza de um homem e à minha mãe pelo seu otimismo e entusiasmo de viver. 


\section{AGRADECIMENTOS}

Ao meu orientador, Prof. Dr. Fábio Poggiani, por sua atenção, dedicação, respeito e incentivo ao meu trabalho.

Aos meus colegas de mestrado em Ciências Florestais, especialmente ao Samir, que sempre dividiram comigo momentos de intenso trabalho e de intensa amizade e afeto.

Aos meus colegas da Divisão de Meio Ambiente da CPFL, que sempre souberam entender as dificuldades da compatibilização do trabalho profissional e do trabalho acadêmico, me apoiando e estimulando.

À equipe de funcionários do viveiro de mudas da U. He. São Joaquim, em especial ao amigo José Ivo, pelo apoio nas tarefas de produção de mudas, instalação do ensaio em campo e coleta de dados.

Às amigas Denise e Jane pela revisão de texto e referências bibliográficas.

A CAPES, pela concessão de bolsa para realização deste trabalho acadêmico.

Ao Prof. Dr. Hilton Thadeu Z. do Couto, pelas orientações na análise dos dados experimentais.

À Seção de Climatologia do Instituto Agronômico de Campinas, pela atenção dispensada e fornecimento de dados meteorológicos. 


\section{SUMÁRIO}

Página

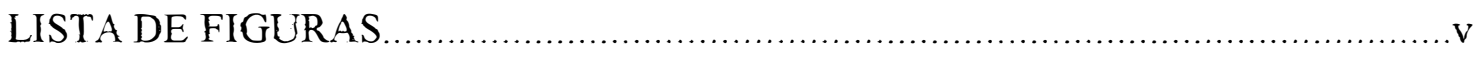

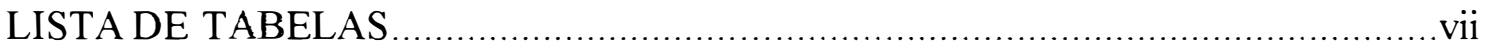

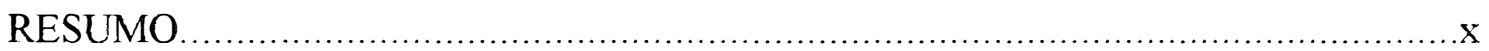

SUMMARY

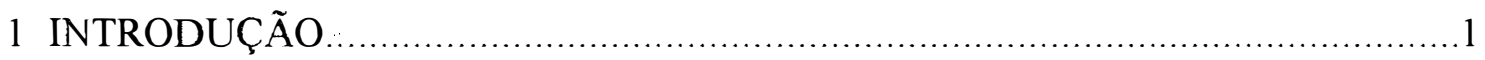

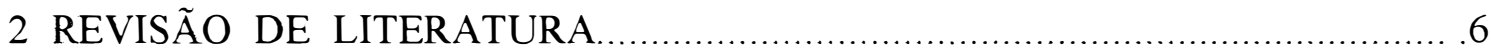

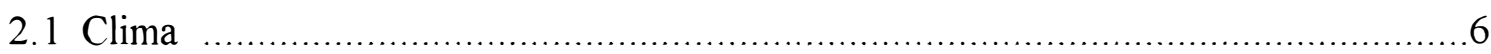

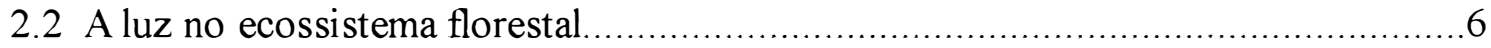

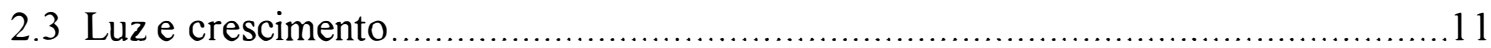

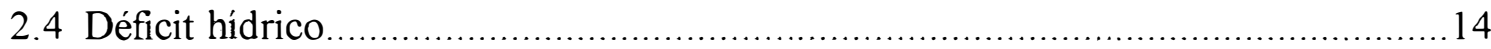

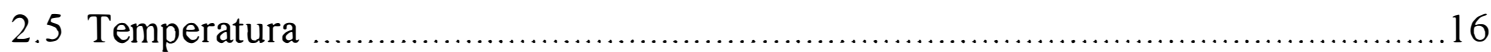

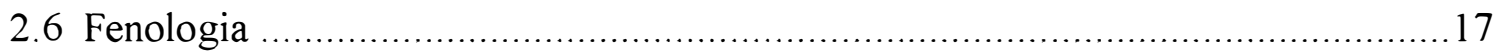

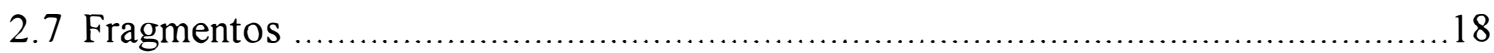

2.8 Espécies arbóreas nativas com potencial silvicultural e enriquecimento............... 21

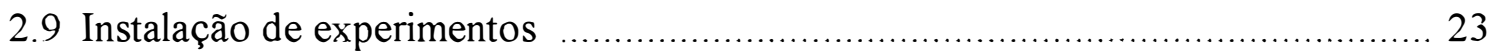

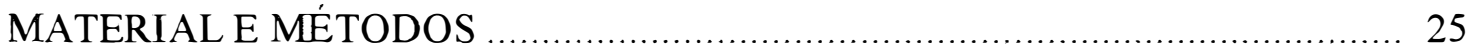

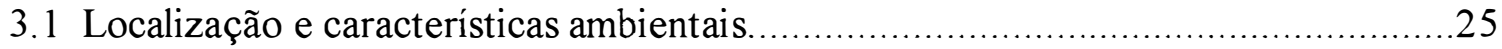

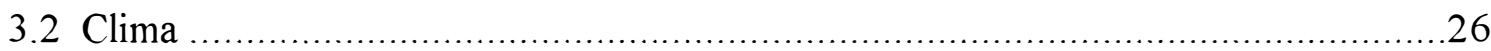

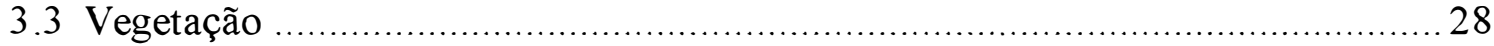

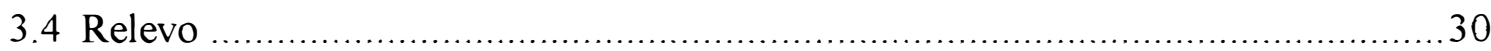

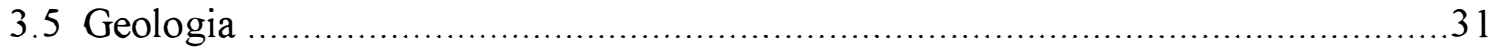

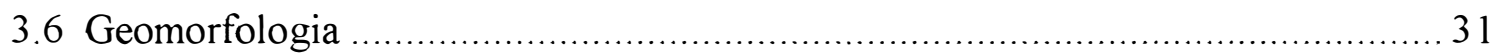

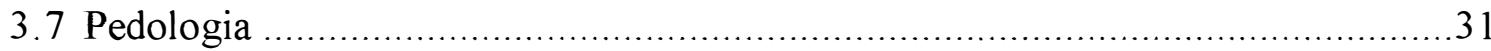

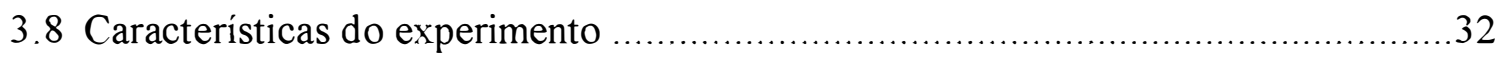

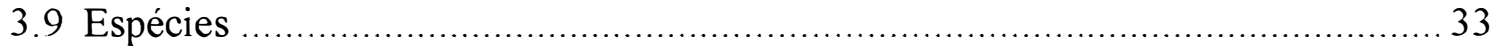


3.9.1 Angico-vermelho (Anadenanthera macrocarpa) ............................................

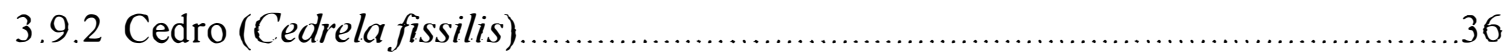

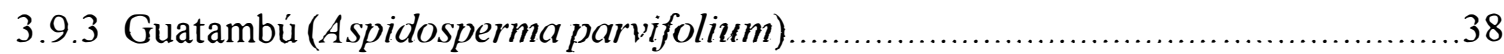

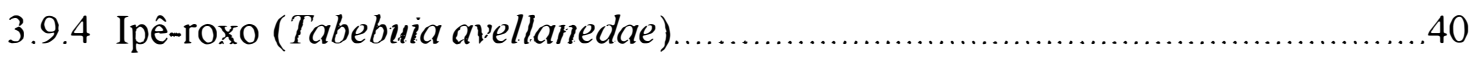

3.9.5 Jatobá (Hymenaea courbaril L. var. stilbocarpa) ........................................42

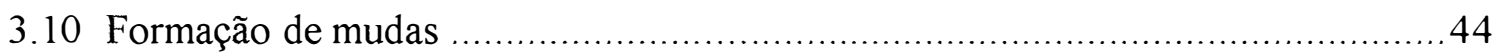

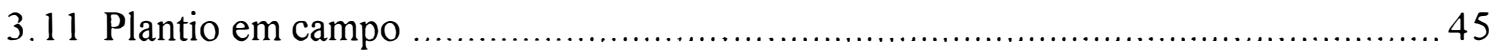

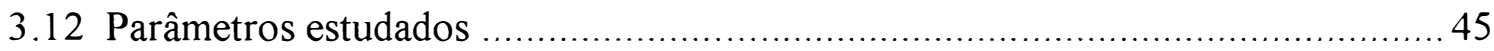

3.12.1 Luz: intensidade de luz e índice de luminosidade relativa ........................ 45

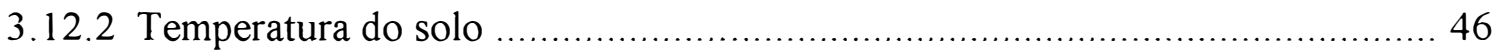

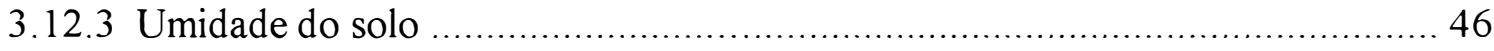

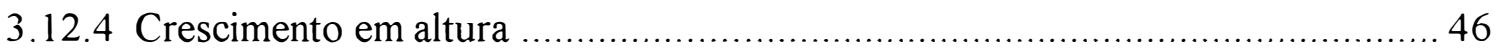

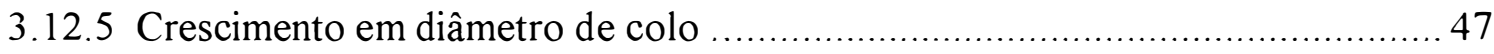

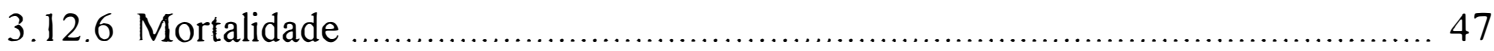

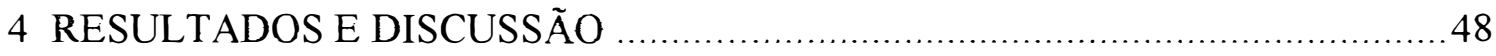

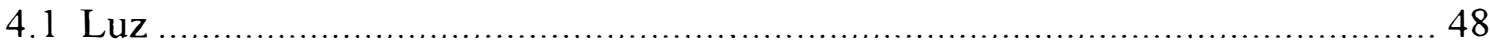

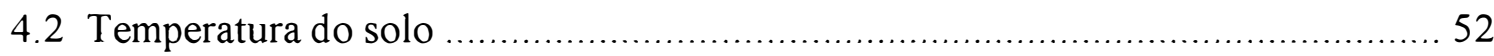

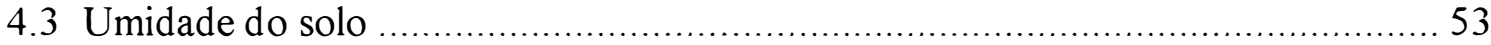

4.4 Considerações sobre os fatores ambientais e suas influências ..............................55

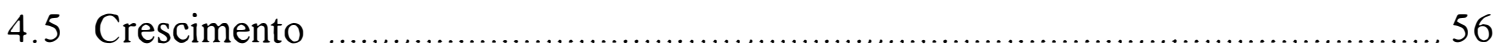

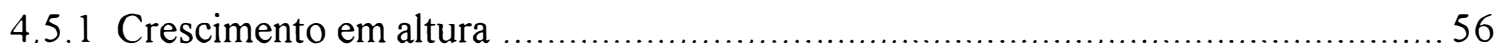

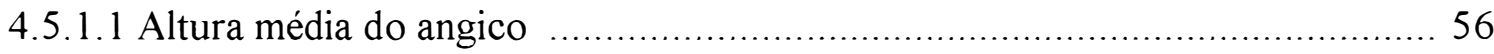

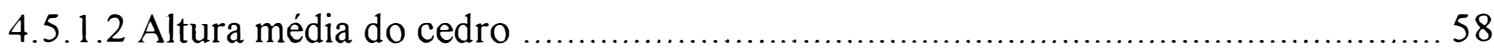

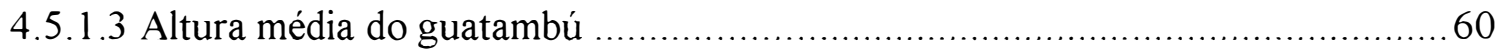

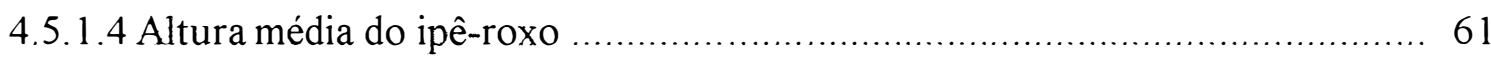

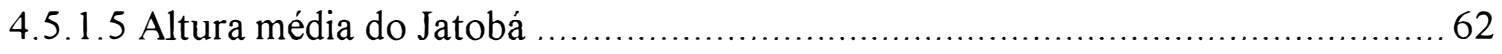

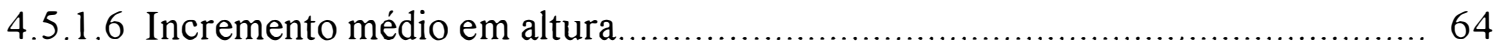

4.5.2 Crescimento em diâmetro .......................................................... 67

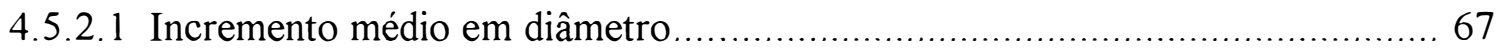


4.6 Mortalidade. 70

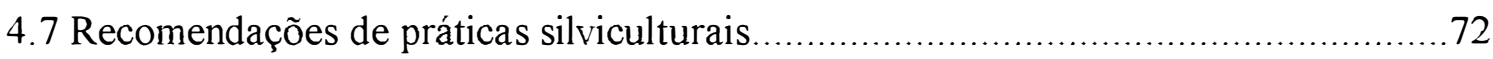

4.8 Considerações sobre metodologia para implantação de ensaios de

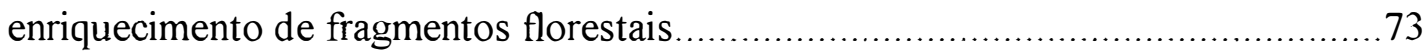

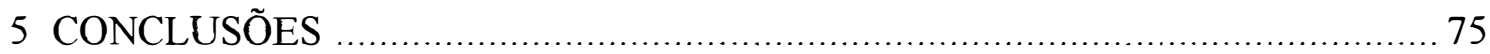

REFERÊNCIAS BIBLIOGRÁFICAS _................................................ 77 
Página

1. Localização da área experimental no Estado de São Paulo .............................. 25

2. Balanço hídrico da região de Ribeirão Preto durante os anos de 1995 e $1996 \ldots \ldots . . .27$

3. Ilustração de parte da borda do fragmento onde o ensaio foi instalado.................. 29

4. Croquis da área da Usina mostrando a localização das áreas experimentais........... 30

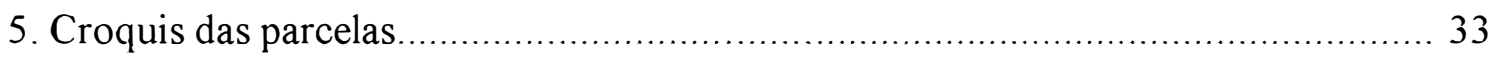

6. Ilustração de muda de angico vermelho........................................... 35

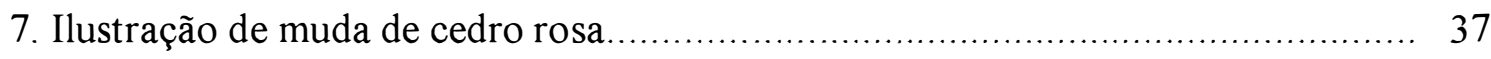

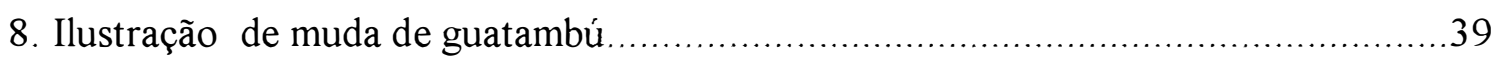

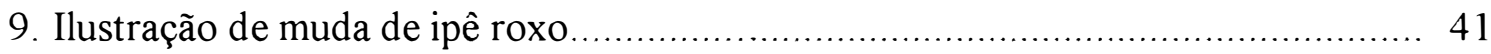

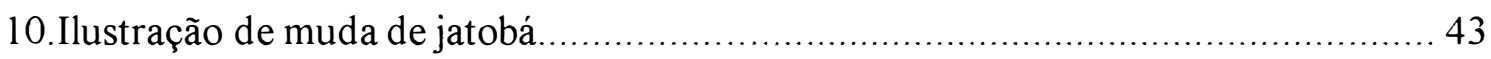

11.Gráfico da intensidade luminosa a céu aberto na área experimental.................. 48

12. Gráfico da intensidade luminosa sob dossel de fragmento........................... 49

13. Gráfico do Índice de Luminosidade Relativa - ILR \% .............................. 50

14.Gráfico das médias de temperatura do ar e do solo ................................ 52

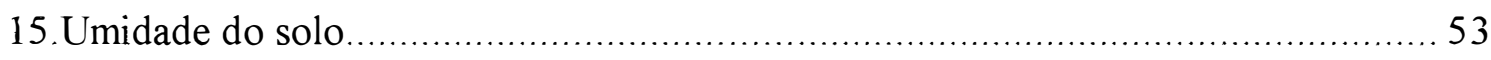

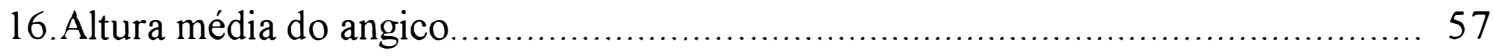

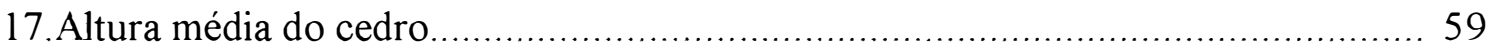

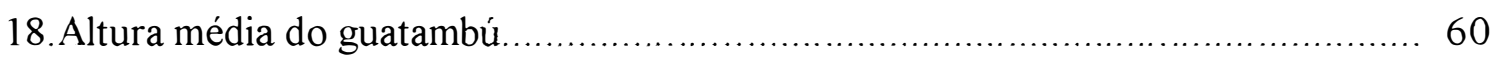

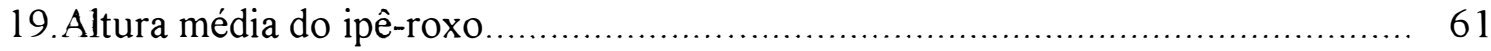

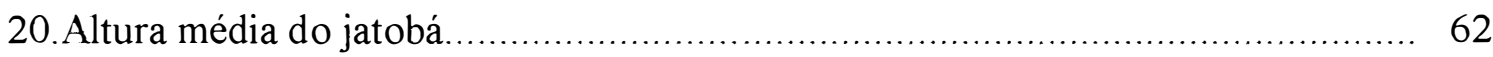


página

21 Incremento médio em altura. 65

22. Incremento médio em diâmetro de colo 69

23. Mortalidade de mudas. 71 
Página

1. Temperatura média mensal da região de Ribeirão Preto.................................26

2. Precipitação pluviométrica total em mm da região de Ribeirão Preto..................... 27

3. Comparação de médias de alturas inicial e final em centímetros entre as

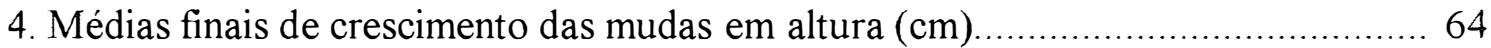

5. Diâmetros médios de caule inicial e final em milímetros...................................67

6. Comparação do incremento médio em diâmetro de caule entre as cinco espécies... 68 


\title{
CRESCIMENTO DE MUDAS DE ESPÉCIES ARBÓREAS NATIVAS EM PLANTIO DE ENRIQUECIMENTO DO SUB-BOSQUE DE UM FRAGMENTO FLORESTAL
}

\author{
Autor: Ary Vieira de Paiva \\ Orientador: Prof. Dr. Fábio Poggiani
}

\section{RESUMO}

Poucos dados científicos foram encontrados sobre os efeitos do meio ambiente no crescimento de mudas de espécies arbóreas em sub-bosque de fragmentos florestais remanescentes. Neste experimento, instalado na Usina Hidroelétrica de São Joaquim, Guará - SP, a $20^{\circ} 34^{\prime}$ de latitude sul e a $47^{\circ} 47^{\prime}$ de longitude oeste, observouse que a luminosidade natural encontrada sob o dossel foi baixa, semelhante à das florestas primárias, variando de 0,83 a 2,0 Klux. A temperatura média do solo permaneceu ligeiramente abaixo da temperatura média do ambiente. A umidade do solo acompanhou a distribuição da precipitação pluviométrica, atingindo níveis abaixo do ponto de murchamento no período de déficit hídrico. O angico (Anadenanthera macrocarpa) cresceu em um ano $25,82 \mathrm{~cm}$, como também o cedro (Cedrella fissilis) 25,61 cm, seguidos pelo jatobá (Hymenaea courbaril L. var. stilbocarpa) 20,30 cm, 
guatambú (Aspidosperma parvifolium) 14,24 cm e ipê-roxo (Tabebuia avellanidae) $13,51 \mathrm{~cm}$. O cedro apresentou o maior incremento médio em diâmetro de colo, totalizando $6,14 \mathrm{~mm}$ no mesmo período .A taxa de mortalidade foi baixa para todas as espécies, sendo maior para o cedro, atingindo 5,09\%, devido principalmente ao ataque da broca Hypsipyla grandella. 


\title{
SEEDLINGS GROWTH OF NATIVE TREE SPECIES IN ENRICHMENT PLANTATION OF THE UNDERSTORY VEGETATION IN A FOREST FRAGMENT.
}

\author{
Author: Ary Vieira de Paiva \\ Adviser: Prof. Dr. Fábio Poggiani
}

SUMMARY

There are a few scientific data about the effect of the environment on the growth of the seedling tree species in the understory of remaning forest fragment. In this experiment, situated in Guará - SP, at $20^{\circ} 34^{\prime} \mathrm{S}$ and at $47^{\circ} 47^{\prime} \mathrm{W}$, it was observed that the natural luminosity under the canopy was low, ranging from 0.83 to $2.0 \mathrm{Klux}$. The soil temperature remained slightly below the air temperature all the time. The soil moisture followed the rainfall pattern, reaching leavels below the wilting percentage during the drought period. Anadenathera macrocarpa grew $25.8 \mathrm{~cm}$, Cedrella fissilis $25.6 \mathrm{~cm}$, Hymenaea courbaril L. var. stilbocarpa $20.3 \mathrm{~cm}$, Aspidosperma parvifolium, $14.2 \mathrm{~cm}$ and Tabebuia avellanedae $13.5 \mathrm{~cm}$. Cedrella fissilis got the major radial grouth average, with $6.1 \mathrm{~mm}$. The mortality rate was low to all the species, although a little bit higher for the Cedrella fissilis(5,09\%), due to the Hypsipyla grandella attack. 


\section{INTRODUÇÃO}

A preocupação com o estágio de degradação da vegetação de porte arbóreo, bem como de sua recuperação, manutenção ou conservação e manejo tem mobilizado ecologistas, técnicos, empresários, políticos e mesmo uma parcela significativa da população não vinculada a grupos específicos.

O processo de ocupação do País se deu e ainda continua acontecendo sem um planejamento que contemple parâmetros ambientais dentre os paradigmas tradicionais utilizados pelos gestores públicos e privados, provocando perdas muitas vezes irreparáveis para as gerações futuras.

Pelo fato da maioria dos atuais ocupantes do país aqui terem desembarcado pelo Atlântico, a ocupação seguiu o sentido leste-oeste, como na maioria dos países da América. As vegetações mais próximas à costa atlântica foram quase que totalmente destruídas, como os manguesais e a mata atlântica que ocupava $12 \%$ do território brasileiro, hoje reduzida em mais de 95\%, segundo DPRN(1991). O processo de degradação dos demais biomas naturais brasileiros seguiu os passos do processo de expansão da fronteira agrícola e da exploração mineral, como é o caso dos Cerrados do Brasil Central, Caatinga, Pantanal do Mato Grosso, e Floresta Amazônica, dentre outros.

No Estado de São Paulo, não poderia ter sido diferente. Os recursos naturais foram gradativamente sendo degradados pela expansão da fronteira agrícola. Mais recentemente, os remanescentes do meio natural têm sido ameaçados pela ocupação desordenada do solo urbano, não só nas periferias das cidades mas também na grande São Paulo, onde as populações excluídas pelo modelo de desenvolvimento econômico atual sub-habitam e degradam e, ainda, em projetos imobiliários de alto padrão no litoral 
de São Paulo, sendo um caso gritante o de Ilha Bela, onde a paisagem natural das montanhas, mata atlântica e praias, dão lugar a mansões e condomínios luxuosos privados.

A cobertura original do Estado foi reduzida dos seus $81,8 \%$, segundo Victor (1975), para 8,3\% em 1973, segundo Serra Filho et alii (1975), chegando a 7,16\% em 1993 (Instituto Florestal, 1993). Os remanescentes da vegetação natural do Estado são fragmentos florestais predominantemente pequenos, localizados em propriedades particulares, abandonados e sujeitos a toda sorte de perturbações, sendo os últimos depositários da biodiversidade nativa de boa parte de nossas florestas (Viana et alii, 1992). Este fenômeno de fragmentação é muito mais forte em nossas florestas de planalto, típicas do interior paulista.

Considerando serem os fragmentos áreas improdutivas sob o ponto de vista de exploração agrícola, não propiciando nenhum retorno financeiro às propriedades rurais onde se encontram, significando portanto apenas despesas com manutenção, tornálos áreas produtivas através do seu enriquecimento com espécies florestais de interesse econômico e promover um manejo florestal sustentado, poderá ser um caminho no sentido de sua recuperação e preservação. Mas para tanto, se faz necessário a busca de conhecimento técnico científico, já que os níveis de conhecimento atuais sobre fragmentos, sobre a autoecologia de suas espécies arbóreas com potencial de mercado e seu desenvolvimento silvicultural a pleno sol e sob diversos níveis de luz, como ocorre em condições naturais nos fragmentos, tanto em ocorrências sob dossel quanto em clareiras, são ainda insatisfatórios para romper com as práticas empíricas utilizadas até o momento. Clements em 1905, lançava as bases teóricas na área de métodos e técnicas de pesquisa ecológica, em sua obra "Research Methods in Ecology" segundo Acot (1990), constituindo-se um indicador da profissionalização nascente desta ciência. Outras ferramentas e métodos foram criados ou adaptados de outras áreas de pesquisa, o que nos permite o desenvolvimento da pesquisa ambiental em busca deste conhecimento.

Nesta perspectiva, se faz necessário o desenvolvimento de pesquisas sobre as espécies florestais em si e de suas interações com o ambiente natural. Quais 
seriam as características de cada espécie bem como as condições naturais de sobrevivência e desenvolvimento das mesmas, como necessidade de luz, de temperatura, umidade do solo e ar, competição e interação com outras espécies? Será adequado o desenvolvimento destas espécies sob dossel florestal? Quais problemas surgirão? Será possivel, tendo em mãos informações técnico científicas, promover o enriquecimento destes fragmentos com espécies de potencial silvicultural, numa perspectiva da preservação de suas características naturais através de manejo florestal sustentável? Os métodos atuais de pesquisa nesta área são de fato satisfatórios? As pesquisas têm sido desenvolvidas, em sua maioria em condições artificiais, como casas de vegetação, viveiros e campos experimentais, sendo poucos os trabalhos sobre o desenvolvimento de espécies arbóreas nativas em condições naturais.

Pelo nível de dificuldade apresentado pela complexidade de variáveis do ambiente natural que poderiam estar influenciando nos resultados, dificultando o isolamento dos efeitos de um fator que se pretenda estudar, associado a custos elevados tem levado muitos pesquisadores a tentar simular uma situação natural para realização de suas pesquisas, extrapolando seus dados para as condições naturais.

Trabalhos de pesquisa já desenvolvidos sobre crescimento de algumas espécies nativas em função da influência da luminosidade têm apontado respostas diferenciadas entre as espécies, principalmente considerando seu "status" sucessional, apontando para uma necessidade de sombreamento nos estádios iniciais de crescimento, segundo vários autores (Inoue, 1977; Inoue \& Torres,1980; Souza,1981; Engel \& Poggiani,1990; Poggiani et alii, 1992). Por outro lado, tem demostrado a necessidade de incremento de luz para completarem seu pleno desenvolvimento, associadas a eventos como a ocorrência de clareiras (Martinez-Ramos, 1985).

A necessidade de se estudar os efeitos da disponibilidade de água no solo sob florestas mesófilas semidecíduas do interior paulista sobre os estádios iniciais de desenvolvimento das espécies arbóreas é de extrema importância. Nesta região, ocorrem 
precipitações acima de $1.400 \mathrm{~mm} / \mathrm{ano}$, mas sua distribuição ao longo do mesmo é sazonal, existindo um período de déficit hídrico acentuado, segundo dados do * IAC.

Os efeitos da temperatura ambiente e do solo no desenvolvimento de espécies florestais nativas também são importantes de ser conhecidos, por serem fatores primários e fundamentais, principalmente na distribuição das espécies. Um fator climático eventual, mas cíclico é a ocorrência de geadas, que também tem uma ação seletiva sobre muitas espécies arbóreas. Outra influência importante da temperatura seria quanto aos aspectos fitossanitários das espécies, podendo ter ação seletiva sobre as mesmas, fator importante para orientação na escolha das espécies nativas de ocorrência geral para uma região com este valor muito abaixo ou muito acima da média específica.

Os ensaios de campo sobre o desenvolvimento de espécies arbóreas nativas sob condições naturais vêm sendo desenvolvido por vários pesquisadores com várias espécies ( Inoue, 1977, Inoue \& Torres, 1980; Souza, 1981; Carvalho, 1982; Jesus et alii, 1982; Gurgel Filho et alii, 1982a; CONIF, 1986; Molas \& Pretzcsch, 1989; Martins, 1990). Ainda que seja consenso a existência de pequena quantidade de informações sobre o assunto, esta constatação aponta para um grande campo potencial de pesquisa

Esse trabalho não tem a pretensão de dar respostas a todas estas questões técnicas, mas de contribuir no processo de busca de informações de maneira científica, sobre o comportamento de algumas espécies florestais arbóreas nativas de interesse comercial e as características de seu ambiente natural e de práticas silviculturais que possam servir de base para orientação aos produtores rurais.

Seus objetivos básicos são acompanhar e analisar o comportamento de mudas de cinco espécies arbóreas nativas, cultivadas sob fragmento em regeneração, avaliando seu crescimento e sobrevivência; acompanhar variáveis ambientais que possam afetar o desenvolvimento dos estados juvenis das espécies naquelas condições; estabelecer critérios que possam servir para orientação à práticas silviculturais; e levantar questões metodológicas sobre a implantação de ensaios ecológicos florestais em

\footnotetext{
* Dados não publicados, fornecidos pela Seção de Climatologia do IAC - Campinas em 1997.
} 
condições de campo, para uma contribuição aos futuros ensaios científicos a ser instalados. 


\section{REVISÃO DE LITERATURA}

\subsection{Clima}

Segundo Stadtmuller (1988), macroclima descreve as condições climáticas em extensões horizontais de centenas a milhares de quilômetros quadrados e por cima da influência imediata da vegetação. Conforme o mesmo autor, microclima se determina como o clima de espaços reduzidos e definidos, o clima próximo às superficies.

A floresta, através de suas superfícies extensas (sobretudo nas copas), se encontra permanentemente em estreito contato com a atmosfera. Por esta razão, a floresta, de forma intensa participa dos processos meteorológicos e dos processos de intercâmbio de matéria e energia. Os elementos meteorológicos principais (radiação, temperatura, vento, precipitação e evapotranspiração) são modificados fortemente pela floresta, segundo Stadtmuller (1988).

Estudos realizados por Kratzer, citado por Sattler (1992), comprovam que as áreas desprovidas de vegetação tornam-se muito quentes ao meio dia e frias à noite. As áreas densamente vegetadas apresentam uma temperatura sem grandes variações diurnas, sendo consideravelmente mais frescas que as anteriores.

\subsection{A Luz no Ecossistema Florestal:}

A energia é um insumo fundamental e indispensável na gênese, desenvolvimento e manutenção de qualquer forma de vida: não existe vida sem energia. A energia solar é a fonte da vida utilizada para a formação de toda biomassa através da fotossíntese, que transforma a energia luminosa em química, constituindo as bases necessárias ao estabelecimento de uma cadeia alimentar (Spurr \& Barnes, 1980). 
Os fatores do meio ambiente não são forças independentes, isoladas que operam sobre as plantas, sendo mais influências interdependentes e interrelacionadas que devem ser consideradas globalmente. São fatores ambientais mais importantes os climáticos, como a radiação solar, temperatura do ar, umidade do ambiente, vento, iluminação e concentração de $\mathrm{CO}_{2}$ no ar, fatores do solo e fatores bioquímicos. O clima seria a interrelação entre a radiação solar e a atmosfera da terra e seus desdobramentos, segundo o mesmo autor.

A quantidade total de energia luminosa que atinge anualmente a terra é muito grande, mas muito pouco é diretamente usada pelas plantas. Da radiação solar que atinge as plantas, uma parte é absorvida, uma parte é refletida e outra parte é transmitida. A radiação refletida pela superficie da terra (albedo) ao espaço representa cerca de 1/3 da radiação total recebida. Ainda Spurr (1980) afirma que as nuvens refletem a maior parte da luz. Aproximadamente $1 / 6$ da radiação é refletida pela superficie da vegetação, segundo Whatley \& Whatley (1982). Assim, a natureza e qualidade da radiação solar recebida sobre a superfície da terra afeta a distribuição e o crescimento da floresta. A quantidade de luz que atinge o solo de uma floresta depende das espécies presentes e da densidade das sucessivas camadas abaixo do dossel e em geral, quanto maior for a quantidade de luz que atinge os níveis mais baixos, melhor será o desenvolvimento das camadas baixas da vegetação. Sob um dossel, uma grande parte da luz que atinge as folhas situadas mais abaixo está sob forma de alguns raios de sol, que penetram através da aberturas. Quando as aberturas para a luz são pequenas, cada raio de sol persistirá durante um intervalo de tempo relativamente curto, cuja duração depende do tamanho da brecha e da mudança da posição do sol em relação a ela, que são importantes fontes de luz para as plantas desenvolvidas nas camadas inferiores, principalmente em florestas densas. Ainda Whatley \& Whatley (1982) afirmam que em florestas decíduas há grandes diferenças estacionais na quantidade de luz que consegue atingir o piso florestal.

A luz é usada como um verdadeiro "relógio" biológico pelas plantas e animais, através do fotoperiodismo, por ser a única constante climática completamente 
segura, mas nem todos os efeitos da luz nos ecossistemas complexos até hoje são bem compreendidos. Sabe-se que a estrutura da comunidade vegetal tanto afeta a luz como é afetada por ela. Contudo, os mesmos autores consideram que grandes diferenças de intensidades de luz podem ter pouca influência sobre o crescimento, e é somente quando a intensidade de luz atinge um certo nível limitante crítico para uma determinada espécie que o efeito sobre a planta passa a ser mensurável.

A disponibilidade de luz para plântulas e estágios juvenis de espécies arbóreas encontradas sob dossel florestal para seu pleno desenvolvimento pode estar vinculado à ocorrência de eventos que venham a aumentar a disponibilidade deste fator. Nos últimos anos, o processo de formação de clareiras em florestas e sua importância vêm merecendo a atenção de muitos pesquisadores. Martinez-Ramos (1985) afirma que a dinâmica de abertura de clareiras promove mudanças ambientais no interior de florestas, tornando bastante heterogêneas as distribuições de fatores microclimáticos como luz, água, solo e nutrientes e que existem atributos nos ciclos de vida das árvores que possivelmente evoluíram com as clareiras e são importantes para o entendimento de processos ecológicos, como a sucessão cíclica das florestas, contidos em três componentes demográficos básicos: crescimento, sobrevivência e reprodução.

A energia absorvida pela planta pode ser armazenada como calor e convertida em energia fotoquímica por meio da fotossíntese. Pode ser devolvida novamente ao meio por radiação, condução ou convecção do calor ou por evaporação e transpiração (evapotranspiração).

A soma aritmética do fluxo de energia com seu sinal correspondente de uma superficie se denomina radiação líquida.

Cerca de 4 a $5 \%$ da energia solar principal é absorvida ou convertida em energia química, mas somente 1 a $2 \%$ da energia solar total é utilizada na fotossíntese.

Os comprimentos de onda da massa de radiação solar se dividem em 3 regiões, denominadas ultravioleta, visível e infravermelho. Os raios ultravioleta (mais curtos) são quase que totalmente absorvidos pela atmosfera. A radiação, com comprimento de 
ondas entre 0,4 a 0,7 $\mu \mathrm{m}$ (400 a $700 \mathrm{~nm}$ ), é visível ao olho humano e corresponde à metade da energia solar total que chega à terra,( Spurr 1980).

As medidas de incidência de luz para estudos ecológicos podem ser de várias formas, mas muitas se baseiam em médias que representam o estímulo do olho humano pela energia radiante, denominada iluminação, medida em lumens por pé ou metro quadrado. $\mathrm{O}$ termo luz se utiliza porque está bem estabelecido que a radiação solar nas bandas visíveis do espectro é que afeta o processo de fotossíntese.

Ainda que a iluminação não seja uma indicação confiável de energia da radiação no espectro visível para processos biológicos, tem sido amplamente usada devido à disponibilidade de aparelhos de medição fotoelétricos que estão calibrados para medir a resposta visual.

A interceptação da radiação solar pela vegetação é bastante variável, dependendo tanto da densidade de folhagem ao longo do ciclo fenológico anual do espécimen, quanto às condições de transparência do céu e do ângulo de incidência dos raios solares sobre a vegetação (Sattler, 1992).

Para Spurr (1980), somente parte da radiação solar chega ao piso da floresta. O índice de luminosidade relativa - ILR, expresso em porcentagem da luz encontrada sob o dossel comparada a luz total em aberto, encontra-se entre 50 a $80 \%$ da luz total sob árvores de folhas caducas sem folhas; 10 a $15 \%$ sob florestas abertas de pinus; 1 a $5 \%$, sob folhagens de madeiras duras temperadas, e, de 0,25 a $2 \%$, sob floresta tropical chuvosa.

Não só a quantidade de luz é modificada ao atravessar o dossel da floresta, mas também sua qualidade. As folhas do dossel refletem de 10 a $25 \%$ da radiação do espectro visível que recebem. A qualidade da radiação que chega ao sub-bosque depende tanto das propriedades óticas das folhas como da luz direta ou dispersa que penetra nas aberturas do dossel. Sob bosques muito densos, a fotossíntese líquida ocorre só quando as folhas estão banhadas por manchas de luz solar. Muitas espécies de sub-bosque sob florestas densas de folhas caducas podem estabelecer ganhos líquidos de crescimento somente 
durante os períodos em que as árvores do dossel estiverem sem folhas. Quanto menor for a radiação maior será a deterioração das raízes de plântulas do banco de plântulas (Spurr 1980).

Segundo Kramer \& Koslowski (1972), a luz afeta o crescimento das árvores de maneira direta, através de sua qualidade, duração e intensidade, atuando sobre a fotossintese, síntese de clorofila e abertura estomática.

Populações vegetais adaptam-se, tanto na estrutura quanto na taxa de crescimento à luz prevalecente e a outras condições ambientais.

A forma das folhas e também seu ângulo de inclinação têm um importante papel nesta competição pela luz. Estas diferenças podem ser genéticas e permanentes ou ambientais e temporárias( Whatley \& Whatley, 1982). A competição entre as folhas pela luz também resulta no desenvolvimento das folhas de "sol" e "sombra", que são encontradas em diferentes posições na mesma árvore.

As plantas que crescem sob condições de luz de sombra desenvolvem uma estrutura e uma aparência diferentes das mesmas plantas que crescem ao sol pleno.

Algumas plantas exibem pouca elasticidade na anatomia da folha devido às diferenças muito pequenas entre folhas de sol e de sombra.

A maior parte das árvores florestais tem faculdade de desenvolver diferentes estruturas anatômicas em suas folhas quando crescem à sombra ou ao sol. As folhas de sombra, quando comparadas às de sol de uma mesma árvore, apresentam-se mais delgadas, mais lobuladas, com maior superficie por unidade de peso, epiderme mais fina, com mais espaços intercelulares e parênquima esponjoso, menos tecidos condutivos e poucos estômatos ( Spurr, 1980).

A folha de sombra típica mantém a fotossíntese quando está protegida do efeito deteriorante do excesso de luz e requer menos luz no ponto de compensação, mostrando uma fotossíntese líquida com muito pouca luz.

Quando folhas de sombra são repentinamente expostas à luz total são levadas à morte, por perda de água ou excesso de luz nos cloroplastos. 
Somente uma pequena porcentagem do total de energia luminosa recebida é convertida em energia química, que é armazenada como produto fotossintético e novo material vegetal.

A fotossíntese é afetada pela quantidade e qualidade da radiação solar, mas é consenso entre pesquisadores da área como Amo (1985) que a intensidade tem, nas condições naturais, efeito mais significativo no crescimento das plantas do que a sua qualidade, principalmente quanto ao acúmulo de matéria seca.

Existe uma questão bastante importante quanto à plasticidade de resposta de espécies florestais a diferentes níveis de radiação em seu desenvolvimento. Muitas espécies respondem bem em desenvolvimento estando em ambientes sombreados ou expostas diretamente ao sol, outras não(Fetcher et alii, 1983).

\subsection{Luz e Crescimento}

O crescimento dos vegetais está intrinsecamente ligado a fatores internos aos mesmos (bioquímicos) e a fatores externos, do meio ambiente onde estão inseridos.

A fotossíntese é considerada como sendo o maior processo fisiológico do crescimento, por ser fonte primária de matéria orgânica, segundo Kozlowski (1962), constituindo-se parte de um complexo processo fisiológico global de desenvolvimento vegetal.

A eficiência em crescimento de um vegetal está associada à capacidade de ajuste de seu aparelho fotossintético adaptada às diferentes condições de luz do ambiente, no sentido de otimizar o uso desta fonte de energia.

A análise do crescimento de espécies vegetais arbóreas tem sido muito utilizada para determinar o grau de tolerância das mesmas às diferentes condições de luz disponíveis no ambiente onde se encontram e muitos parâmetros têm sido utilizados para tanto. 
O crescimento em altura é um dos parâmetros mais freqüentemente utilizados. Também podem ser utilizados o diâmetro do caule, produção de matéria seca, relação parte aérea e sistema radicular, área foliar, conteúdo de água nos tecidos vegetais, dentre outros

As plântulas de diferentes espécies variam muito quanto à sua capacidade inicial de crescimento sob diferentes condições de luz.

Muitas espécies têm sido classificadas em grupos opostos por diferentes pesquisadores às suas respostas em crescimento quanto à disponibilidade de luz. No caso do gênero Cedrela sp, Souza (1981) afirma que pesquisadores de diversos países a tem classificado como umbrófilas enquanto outros como tipicamente heliófilas. Possivelmente por utilizarem metodologias diferentes, em condições ambientais específicas pela ampla distribuição das espécies em vários países e pela grande variabilidade de seu material genético.

Estudando as intensidades de luz mais adequadas ao crescimento na fase juvenil de quatro essências florestais nativas do Estado de São Paulo, submetidas aos níveis de sombreamento de 0, 42, 68 e 82 \% durante fase de viveiro, Engel \& Poggiani (1990) observaram que as taxas de crescimento de Tabebuia avellanedae apresentaram maiores médias de altura, matéria seca da parte aérea e área foliar a $82 \%$ de sombra (18\% de luminosidade). Também estabeleceu uma escala de tolerância à sombra na seguinte ordem: A. cearensis $>$ T. avellanedae $>$ Z. tuberculosa $>$ E. speciosa.

Para Inoue (1977), as espécies de Cedrela spp necessitam de um sombreamento para crescer com maior rapidez no estágio juvenil. O crescimento depende não só da intensidade luminosa, mas também do número de horas de insolação diária.

Estudando respostas em crescimento de Araucária Augustifólia (Bert) O. Ktze. sob níveis de luminosidade de $100,71,45,25,9,6$ e $2 \%$ de luz plena do dia, Inoue \& Torres (1980) verificaram que as plantas crescendo entre 9 e $25 \%$ apresentaram maior altura, enquanto que a maior produção total de matéria seca foi alcançada em plantas sob céu aberto e sob 71 e $45 \%$. 
Com o objetivo de estudar o comportamento silvicultural quanto ao crescimento e aspecto morfológico de mudas de Cedrela fissilis Vell., Souza (1981) observou que em condições de viveiro a espécie mostrou sensível dependência à sombra, exigindo condições medianas de intensidade luminosa para um melhor desempenho no crescimento e aspecto morfológico. Também observou, quanto ao aspecto de sobrevivência, que plantas oriundas de baixas condições de luz apresentam um baixo índice de sobrevivência no terreno e neste, a sobrevivência é maior quando a intensidade de luz é menor, independente do vigor da muda. O incremento das mudas aos 6 meses é independente das condições de luz no terreno. A maior resposta do Cedro para crescimento em altura foi de $25 \%$ de luminosidade relativa. A incidência da broca do Cedro ocorreu tanto em campo aberto quanto nas linhas de enriquecimento, sendo constatada uma maior freqüência nas linhas mais estreitas.

Estudos a respeito da influência da irradiação sobre a fotossíntese, morfologia e desenvolvimento de plântulas de Garcinia mangosnana $L$ desenvolvidos na Austrália durante dois anos, revelaram que plântulas, submetidas ao desenvolvimento em ambiente com sombreamento decrescente, exibiam decréscimo no tamanho das folhas, incremento na espessura das folhas, baixa área foliar especifica (SLA) e alta freqüência de abertura estomatal. As plântulas menos sombreadas mostraram alocação relativamente maior de matéria seca nas raizes que as mais sombreadas e exibiam significativa redução na área foliar relativa ao total da planta, incremento no número de folhas, enlaçamento de galhos e internódios menores, resultando uma aparência mais compacta nas menos sombreadas (Wiebel et alii, 1994).

Existem grandes diferenças quanto ao potencial de desenvolvimento entre as espécies arbóreas neotropicais. Os resultados de pesquisa desenvolvida com espécies neotropicais arbóreas de mangue por Mckee (1995), avaliando suas respostas à luz e nutrientes, mostraram que existem diferenças substanciais no potencial de desenvolvimento, aquisição de recursos, tolerância a stress e suscetibilidade à herbivoria durante o estádio de 
plântulas, mas que estas características são modificadas significativamente pela avaliação de pesquisas.

Todas as três espécies arbóreas de floresta tropical conduzidas em experimento sobre resposta a diferentes intensidades de luz mostraram incremento no desenvolvimento com o aumento da radiação fotossinteticamente ativa (PAR), segundo Turner (1989).

As espécies tropicais se diferenciam umas das outras muito mais em seu desenvolvimento que em suas taxas fotossintéticas, e isto leva a concluir que a distribuição de assimilados tem sido melhor diagnosticada pelo status ecológico das espécies que pela taxa de produção de assimilados por área foliar, segundo ensaio desenvolvido com plântulas de quatro espécies arbóreas neotropicais por Ramos \& Grace (1990).

Existe uma relação linear fundamentada entre matéria seca radicular e intensidade de luz em Larix occidentalis, observada por Vance \& Running (1985).

O desenvolvimento prévio não afetou a resposta de desenvolvimento presente em D. panamensis e H. appendiculatus em pesquisa desenvolvida por Fetcher et alii (1983), sobre o efeito de diferentes intensidades de luz, quando as duas espécies exibiram respostas positivas em desenvolvimento com o incremento da irradiação.

\subsection{Déficit Hídrico}

Os fatores ambientais, em seu conjunto, são fundamentais ao desenvolvimento das espécies vegetais arbóreas. No caso de florestas mesófilas semidecíduas encontradas em regiões que apresentam déficit hídrico no período da seca, o fator água disponível no solo é fundamental tanto para a sobrevivência quanto para o desenvolvimento destas espécies.

Sob um bosque em crescimento, a competição das raízes reduz substancialmente a quantidade de umidade do solo disponíveis para as plântulas do subbosque. A combinação do tamanho reduzido das raizes e a pouca umidade do solo é 
frequentemente fatal às plântulas. $\mathrm{O}$ fato que, sob dossel florestal, tanto a luz como a umidade do solo serem reduzidas, mostra um pouco sem sentido de relacionar a irradiação relativa de luz para sobrevivência e crescimento das plantas de sub-bosque sob condições controladas. As curvas mostrando o efeito da radiação de luz sobre o desenvolvimento das plantas do sub-bosque ignoram a existência de variações na umidade do solo e outros fatores do meio ambiente que são também variáveis sob diferentes densidades do dossel (Spurr 1980).

A influência da disponibilidade de água no solo e da intensidade de luz para o desenvolvimento de plântulas de Fagus sylvatica apresentaram incremento no desenvolvimento e decréscimo na relação raiz/galhos em solos com alta disponibilidade de água e com aumento da intensidade de luz. Em solos com baixa disponibilidade de água, tanto o desenvolvimento quanto a relação raiz/galhos apresentaram baixo incremento com o incremento da intensidade de luz. A quantidade de água no solo também é afetada pela intensidade de luz, indicando que o conteúdo de água no solo pode ter causado efeitos não observados na resposta pelo incremento de luz em investigações anteriores (Madsen, 1994).

As respostas de Fagus sylvatica também foram observadas por Tognetti et alii (1994) em diferentes regimes de água, quanto ao seu desenvolvimento em diferentes intensidades de luz. O estresse hídrico causou declínios significativos na taxa líquida de fotossíntese e na condutância foliar tanto nas plantas desenvolvidas à sombra quanto nas testemunhas. A taxa líquida de fotossíntese não foi completamente recuperada no tratamento de plantas desenvolvidas à sombra sob estresse hídrico durante trinta dias de exposição a altas irradiações.

Em estudos realizados com plântulas de Quercus petraea e Nothofagus procera, Igboanugo (1988) concluiu sobre a transpiração de plantas, que folhas expostas a pleno sol são melhor adaptadas ao déficit hídrico que folhas sombreadas.

Analisando as respostas de Acer platanoides sobre alocação de água em cloroplastos, as folhas expostas ao sol continham uma quantidade de 1,7 vezes mais água por unidade de área que as expostas à sombra. Os cloroplastos continham $17 \%$ do total da água da folha 
em folhas expostas ao sol e $47 \%$ do total de água em folhas sombreadas. Comparando iguais superficies de área, os cloroplastos de folhas sombreadas contiveram aproximadamente 1,6 vezes mais água que cloroplastos de folhas expostas ao sol (Mccain et alii, 1988).

Foi observado que plântulas de Larix occidentalis desenvolvidas à sombra, quando submetida a estresse hídrico demonstraram significativa redução diurna na condutância foliar, e as submetidas ciclos de estresse hídrico e oferta de água, mostraram adaptação ao estresse (Vance \& Running, 1985).

Segundo Bazzaz \& Pickett (1980), os períodos secos em florestas tropicais são mais comuns do que se pensa ocorrer e a morte de plântulas em larga escala de algumas espécies em florestas maduras ocorre mesmo durante períodos curtos de seca.

\subsection{Temperatura}

No sub-bosque, a variação diária da temperatura pode ser pequena e temperaturas das folhas podem permanecer próxima à temperatura do ar, exceto em clareiras(Bazzaz \& Pickett ,1980).

As temperaturas do solo da floresta podem diferir pouco da temperatura do ar, mas em clareiras são significativamente mais elevadas durante o dia. A variação máxima diária ocorre na superficie a dois centímetros de profundidade. A temperatura do solo em clareira pode variar de $25^{\circ} \mathrm{C}$ à noite a $42{ }^{\circ} \mathrm{C}$ durante o dia, segundo os mesmos autores.

Em trabalho de pesquisa desenvolvido na Floresta Nacional do Jamarí - RO, França \& Poggiani (1994) observaram que no interior de todas as áreas a temperatura do ar,

nas horas mais quentes do dia gira ao redor de $30^{\circ} \mathrm{C}$, ou seja, $7{ }^{\circ} \mathrm{C}$ abaixo da temperatura do ambiente exterior e a temperatura da camada superficial do solo acompanha de perto a temperatura do ar. 


\subsection{Fenologia}

Em florestas decíduas há grandes diferenças estacionais na quantidade de luz do dia que consegue atingir as camadas mais baixas. Sabe-se que nestas florestas, algumas espécies da camada junto ao solo estão adaptadas a estas condições e realizam todo o seu crescimento estacional antes que as folhas novas das árvores situadas acima delas se expandam totalmente na primavera ( Whatley \& Whatley, 1982).

As fenofases em florestas mesófilas semidecíduas são fatores fundamentais no tocante à disponibilidade de luz sob seu dossel e consequentemente influenciam na germinação e desenvolvimento de sementes, plântulas e estados juvenis de espécies arbóreas. A fenologia de oito diferentes florestas tropicais (sob duas estações, uma fraca outra forte) dão consistência à hipótese de que a produção de folhas e flores teria sido selecionada para coincidir com a estação de pico de irradiação (Wright et alli, 1994).

Em trabalho de pesquisa realizado por Salis \& Mattos (1993) sobre fenologia de espécies arbóreas nativas com potencial madeireiro na sub-região da Nhecolândia, Pantanal do Mato Grosso, observou-se que as características fenológicas encontradas foram relacionadas à sazonalidade do clima. O clima da região estudada é Aw com a estação seca ocorrendo em geral de junho a agosto e as chuvas mais intensas de novembro a fevereiro. $\mathrm{O}$ angico (Anadenanthera macrocarpa) bem como outras espécies apresentaram no final da seca, queda total das folhas. O brotamento ocorreu em todas as espécies na estação chuvosa. A floração das espécies não foi coincidente, ocorrendo desde a estação seca à chuvosa. A frutificação da maioria das espécies se deu no final da estação seca e início da chuvosa.

O pico de queda de folhas em duas florestas, sendo uma delas floresta mesófila, estudadas por Morellato(1992), ocorreu no final da estação seca (agosto/setembro), decaindo em outubro-novembro. Esta maior produção de serapilheira nas duas formações florestais da Serra do Japi, durante a estação seca, também foi registrada por outros autores trabalhando em floresta de terra firme na Amazônia e em 
outras florestas mesófilas semidecíduas do Estado de São Paulo (Cesar, 1988; Pagano, 1985; Poggiani \& Monteiro Júnior, 1990). Durante a estação seca, a pequena disponibilidade hídrica e as baixas temperaturas influenciam as espécies, estimulando a queda de folhas e deiscência e ou dispersão de diásporos anemocóricos. A diminuição da água no solo dificultaria a tomada de nutrientes e a maioria das espécies perderia suas folhas, diminuindo assim a evapotranspiração.

De maneira geral, segundo a mesma autora, com o aumento da temperatura e as primeiras chuvas, a partir de agosto e setembro, acelera-se o processo de decomposição da serapilheira acumulada, tornado os nutrientes disponíveis para a vegetação, que entra no seu período de maior atividade reprodutiva e vegetativa, delimitando-se uma primavera tropical. Também esta maior disponibilidade de nutrientes pode estar influenciando o período de frutificação. Embora haja frutos disponíveis durante todo o ano, a maior quantidade de frutos carnosos ou arilados ocorre no início da estação úmida, de outubro a dezembro.

\subsection{Fragmentos}

A fragmentação florestal no Estado de São Paulo é um dos fenômenos mais marcantes no processo de ocupação e uso do solo desordenado, uma vez que não só nos deparamos com a redução da cobertura natural vegetal, mas também com o isolamento, e pulverização e grandes alterações estruturais das áreas remanescentes, trazendo conseqüências graves. Segundo Viana et alii (1992), o aspecto mais grave da fragmentação florestal é a perda de biodiversidade tanto animal quanto vegetal. Estudos desenvolvidos pelo mesmo autor na região de Piracicaba indicam que a maioria dos fragmentos são pequenos e isolados, onde a ocorrência de cipós em alta densidade dificulta a regeneração natural de espécies arbóreas, sendo a freqüência de árvores mortas alta, o efeito de borda é significativo e complexo e os fragmentos necessitam de manejo para evitar o prosseguimento do processo atual de degradação e perda da biodiversidade. 
Um dos mais importantes fatores de pressão sobre os fragmentos é o efeito de borda: a partir da linha divisória da vizinhança para dentro do fragmento forma-se um gradiente de influências dos fatores ambientais do meio externo (vizinho), promovendo uma série de modificações na estrutura e dinâmica do mesmo, no sentido de sua borda para o interior. Com o intuito de dimensionar o efeito de borda sobre a vegetação arbórea e fazer uma relação desta com a sustentabilidade do fragmento florestal, Waldhoff \& Viana (1993) observaram que existia uma degradação estrutural em até pelo menos $50 \mathrm{~m}$ da borda, onde observaram maior predominância de cipós e altura média menor das árvores com relação ao encontrado no interior do fragmento. Como agentes principais do efeito de borda, apontaram a ação do vento, aumento da luminosidade e eventual passagem de fogo.

O conhecimento a respeito da ecologia de populações das espécies arbóreas tropicais é fundamental para o entendimento da dinâmica funcional das florestas nativas. Entre os pontos mais importantes para o entendimento da dinâmica funcional das florestas tropicais, destaca-se a sucessão secundária (Gomes-Pompa, 1971).

Este processo dinâmico foi subdividido por Budowski (1965) para as florestas neotropicais em quatro fases ou séries sucessionais distintas, as quais denominou de floresta pioneira, secundária inicial, secundária tardia e floresta clímax. Segundo o autor, as espécies componentes de cada fase apresentavam um conjunto de características comuns e lhes atribuiu funções diferenciadas dentro do processo sucessional, como se fossem grupos funcionais distintos. Didaticamente, estas teorias são muito importantes, pois permitem a percepção e a caracterização das comunidades que compõem cada fase, bem como a compreensão da função ecológica de cada espécie. Outros autores, como Hallé et alii, (1978), incluem muitas fases intermediárias neste processo, como parte fundamental de um processo maior de silvagenese, formando um contínuo sucessional que pode variar conforme a história de vida de cada comunidade, o que torna o processo de sucessão secundária mais complexo do que o proposto por Budowski (1965).

Um fator fundamental para se iniciar entendimentos sobre os complexos ecossistemas de florestas neotropicais é o conhecimento da sua história de perturbações e 
dinâmica sucessional. Clark \& Clark (1992), estudando a história da diversidade das copas de florestas neotropicais, chegaram a resultados que mostram que para espécies tropicais não pioneiras, a classificação da história de vida baseada em conceitos generalizados sobre a dependência de clareiras e tolerância a sombra é inadequada para descrever um complexo padrão de história de vida das diferenças e similaridades entre as espécies.

A floresta tropical úmida, sem interferência humana, apresenta uma dinâmica própria de renovação constante com mortalidade e ingressos, fazendo com que a sua biomassa flutue constantemente em função do tempo, concluem Jesus et alii (1992). Trabalhando com vários níveis de intervenções na floresta, observaram que os tratamentos que envolvem o corte de limpeza apresentaram crescimentos inferiores e mortalidade superior aos sem esta prática. Os tratamentos que foram submetidos às altas intensidades de corte apresentaram menor recuperação em relação aos valores originais do povoamento. Sob o ponto de vista ambiental e da sustentabilidade da produção florestal, recomenda-se a retirada de $15 \%$ da área basal original da floresta a partir das árvores de maior diâmetro, por ter apresentado a mais rápida cicatrização, não apresentando invasão de espécies indesejáveis e permitindo nova exploração após 10 anos.

No ciclo de vida de uma árvore, as etapas de plântula e estado juvenil são de grande importância. O estado juvenil tem sido definido como o estado que se segue a independência da plântula das reservas das sementes, mas que precede o estado vegetativo adulto e a produção de flores e sementes. A maioria das pesquisas sobre mortalidade e sobrevivência de plântulas e estados juvenis de árvores tem sido realizadas em bosques temperados e em grandes proporções sob condições controladas, tentando reproduzir condições naturais (Amo \& Gómez-Pompa,1979). Os mesmos autores têm claro que o papel das plântulas e estados juvenis de árvores no sub-bosque' da selva equivale ao das sementes das árvores primárias nos solos de bosques temperados. Os estados de plântulas e plantas jovens constituem o principal potencial de regeneração permanente. $\mathrm{O}$ enriquecimento de fragmentos florestais remanescentes nestes dois estágios com espécies nativas com potencial silvicultural poderá significar ao mesmo tempo uma contribuição à 
biodiversidade e fonte de recursos para os agricultores que preservarem seus fragmentos em busca da sustentabilidade das suas atividades agroflorestais.

\subsection{Espécies Arbóreas Nativas com Utilização Silvicultural e Enriquecimento}

A indicação de essências nativas potenciais, que sirvam como alternativas ao reflorestamento, está limitada por falta de informações sobre adaptação ecológica e o comportamento silvicultural das espécies em ensaios de comparação, segundo Carvalho(1982). Conforme o mesmo autor, as espécies potenciais são as que apresentam as seguintes características: valor econômico comprovado, com produção de madeira valiosa; desempenho silvicultural aceitável; aptidão para programas de regeneração artificial. Também apresenta uma relação das espécies com maior quantidade de informações, estando entre elas, algumas de ocorrência em nossa região, como o "angico-vermelho" (Parapiptadenia rigida (Benth.) Bren); "pau jacaré" (Piptadenia gonoacanta (Mart) Macbr.), "araribá rosa" - (Centrolobium robustum (Vell.) Mart. ex Benth); "ipê roxo" (Tabebuia avellanedae Lorentz ex Grisebach); "tamboriu” (Enterolobium contortisiliquum (Velozo) Morong)

Molas \& Pretzcsch (1989) afirmam que o enriquecimento em faixas pode constituir-se em uma das alternativas mais viáveis para manejar as florestas nativas degradadas no Paraguai. Segundo os autores, o método oferece vantagens comparativas frente ao reflorestamento, especialmente pelo baixo custo de investimento inicial requerido, a maior qualidade da madeira produzida e porque sua execução afeta muito pouco o ambiente natural.

Com o objetivo de determinar o crescimento e sobrevivência de dezessete espécies florestais em três sítios diferentes, plantadas pelo método de linhas de enriquecimento, sobre áreas de florestas degradadas, empregando-se delineamento em blocos ao acaso, efetuou-se análise de variância para as variáveis diâmetro, altura total e 
sobrevivência, encontrando-se diferenças estatísticas entre as espécies para cada um dos sítios nas variáveis estudadas (CONIF, 1986).

Martins et alii (1990), trabalhando com espécies florestais nativas de interesse madeireiro e frutífero em plantio de enriquecimento em área de mata nativa degradada, objetivando obter informações sobre o desempenho silvicultural de algumas espécies plantadas em linhas abertas a cada 4 metros, com mudas distribuídas aleatoriamente em espaçamentos 4 × 4 metros, com 8 repetições de 12 mudas, trabalhando em duas áreas, com 8 e 10 espécies, observaram diferença significativa para altura entre as plantadas nas duas áreas e para o DAP, observaram diferenças significativas somente no plantio da primeira área. $\mathrm{O}$ autor concluiu que as espécies timburi, canafistula e o angico obtiveram crescimento rápido. A gurucais, aroeirinha, jatobá, cedro e louro pardo obtiveram crescimento médio. Já a canela-imbuia e a peroba mostraram crescimento muito lento.

Em ensaio com 56 espécies nativas, para estudos de enriquecimento em matas degradadas e em formação de menor potencial, Jesus et alii (1982) faz considerações iniciais sobre o comportamento de cada espécie, como sobrevivência e desenvolvimento das mudas.

Desenvolvendo trabalho experimental com "araribá amarelo" (Centrolobium tomentosum Benth), Gurgel Filho et alii (1982a) afirma ser a espécie de valor silvicultural comprovado, com incrementos volumétricos de $15 \mathrm{~m}^{3} / \mathrm{ha} / \mathrm{ano}$, podendo evoluir para $20 \mathrm{~m}^{3} / \mathrm{ha} /$ ano.

O "iibirá puitá" (Peltophorum vogeliamum Benth), que teve seu estudo silvicultural abrangendo um período de 26 anos, revelou-se uma espécie viável do ponto de vista econômico e de crescimento vigoroso, segundo Gurgel Filho et alii (1982a).

O "jatobá" (Himenaea stilbocarpa Hayne), embora tenha demonstrado crescimento inicial lento, é indicado para povoamentos sob fragmentos ou consorciados á agricultura e teve incremento volumétrico a razão de até $9 \mathrm{~m}^{3} / \mathrm{ha} / \mathrm{ano}($ Gurgel Filho et alli (1982b). 
O "pau-ferro" (Caesalpinea leiostachya (Benth.) Ducke), também se mostra promissor, com crescimento rápido e homogêneo, com incremento volumétrico potencial de $15 \mathrm{~m}^{3} / \mathrm{ha} /$ ano, (Gurgel Filho et alii, 1982a).

Também conduzindo ensaios sobre competição entre várias espécies em povoamentos puros bem como suas características silviculturais, relatam que aos 14 anos, o maior crescimento em altura e volume foi alcançado pelo jequitibá vermelho (Cariniana legalis (Mart) O. Ktze), seguido pelo guarantã. O óleo de copaiba e "peroba rosa" não apresentaram diferenças significativas. A "peroba" apresentou o menor crescimento em altura.

\subsection{Instalação de Experimentos.}

Os trabalhos de pesquisa implementados para estudos de autoecologia de espécies arbóreas nativas no Brasil em seus estágios iniciais de desenvolvimento é relativamente recente, com poucos trabalhos desenvolvidos em campo, no meio natural. Basicamente, os estudos têm sido desenvolvidos em maior quantidade em laboratórios, como Barbosa(1980) estudando o angico e déficit hídrico e em viveiros; como Engel \& Poggiani (1990) e Poggiani et alii (1992) estudando efeitos do sombreamento em mudas de espécies arbóreas nativas. Também o cultivo a pleno sol foi estudado por Gurgel Filho et alii(1982a); plantio em linhas de enriquecimento em florestas, como Jesus et alii (1982); CONIF(1986); Molas \& Pretzcsch(1989); Martins(1990), cultivo em trilhas de arraste e clareiras Oliveira(1996), e cultivo sob dossel florestal, como Davide et alii (1996) com plantio em sub-bosque de Eucaliptus.

Em trabalhos desenvolvidos sob condições controladas como laboratórios, estufas e viveiros torna-se muito mais fácil o isolamento do parâmetro que se deseja estudar, permitindo melhor controle local das variáveis indesejáveis, permitindo grande precisão aos experimentos. Mas estes dados quando extrapolados para o campo podem não condizer com o que realmente ocorre nas condições naturais, perdendo confiabilidade. Os 
cultivos a pleno sol permitem o controle de menos fatores, dificultando um pouco o controle local, mas as condições se aproximam mais das encontradas no ambiente natural, principalmente das clareiras grandes. Por outro lado, os ensaios com cultivo de exemplares de espécies arbóreas sob condições naturais são mais trabalhosos de serem instalados, conduzidos e observados, não permitindo na maioria das vezes um bom controle local, reduzindo a precisão do ensaio, levando muitas vezes ao trabalho com coeficientes de variação elevados e heterogêneos, mas promovendo maior confiabilidade pelos dados terem sido obtidos no meio de ocorrência natural da espécie.

$\mathrm{Na}$ instalação dos ensaios, o número de indivíduos observados por parcela é muito importante, pois quanto maior, menores serão os desvios e mais precisas serão as médias, mas maiores serão as áreas experimentais e as dificuldades de instalação e acompanhamento em condições de campo. A grande maioria dos ensaios é montada com um número elevado de indivíduos por parcela, representando algumas dezenas dos quais uma parcela é deixada para reduzir efeitos de borda e outra para medições dos parâmetros estipulados para pesquisa. Existe porém uma metodologia utilizada por Oliveira(1996) que consiste em utilizar uma planta por parcela em sistema denominado "one tree plot", que facilita a instalação de ensaios, principalmente em ensaios comparativos do comportamento de desenvolvimento de mudas em diferentes condições microclimáticas dentro da floresta, comp em clareiras de diversos tamanhos, sob dossel, em áreas drenadas e inundadas e mesmo combinando mais de um fator a ser estudado. 


\section{MATERIAL E MÉTODOS}

\subsection{Localização e Características Ambientais}

O trabalho experimental foi instalado em campo, na Usina Hidroelétrica de São Joaquim, localizada no município de Guará, Estado de São Paulo, situada a $20^{\circ}$ $34^{\prime}$ de latitude sul e $47^{\circ} 47^{\prime}$ de longitude oeste, com $600 \mathrm{~m}$ de altitude, demonstrado pela figura 1(Brasil 1, 1972).

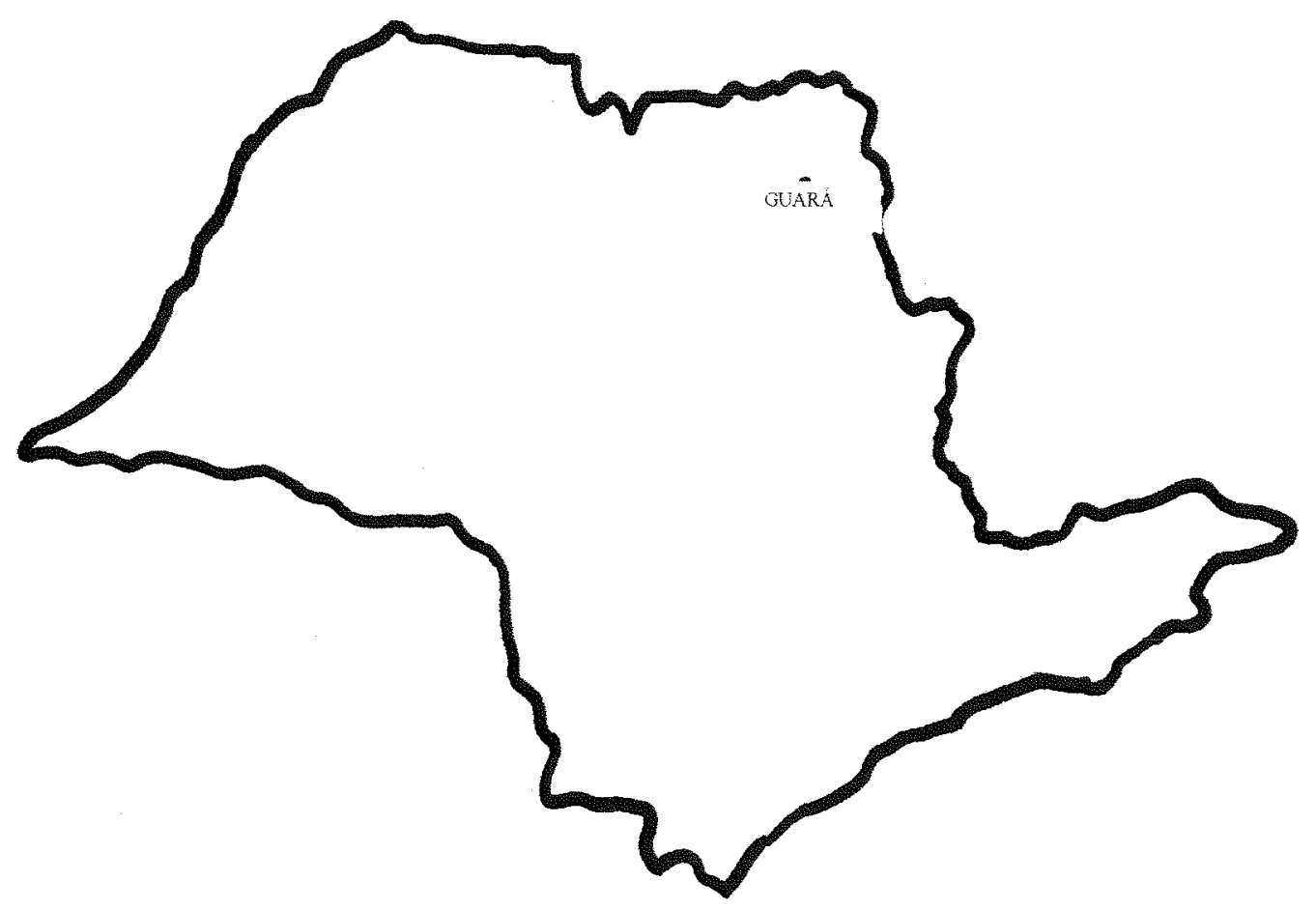

Figura 1 - Lacalizaça da área experimental no estado de São Paula. 


\subsubsection{Clima}

O clima é Aw, tendo verão úmido e inverno seco, segundo classificação de Koeppen.

A temperatura média mensal representando o período de $1943-70$ e os anos de 1995 e 1996, constam na tabela 1(IAC, 1997).

Tabela 1- Temperatura média mensal da regiãa de Ribeirãa Preta.

\begin{tabular}{llcc}
\hline MÉS & 1995 & 1996 & $1943 / 1970$ \\
\hline JAN & 25,5 & 25,2 & 23,3 \\
FEV & 24,6 & 25,7 & 23,3 \\
MAR & 24,8 & 24,9 & 22,9 \\
ABR & 22,8 & 23,3 & 21,3 \\
MAI & 20,7 & 20,3 & 19,2 \\
JUN & 19,7 & 18,9 & 18,2 \\
JUL & 21,3 & 19,0 & 18,3 \\
AGO & 23,6 & 21,6 & 20,5 \\
SET & 24,0 & 22,2 & 22,6 \\
OUT & 23,4 & 24,4 & 23,0 \\
NOV & 23,9 & 23,7 & 23,2 \\
DEZ & 24,7 & 24,5 & 23,3 \\
\hline ANO & 23,25 & 22,55 & 21,6 \\
\hline
\end{tabular}

Fonte: " IAC (1997).

Verifica-se que a temperatura no período em que o ensaio experimental estava montado foi superior à média histórica, por representar média de um período menor, sendo menos precisa. A ocorrência de geadas na região foi observada nas áreas mais baixas, mas não é fenômeno comum, sendo de ocorrência esporádica. Percebe-se pequena variação na temperatura média ao longo do ano.

As precipitações pluviais totais do período de 1943-70 e de 1995 e 1996, estão representadas na tabela 2.

\footnotetext{
* Dados não publicados, fornecidos pela Seção de Climatologia do IAC, Campinas, SP.
} 
Tabela 2 - Precipitação plumiométrica total em mm da reqião de Ribeirão Preto

\begin{tabular}{lccc}
\hline MES & 1995 & 1996 & $1943 / 1970$ \\
\hline JAN & 203,8 & 244,1 & 283,0 \\
FEV & 409,4 & 175,2 & 216,0 \\
MAR & 105,8 & 172,2 & 169,0 \\
ABR & 104,5 & 53,1 & 61,0 \\
MAI & 79,0 & 59,4 & 45,0 \\
JUN & 19,3 & 23,0 & 29,0 \\
JUL & 18,6 & 0,0 & 17,0 \\
AGO & 0,9 & 24,7 & 15,0 \\
SET & 36,3 & 116,6 & 40,0 \\
OUT & 126,2 & 188,1 & 130,0 \\
NOV & 83,1 & 229,1 & 162,0 \\
DEZ & 258,8 & 23,0 & 254,0 \\
\hline ANO & 1440 & 1308 & 1416 \\
\hline
\end{tabular}

Fonte: IAC(1997).

A interação dos parâmetros temperatura média mensal e precipitação nos mostra o balanço hídrico da região, através da Figura 2 .
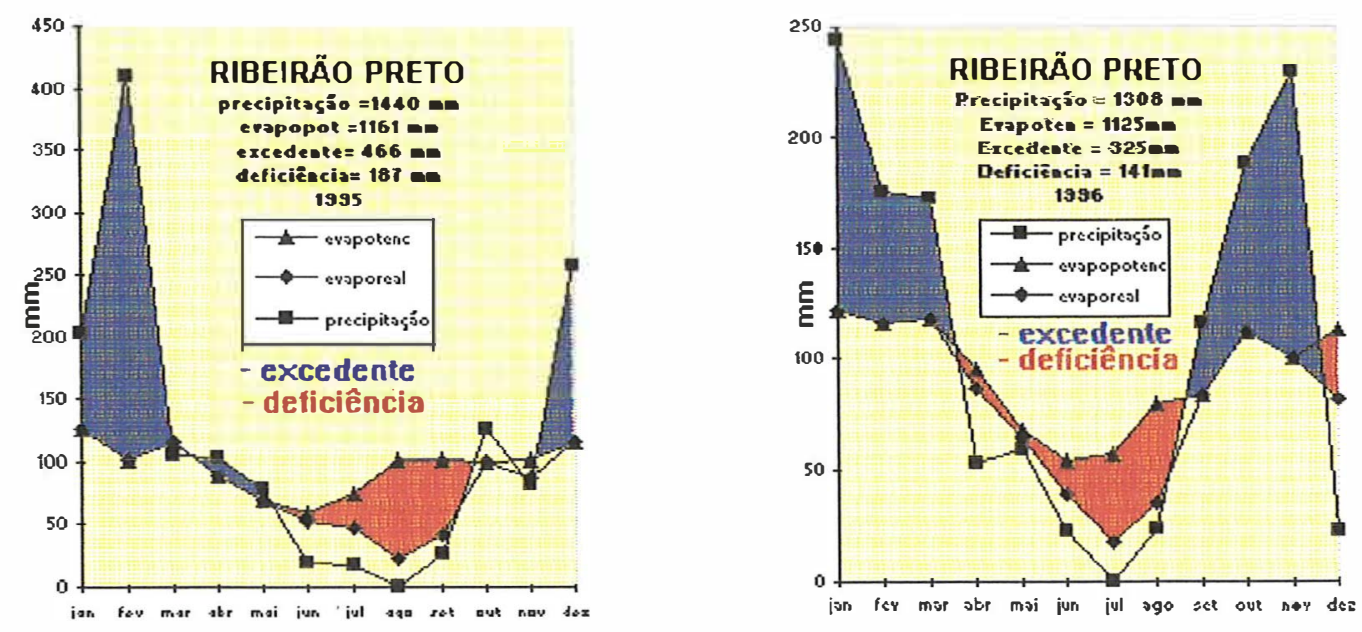

Fiquna 2 - Balanca hidrica da regiãa de Ribeinão Preta dunante as anad de 1995 e 1996.

\footnotetext{
* Dados não publicados, fornecidos pela Seção de Climatologia do IAC, Campinas, SP.
} 
Percebe-se um déficit hídrico acentuado de maio a setembro de 1995 $(187 \mathrm{~mm})$ e de março a setembro e em dezembro de $1996(141 \mathrm{~mm})$, sendo este último caracterizado como veranico.

A radiação solar global média na região, atinge sua maior intensidade no mês de janeiro, com $521 \mathrm{CAL} . \mathrm{cm}^{-2}$. dia ${ }^{-1}$, e sua menor intensidade no mês de junho, com 356 CAL. $\mathrm{cm}^{-2}$. dia ${ }^{-1}$, segundo Pedro Júnior et alii (1989).

A insolação média diária em horas por dia na região é maior nos meses de abril e agosto $(7,9 \mathrm{~h} / \mathrm{d})$ e menor nos meses de dezembro $(6,1 \mathrm{~h} / \mathrm{d})$, janeiro $(6,7 \mathrm{~h} / \mathrm{d})$ e fevereiro (6,8 h/d), segundo * IAC (1997).

\subsubsection{Vegetação:}

A área de estudo é constituída por fragmento florestal nativo da floresta tropical mesófila latifoliada semidecídua de planalto em estádio médio de regeneração, sendo classificado segundo DPRN (1993) como capoeira, podendo ser observada parte da mesma através da figura 3.

Segundo dados do Ministério das Minas e Energia (1983), a vegetação florestal da região encontra-se em uma área de tensão ecológica, num contato entre cerrado e floresta estacional. O contato entre regiões fitoecológicas se faz através da interpenetração de seus ambientes, caracterizando um ecotono (mistura de espécies) ou enclave de pequenos grupamentos florísticos bem caracterizados.

A ocorrência de lianas de várias espécies é observada em todo o fragmento. As espécies não têm distribuição uniforme. As espécies secundárias, que em florestas primárias ocorrem em pequena freqüência, dominam em grande quantidade, principalmente o angico e a aroeira. Por ser fragmento em regeneração, o dossel possui poucos extratos, embora densos.

\footnotetext{
* Dados não publicados, fornecidos pela Seção de Climatologia do IAC - Campinas, SP
} 


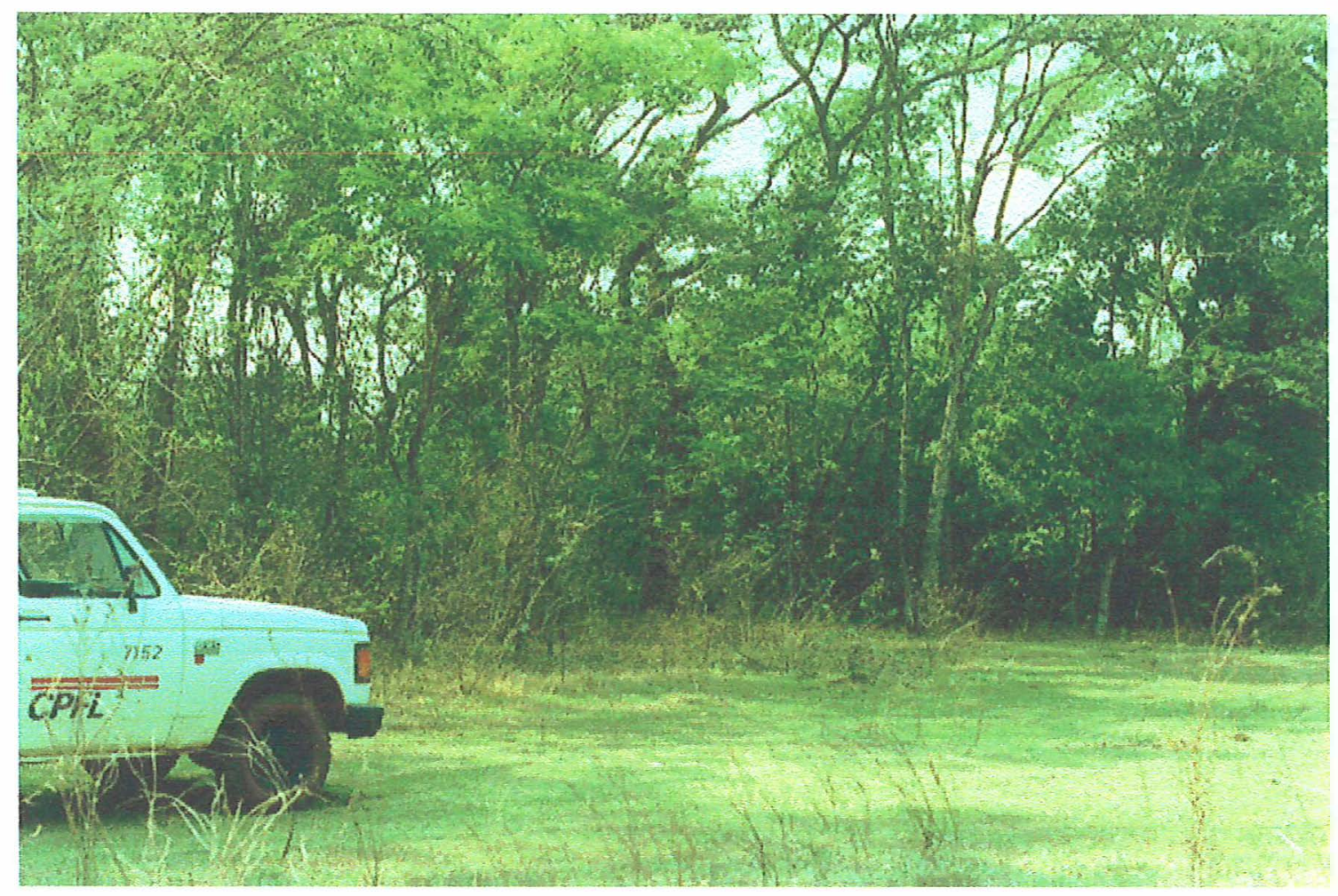

Figura 3 - Nustraçãa de parte da borda do fragmenta onde a ensaia foi instalada.

Existem espécies arbustivas e arbóreas dos vários grupos sucessionais, predominando espécies do grupo secundário, como angico- Piptadenia spp, guatambú Aspidosperma spp, jequitibá branco - Cariniana estrelensis, óleo de copaíba - Copaífera langsdorfii, aroeira - Myracrodrum urundeuva, pau jacaré - Paraptadenia gonoacanta, ingá - Inga spp, ipê roxo - Tabebuia spp, marinheiro - Guarea guidonia (L) Sleumer), mamica de porca - Fagara spp, figueira - Ficus spp, olho de cabra - Ormosia spp, cedro rosa - Cedrela fissilis, jacarandá bico de pato - Machaerium nyctitans, farinha seca Albizia hasslerii, jenipapo - Jenipa americana, que dominam o dossel do fragmento, atingindo de 8 a $20 \mathrm{~m}$ de altura. Existem também espécies de início de sucessão (pioneiras) como a embaúba - Cecrópia sp, pau pólvora - Trema micranta, arranha-gato - Acassia paniculata e capixingui - Croton floribundıs, em menor quantidade próximo às bordas do fragmento. Também ocorrem algumas poucas espécies climácicas, como o 
jatobá - Himenaea corbaril e espécies arbustivas encontradas do sub-bosque, como as do gênero Piper spp .

O fragmento soma 15 ha, onde o ensaio foi instalado em sua parte que margeia o canal de adução de água para gerar energia elétrica na usina, possuindo em média $60 \mathrm{~m}$ de largura por $1500 \mathrm{~m}$ de comprimento, totalizando 7,5 ha. A figura 4 mostra a área experimental.

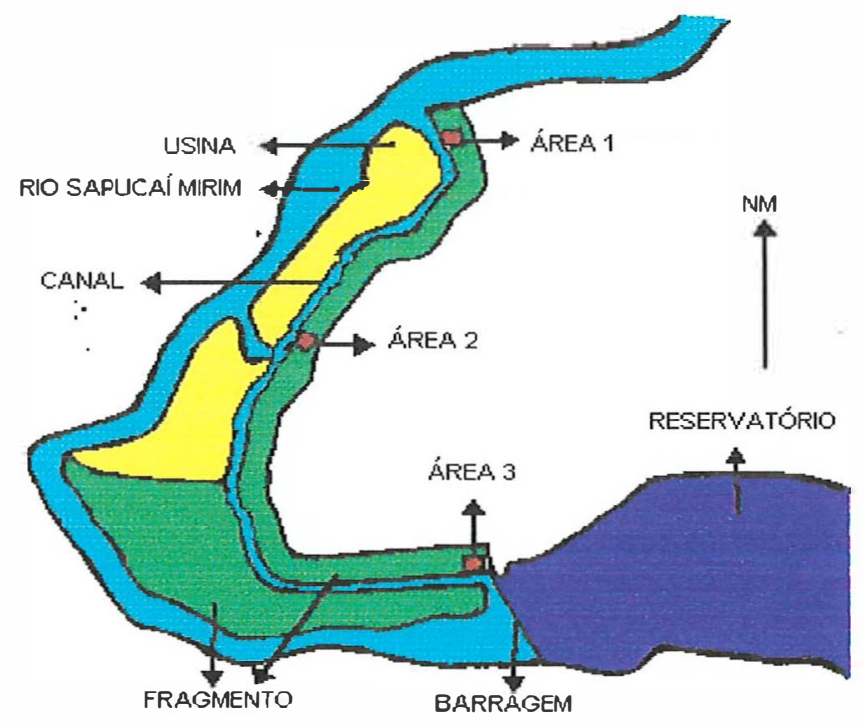

Figura 4 - Croquis da área da Usina \#idradétrica de Sãa Daaquim, mostrando a fragmenta $c$ a localizaçãa das áreas exporimentais.

\subsubsection{Relevo}

O relevo da região é caracterizado como superficies aplainadas com inclinação menor que $5^{\circ}$, levemente ondulado. As formações superficiais são espessas de 
textura argilosa e areno-argilosa aproveitadas no uso para pecuária de corte, cultivo de cana de açúcar e soja. Apresenta morfodinâmica atual apontando para propensão ao ataque de processos erosivos em determinados pontos, existindo um equilíbrio entre a morfogênese e pedogênese, sendo uma área de transição. As potencialidades e limitações de uso apontam para o reflorestamento em áreas pouco utilizadas para produção agropecuária, visando redução do processo de degradação, uma vez que atividades agropastoris generalizadas aceleram o processo de morfogênese (Ministério das Minas e Energia, 1983).

\subsubsection{Geologia}

A área encontra-se sobre a Formação Serra Geral e intrusivas básicas associadas no grupo litólico São Bento, constituída por basaltos toleíticos, cujo intemperismo resulta o latotossolo roxo, dentre outros tipos de solos.

\subsubsection{Geomorfologia}

A área encontra-se situada sobre domínio morfoestrutural da Bacia do Paraná e coberturas sedimentares, na região geomorfológica dos planaltos do Alto do Rio Paraná, na unidade geomorfológica dos Planaltos Rebaixados(Ministério das Minas e Energia, 1983).

\subsubsection{Pedologia}

Os solos predominantes na região são os classificados no grupo latossolo roxo distrófico. 


\subsection{Características do Experimento}

Com o intuito de estudar o comportamento em desenvolvimento e sobrevivência de cinco espécies florestais arbóreas nativas da região com potencial silvicultural, sob dossel de floresta nativa, foi montado um experimento no interior de fragmento, conforme ilustra figura 4 . O delineamento estatístico utilizado foi o inteiramente casualizado. Cada uma das três áreas experimentais constituiu-se por 5 tratamentos, representados por 5 espécies florestais arbóreas nativas abaixo descritas, dos grupos sucessionais secundário e climácico, segundo classificação de Budowski (1965), com nove repetições, somando 15 parcelas em cada área, distribuídas aleatoriamente, totalizando 45 parcelas, conforme figura 5 .

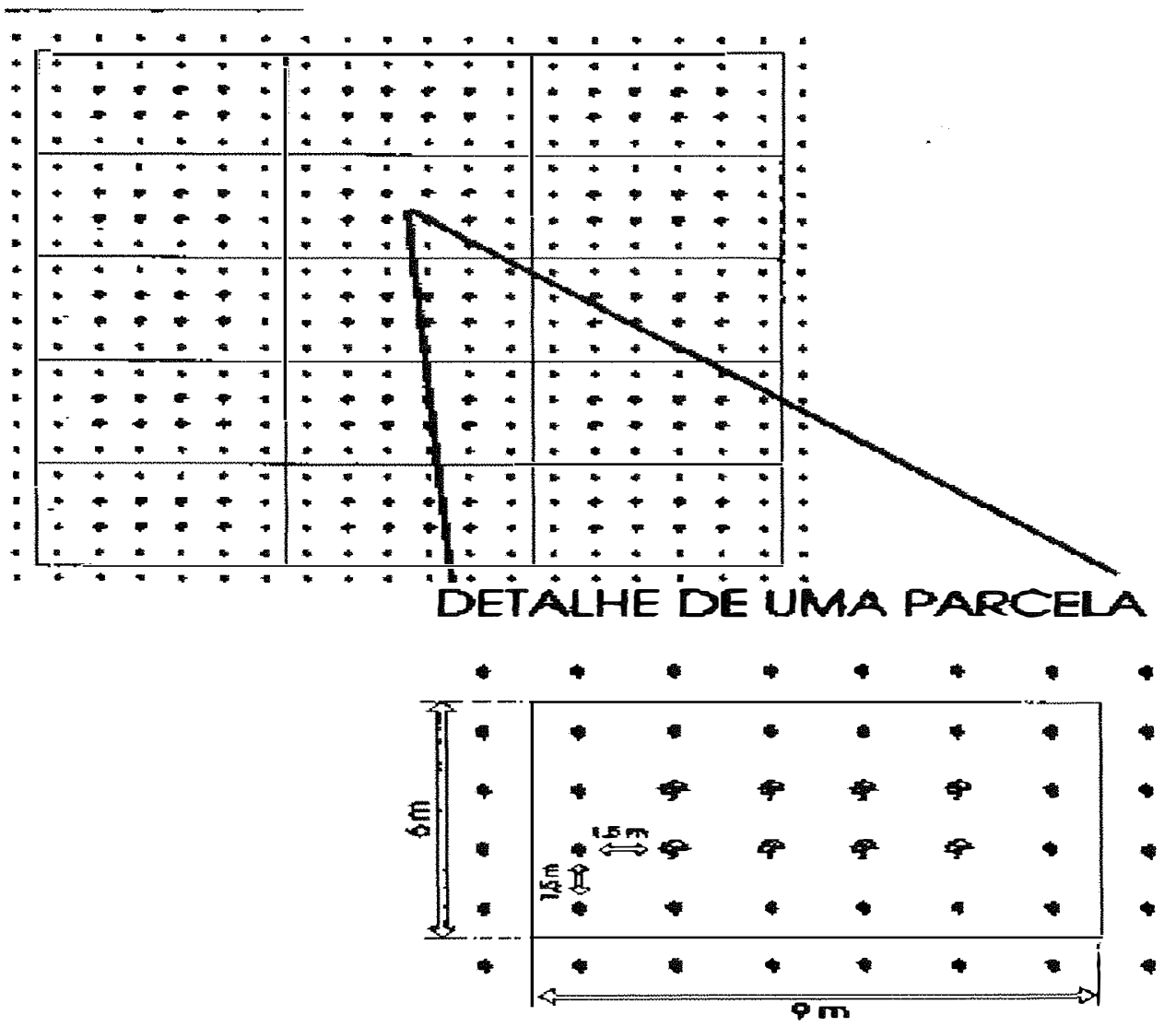

Fiqura 5 - Croquid das parcelad. 
Cada parcela foi constituída por 24 indivíduos de cada espécie, tendo sido observadas as 8 mudas centrais, constituindo-se as demais 16 como bordaduras. Nas parcelas que faceavam com o meio externo ao experimento, foi usada bordadura dupla, constituindo-se por uma linha a mais de indivíduos da espécie da parcela. Utilizouse espaçamento de $1,5 \mathrm{~m}$ entre cada muda, o que determinou um tamanho de $54 \mathrm{~m}^{2}$ para cada parcela e $897,75 \mathrm{~m}^{2}$ para cada bloco, incluindo as bordaduras externas.

A escolha das áreas para implantação do ensaio foi criteriosa. Escolheu-se área o mais homogênea possível, a fim de permitir condições ambientais semelhantes para todas as parcelas, permitindo assim um melhor controle local.

\subsection{Espécies}

As espécies foram escolhidas pela sua ocorrência natural na região onde foi montado o ensaio, pelas suas características de interesse silvicultural e pela disponibilidade de sementes.

\subsubsection{Angico-vermelho}

Anadenanthera macrocarpa (Benth.) Brenan, pertencente à familia botânica Leguminosae-Mimosoideae, possui ainda segundo Rizzini (1978) sinonímia botânica de Piptadenia macrocarpa Benth e outros nomes populares como angico, angico-preto, angico-do-campo, arapiraca, curupaí ou angico-de-casca (Lorenzi,1992).

Características morfológicas: atinge alturas entre 13-20 m, com tronco de 40-60 cm de diâmetro. Sua casca varia, conforme Lorenzi (1992) de uma forma quase lisa e clara até rugosa ou muito fissurada e preta. Seus ramos novos podem se apresentar espinhentos. Folhas compostas bipinadas, 10-25 jugos, com folíolos rígidos, com 20-80 jugos. Rizzini (1978) descreve seu pecíolo com uma conspícua glândula negra, elipsóide, cuja abertura é rimosa, localizada junto à inserção e mais algumas menores entre as últimas pinas. 
Ocorrência: Maranhão e Nordeste do País até São Paulo, Minas Gerais e Mato Grosso do Sul, principalmente na floresta latifoliada semidecídua.

Madeira: muito pesada (densidade $1,05 \mathrm{~g} / \mathrm{cm}^{3}$ ), compacta, não elástica, rija, de grande durabilidade sob condições naturais.

Utilidade: a madeira é própria para a construção civil (vigas e assoalhos) e naval, para a confecção de dormentes e para uso em marcenaria e carpintaria. A casca é rica em tanino, tendo sido largamente utilizada pelos curtumes. Floresce exuberantemente todos os anos, o que a torna muito ornamental e própria para a arborização de parques e praças. Apresenta rápido crescimento, podendo ser aproveitađa com sucesso para reflorestamentos de áreas degradadas de preservação permanente juntamente com outras espécies de nossa flora. As flores são meliferas.

Informações ecológicas: planta decídua, "pioneira", heliófita e seletiva xerófita, característica das capoeiras e florestas secundárias situadas em terrenos arenosos e cascalhentos. Comum também no interior de mata primária densa, tanto em solos argilosos e férteis como em afloramentos basálticos. É bastante freqüente nos chamados cerradões e matas de galeria de todo o Brasil Central. Ocorre preferencialmente em terrenos altos e bem drenados, chegando a formar agrupamentos quase homogêneos. Produz anualmente grande quantidade de sementes viáveis.

Fenologia: floresce durante os meses de setembro-novembro com a planta quase totalmente despida da folhagem. Os frutos (vagens), amadurecem em agosto-setembro.

O desenvolvimento das plantas em campo é bastante rápido, alcançando facilmente 5-6 m de altura aos 2 anos, de acordo com Lorenzi (1992). A figura 6 exibe exemplar juvenil da espécie plantado sob dossel do fragmento na área experimental. 


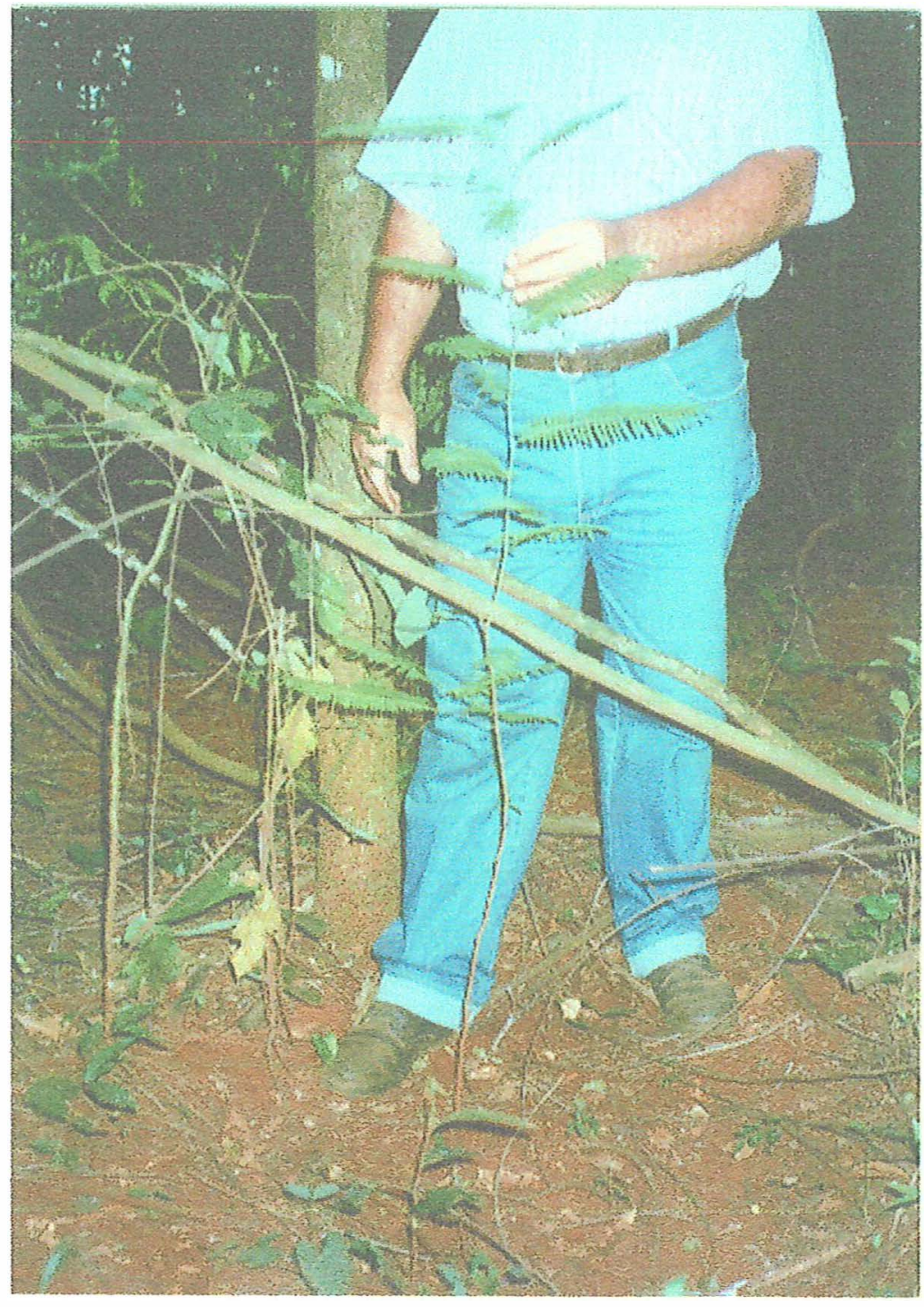

Bigura 6 - Tuarnaç̃a de muda de Angiea Vermelha. 


\subsubsection{Cedro-Rosa}

Cedrela fissilis Vell., pertencente à família Meliaceae, possui ainda sinonímia popular de cedro, cedro-vermelho, cedro-branco, cedro-amarelo e cedro de várzea.

Características morfológicas: a altura foi relatada por Lorenzi(1992) como sendo de 20-35 m, com tronco de 60-90 cm de diâmetro. Folhas compostas de 60-100 cm de comprimento, com folíolos de 8-14 cm de comprimento. Existem outras duas espécies do gênero, mas a $\mathrm{C}$. fissilis Vell. distingue-se pela pubescência da página inferior dos folíolos, pela falta de domácias e pelos frutos maiores, segundo Rizzini (1978).

Ocorrência: Rio Grande do Sul até Minas Gerais, principalmente nas floresta semidecídua e pluvial atlântica. Ocorre porém em menor intensidade em todo o país.

Madeira: leve a moderadamente pesada (densidade média de 0,55 $\left.\mathrm{g} / \mathrm{cm}^{3}\right)$, macia ao corte e notavelmente durável em ambiente seco. Quando enterrada ou submersa apodrece rapidamente. O alburno é branco ou rosado distinto do cerne.

Utilidade: a madeira é largamente empregada em compensados, contraplacados, esculturas e obras de talha, modelos e molduras, esquadrias, móveis em geral, marcenaria, na construção civil, naval e aeronáutica, na confecção de pequenas caixas, lápis e instrumentos musicais, etc. A árvore é largamente empregada no paisagismo de parques e grandes jardins. Não deve faltar na composição de reflorestamentos heterogêneos de áreas degradadas de preservação permanente. Nunca deve ser plantada em agrupamentos homogêneos devido ao ataque de broca.

Informações ecológicas: planta decídua, heliófita ou esciófita, característica das florestas semidecíduas e menos freqüente na floresta ombrófita densa como a pluvial da costa atlântica. Ocorre preferencialmente em solos úmidos e profundos como os encontrados nos vales e planícies aluviais. Desenvolve-se no interior de florestas 
primárias, podendo também ser igualmente encontrada com espécie pioneira na vegetação secundária.

Fenologia: floresce durante os meses de agosto-setembro. Seus frutos amadurecem com a árvore totalmente desfolhada durante os meses de junho-agosto. Produz grande quantidade de sementes viáveis.

O desenvolvimento das plantas no campo é considerado rápido, podendo atingir 3-4 m de altura aos 2 anos (Lorenzi, 1992). A figura 7 mostra alguns exemplares juvenis da espécie em desenvolvimento no interior do fragmento em estudo.

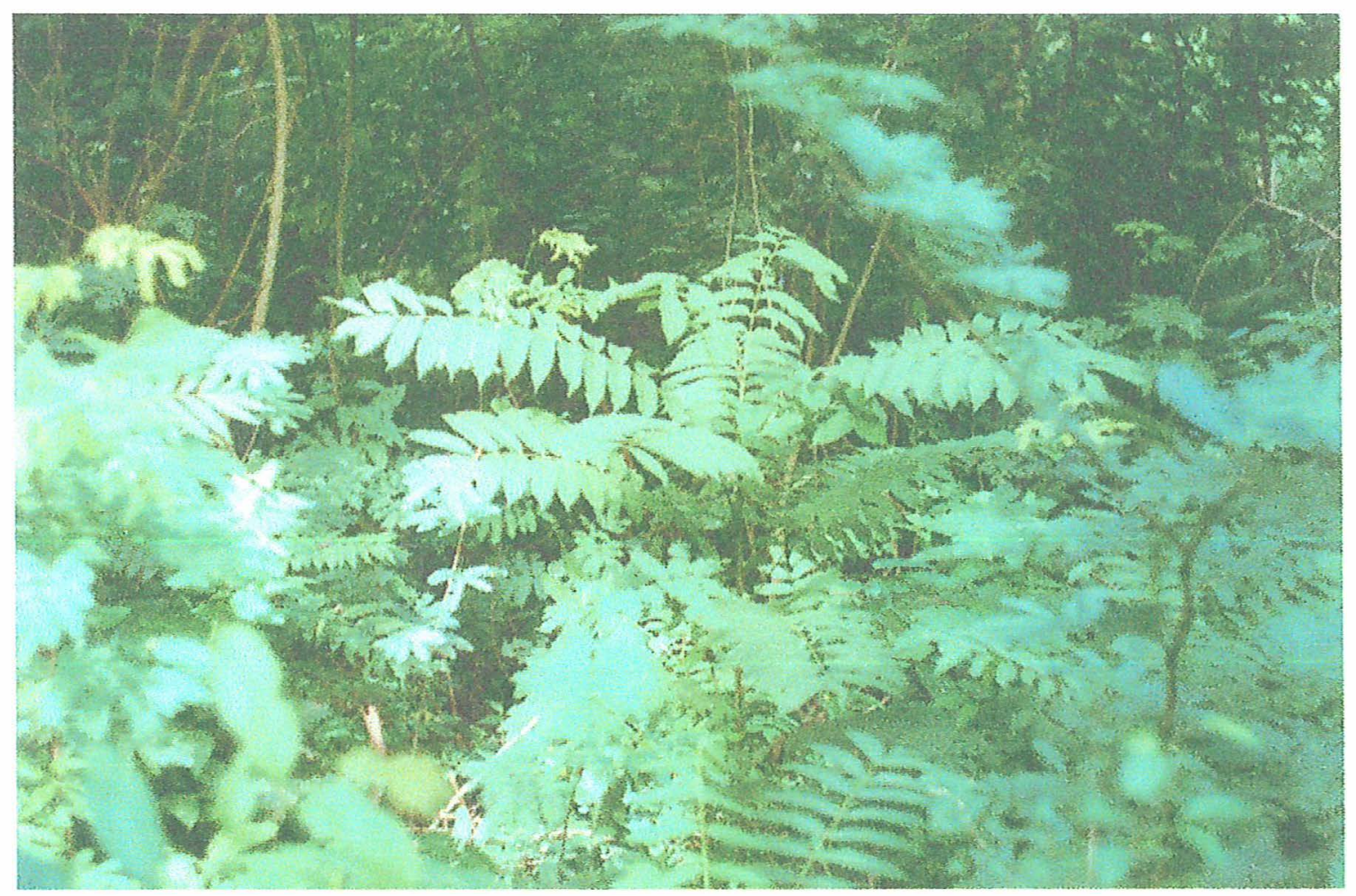

Fiqura 7 - Rluseraçãa de muda de cedro-rada. 


\subsubsection{Guatambú}

Aspidosperma parvifolium A. DC., pertencente à família botânica Apocynaceae, possui sinonímia botânica de Aspidosperma olivaceum M. Arg., Aspidosperma spp, Macaglia spp. Também possui sinonímia popular de guatambú-oliva, guatambú-branco, guatambú-legítimo, tambú, pequiá-marfim, pequiá- branco, dentre outros. A figura 8 exibe exemplar juvenil da espécie, cultivado sob dossel de fragmento florestal.

Características morfológicas: altura de 10-15 m, com tronco de 40-60 $\mathrm{cm}$ de diâmetro. Folhas glabras, membranáceas, de coloração prateada na pagina inferior, de 5-10 cm de comprimento por $1-3 \mathrm{~cm}$ largura (Lorenzi, 1992). Suas inflorescencias são subterminais ou terminais, glabras, medindo $3-4 \mathrm{~cm}$ e flores com cálice provido de lobos ovado-agudos, com $1 \mathrm{~mm}$; corola branca ou amarelo-clara, 5-6 $\mathrm{mm}$ de comprimento, pilosa internamente ou sem pêlos; ovário constantemente vestido de pêlos brancos; estigma quase clavado,(Rizzini, 1978).

Ocorrência: Sul da Bahia, até o Rio Grande do Sul, Minas Gerais, Goiás e Mato Grosso do Sul, principalmente nas florestas pluvial atlântica e semidecídua de altitude.

Madeira: moderadamente pesada (densidade de $0,87 \mathrm{~g} / \mathrm{cm}^{3}$ ), dura, resistente, grã direita, lisa ao tato, de grande durabilidade natural.

Utilidade: A madeira é muito utilizada na construção civil, como vigas, caibros, ripas, tacos para assoalhos, para confecção de peças torneadas, formas para calçados, cabos de ferramentas agrícolas, para obras expostas, como dormentes, mourões, cruzetas, etc. A árvore é bastante ornamental, podendo ser usada com sucesso no paisagismo em geral.

Informações ecológicas: planta semidecídua, heliófita, característica da floresta pluvial da encosta atlântica, ocorrendo em menor frequência, na floresta semidecídua de altitude. Ocorre tanto no interior da floresta primária densa, como em 
formações secundárias. produz anualmente grande quantidade de sementes viáveis amplamente disseminadas pelo vento.

Fenologia: floresce a partir do final do mês de agosto junto com o surgimento da nova folhagem, prolongando-se até o início de novembro. Os frutos amadurecem em julho-agosto.

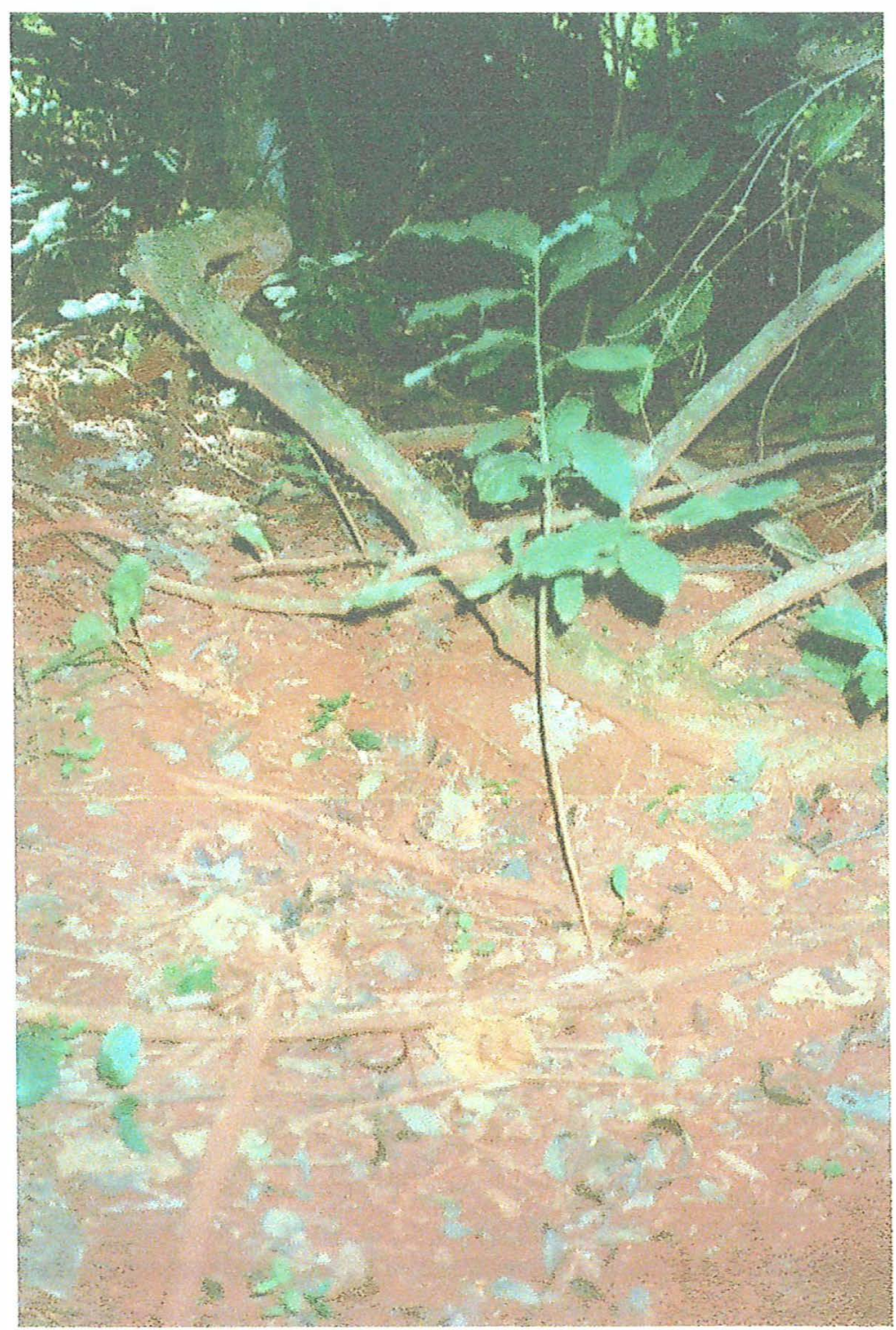

Figura 8 - Nustração de muda de quatambú. 
O desenvolvimento das plantas no campo é rápido, podendo atingir 3-4 m aos dois anos, segundo Lorenzi (1992).

\subsubsection{Ipê Roxo}

Tabebuia avellanedae Lor. ex Griseb., pertencente à família botânica Bignoniaceae, possui sinonímia botânica de Tecoma ipe Mart. ex L. Shum., Tecoma avellanedae (Lor. ex Griseb.) Speg., Handroanthus avellanedae(Lor. ex Griseb.) Mattos, Tabebuia ipe (Mart.) Standl., possuindo também sinonímia popular de paud'arco-roxo, ipê-roxo-da-mata, ipê-preto, ipê-comum, ipê-cavatã, lapacho, peúva, piúva.

Características morfológicas: altura de 20-35 m, com tronco de 60-80 $\mathrm{cm}$ de diâmetro. Folhas compostas 5-folioladas, folíolos quase glabros, de $5-13 \mathrm{~cm}$ de comprimento por 3-4 cm de largura, segundo Lorenzi(1992).

Ocorrência: Maranhão até o Rio Grande do Sul. É particularmente freqüente nos estados de Mato Grosso do Sul e São Paulo, até o Rio Grande do Sul, na floresta latifoliada semidecídua da bacia do Paraná.

Madeira: pesada (densidade $1,03 \mathrm{~g} / \mathrm{cm}^{3}$ ), dura, dificil de ser serrada, muito resistente, superficie pouco brilhante, rica em cristais verdes de lapachol, de grande durabilidade mesmo sob condições favoráveis ao apodrecimento.

Utilidade: a madeira é própria para obras externas e construções pesadas, tanto civil quanto navais, como vigas, postes, dormentes, pontes, tacos e tábuas para assoalho, tanoaria, tacos de bilhar, bengalas, eixos de roda, dentes de engrenagem, bolas para jogos, etc. A árvore em florescimento é um belo espetáculo da natureza. É a espécie de ipê roxo mais largamente utilizada no paisagismo em geral na região sul do país. É ótima para plantios mistos em áreas de preservação permanente. Também possui propriedades medicinais (cicatrizante).

Informações ecológicas: planta decídua, heliófita, característica da floresta latifoliada semidecídua da bacia do Paraná. Apresenta dispersão ampla, porém de ocorrência esparsa, tanto na mata primária densa como nas formações secundárias. 
Ocupa na mata primária o dossel superior. Produz anualmente grande quantidade de sementes, amplamente disseminadas pelo vento.

A figura 9 exibe um exemplar juvenil, plantado sob dossel do fragmento em estudo.

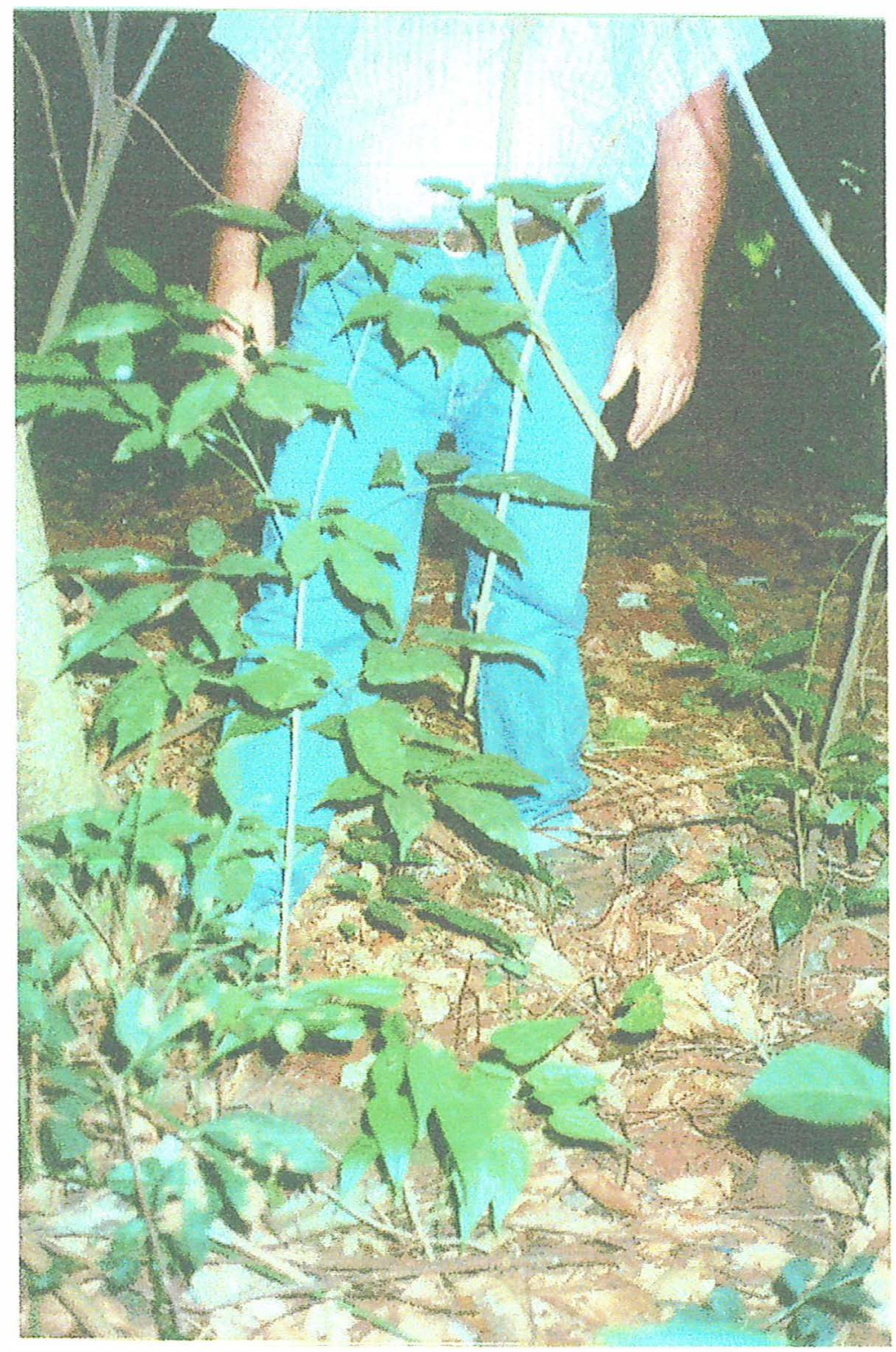

Figuna 9 - Tustração de muda de ipêt-roxa. 
Fenologia: floresce durante os meses de junho-agosto, com a planta quase totalmente despida da folhagem. Os frutos amadurecem em agosto-novembro (Lorenzi, 1992).

O desenvolvimento das plantas em campo é rápido, podendo atingir 3,5 $\mathrm{m}$ aos 2 anos

\subsubsection{Jatobá}

Hymenaea courbarl L. var. stithocarpa (Hayne) Lee et Lang., pertencente à familia botânica Leguminosae-Caesalpinoideae. Possui sinonímia botânica de Hymenaea stilbocarpa Hayne, ainda possuindo sinonímia popular de jataí, farinheira, jataíba, burandã, imbiúva, dentre outros.

Características morfológicas: altura de 15-20 m, com tronco de até 100 $\mathrm{cm}$ de diâmetro. Folhas compostas de dois folíolos brilhantes, de $6-14 \mathrm{~cm}$ de comprimento(Lorenzi, 1992). Os folíolos, segundo Rizzini (1978) são oblongolanceolados, oblíquos, com o ápice mais atenuado do que nas outras espécies e acuminado, a base bem auriculada em um dos lados, coriáceos, glabros, quase sem retículo ou delicadamente reticulados, com glândulas translúcidas. Flores em corimbos terminais pauciflores; cálice fulvo-tomentoso, com lacínias de $12-15 \mathrm{~mm}$ de comprimento. Fruto indeiscente, mais ou menos cilíndrico, duro, pardo-escuro ou quase negro, opaco ou algo brilhante, medindo $8-15 \times 3-5 \mathrm{~cm}$, com endocarpo carnoso, farináceo, comestível, amarelo-claro e adocicado, contendo 3-6 sementes sem endosperma.

Ocorrência: Piauí até o norte do Paraná na floresta semidecídua, tanto em solos de alta quanto de média fertilidade (cerradões).

Madeira: Pesada (densidade de $0,96 \mathrm{~g} / \mathrm{cm}^{3}$ ), muito dura ao corte, de média resistência ao ataque de insetos xilófagos sob condições naturais, alburno brancoamarelado, espesso e nitidamente diferenciado do cerne. 
O desenvolvimento das plantas no campo é médio, onde vemos, através da figura 10, exemplar juvenil no interior do fragmento em estudo.

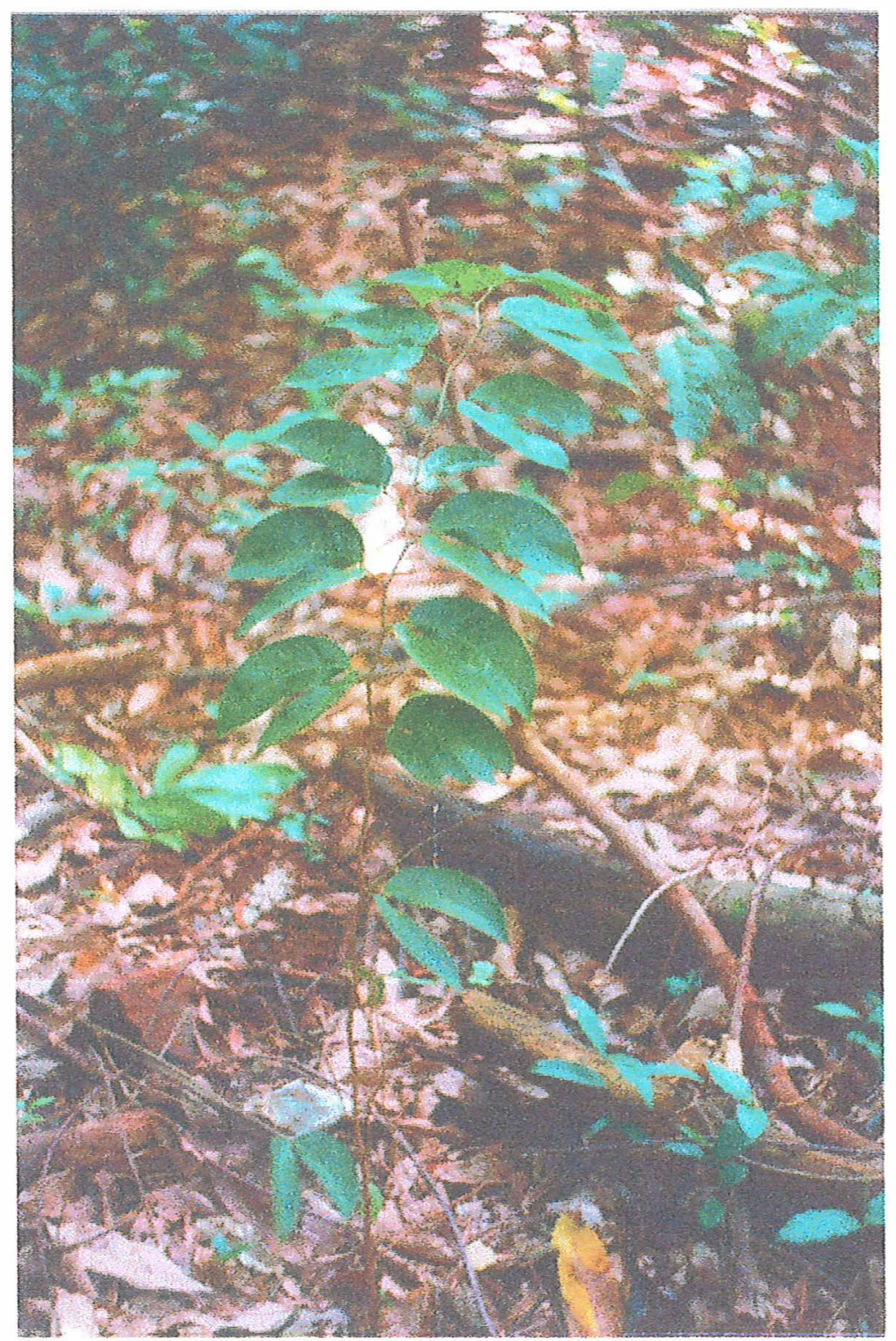

Figuna 10 - Mustraçãa de muda de Jatoliá.

Utilidades: a madeira é empregada na construção civil, como vigas, caibros, ripas, para acabamentos internos, como marcos de portas, tacos e tábuas para assoalhos, para confecção de artigos de esportes, cabos de ferramentas, peças torneadas, 
esquadrias e móveis. A árvore, de fácil multiplicação, não pode faltar na composição de reflorestamentos heterogêneos e, na arborização de parques e grandes jardins. Os frutos contém uma farinha comestível e muito nutritiva, consumida tanto pelo homem quanto pelos animais silvestres.

Informações ecológicas: planta semidecídua, heliófita ou esciófita, seletiva xerófita, característica da floresta latifoliada semidecídua. É uma planta pouco exigente em fertilidade e umidade do solo, geralmente ocorrendo em terrenos bem drenados. Produz anualmente grande quantidade de sementes viáveis.

Fenologia: floresce durante os meses de outubro-dezembro. os frutos amadurecem a partir do mês de julho(Lorenzi, 1992).

\subsection{Formação das Mudas}

As mudas foram formadas no viveiro encontrado na respectiva Usina Hidrelétrica, a partir de sementes cultivadas em sacos plásticos de polietileno com 2 litros de capacidade. Utilizou-se substrato composto por $50 \%$ de terra de subsolo arenoargilosa calada com $500 \mathrm{~g}$ de calcário dolomítico por $\mathrm{m}^{3}$ e $50 \%$ de esterco de curral curtido, que recebeu adubação de base constituída de $150 \mathrm{~g}$ de $\mathrm{N}, 700 \mathrm{~g}$ de $\mathrm{P}_{2} \mathrm{O}_{5}, 100 \mathrm{~g}$ de $\mathrm{k}_{2} \mathrm{O}$ e $200 \mathrm{~g}$ de "fritas" (FTE Br 9) para cada $\mathrm{m}^{3}$ de substrato, mais $100 \mathrm{~g}$ de N e 100 $\mathrm{g}$ de $\mathrm{k}_{2} \mathrm{O}$ parceladas em 3 aplicações para cada 500 saquinhos de dois litros. Foram levadas a campo após 6 meses de enviveiramento, sendo que cada espécie apresentava tamanhos diferenciados. Mesmo dentro de cada lote de mudas, existia diferenças de tamanho em altura, provavelmente pela heterogeneidade do genótipo de cada espécie. Todos os lotes foram produzidos sob sombrite com $50 \%$ de sombra. 


\subsection{Plantio em Campo}

Em campo, foram abertas covas com $30 \times 30 \times 30 \mathrm{~cm}$, iniciadas em dezembro de 1994, onde foram plantadas as mudas em março de 1995. Foram coletadas três amostras compostas de solo oriundas cada uma delas de 15 amostras simples colhidas respectivamente em cada uma das áreas e realizada análise de fertilidade de macro e micro nutrientes no Instituto Campineiro de Análise de Solo e Adubo Ltda S/A em 29/12/94. Os teores de macro e micronutrientes nas três áreas foram semelhantes e altos, excetuando-se o fósforo e potássio na área 1, que estavam com nível médio, onde todas as covas foram adubadas com $200 \mathrm{~g}$ de superfostato triplo e $100 \mathrm{~g}$ de Cloreto de Potássio. Também não foi aplicado calcário em nenhuma das áreas, pois a saturação de bases estava próxima a 80 \% nas três áreas, com teores de $\mathrm{Ca}$ e $\mathrm{Mg}$ altos.

\subsection{Parâmetros Estudados}

\subsubsection{Luz : Intensidade de luz e Índice de Luminosidade Relativa}

Este parâmetro também foi calculado através de dados de medições da luminosidade utilizando-se um luxímetro digital por ocasião da coleta dos dados de crescimento, no período de 10:00 hs às 13:00 hs, tomados rapidamente em 15 pontos de cada área experimental e em um ponto em aberto, na parte externa do fragmento, ao lado da respectiva área. Para cálculo do índice, comparou-se porcentualmente a luminosidade média encontrada sob o dossel em cada área experimental com a luminosidade externa total, conforme equação :

$$
\mathrm{ILR}=\underline{\text { luminosidade dentro do fragmento }} \times 100
$$

luminosidade a céu aberto 


\subsubsection{Temperaturas do Solo}

As medições de temperatura do solo a $10 \mathrm{~cm}$ de profundidade foram também realizadas simultaneamente as demais, através de termômetro digital com haste de aço inoxidável.

\subsubsection{Umidade do solo}

As porcentagens de umidade encontrada no solo sob o fragmento na capacidade de campo (0,33 atm) e no ponto de murchamento ( $15 \mathrm{~atm})$, foram obtidas através de coleta de 3 amostras de solo colhidas em anéis de PVC de volume conhecido, analizadas pelo Laboratório de Análise de Solo do Departamento de Ciência do Solo da ESALQ/USP. A umidade atual do solo foi medida simultaneamente às leituras de crescimento, tomando-se 15 amostras simples em cada uma das três áreas, transformadas em uma amostra composta por área, que foram acondicionadas em sacos plásticos fechados hermeticamente. A análise da umidade foi realizada no laboratório de óleos isolantes da CPFL, tomando-se $10 \mathrm{~g}$ de solo de cada amostra, levados à estufa a $110^{\circ} \mathrm{C}$ até peso constante, segundo método da EMBRAPA (1979).

\subsubsection{Crescimento em altura}

O crescimento em altura foi acompanhado por medições prédeterminadas, através de trena de aço, medindo a muda inteira do colo à ultima gema apical do ramo principal. As medições foram feitas em todas as datas por um mesmo indivíduo, sendo anotadas em planilha de campo por um segundo indivíduo, também o mesmo para todas as leituras, a fim de se evitar erros por maneiras diferentes de medição. A primeira leitura foi realizada em abril de 1995, logo após o término do plantio, a segunda em junho de 1995, a terceira em novembro de 1995, a quarta em fevereiro de 1996 e a última em maio de 1996. 
Os dados foram digitados no programa EXCEL FOR WINDOWS (planilha eletrônica), onde os cálculos como somas, médias, desvio padrão e intervalo de confiança foram processados.

A comparação das médias de altura da última leitura e da primeira em cada espécie foi realizada através do teste t Student, pelo SAS. Os gráficos das médias de crescimento foram gerados pelo EXCEL, bem como o intervalo de confiança a $5 \%$ para a média. A comparação de médias interespecíficas de incremento foi realizada através do teste não paramétrico Wilcoxon, pelo fato dos dados apresentarem heterogeneidade de variâncias e não apresentarem distribuição normal, provavelmente pela grande variabilidade genética do material trabalhad o e pelas dificuldades de se realizar um bom controle local.

\subsubsection{Crescimento em diâmetro do colo}

Este parâmetro foi acompanhado por medições trimestrais, através de paquímetro com precisão de $0,01 \mathrm{~mm}$, na altura do colo da planta, simultaneamente, e da mesma forma que as medições de crescimento em altura.

A comparação das médias de diâmetro de colo da última leitura e da primeira em cada espécie foi realizada atravéz do teste t Student, pelo SAS. Os gráficos das médias foram gerados pelo EXCEL, bem como o intervalo de confiança a $5 \%$. A comparação de médias de incremento interespecífico foi realizada através do teste não paramétrico Wilcoxon, pelo fato dos dados apresentarem heterogeneidade de variâncias e não apresentarem distribuição normal.

\subsubsection{Mortalidade}

Foi definida pela porcentagem remanescente da quantidade de mudas na última leitura comparada com a quantidade inicial, através da planilha eletrônica EXCEL. 


\section{RESULTADOS E DISCUSSÃO}

\subsection{Luz}

A intensidade luminosa registrada a céu aberto, no período de abril de 1995 a maio de 1996, mostrou valor médio de 95,80 klux, oscilando de 73 klux registrados em novembro de 1995 a um máximo de 136 klux em fevereiro de 1996, medidos entre 10:00 e 14:00 hs, conforme figura 11. O pico coincide com o período de maior radiação solar global média ( Pedro Júnior et alii, 1989).

\section{LUMINOSIDADE A CEU ABERTO}

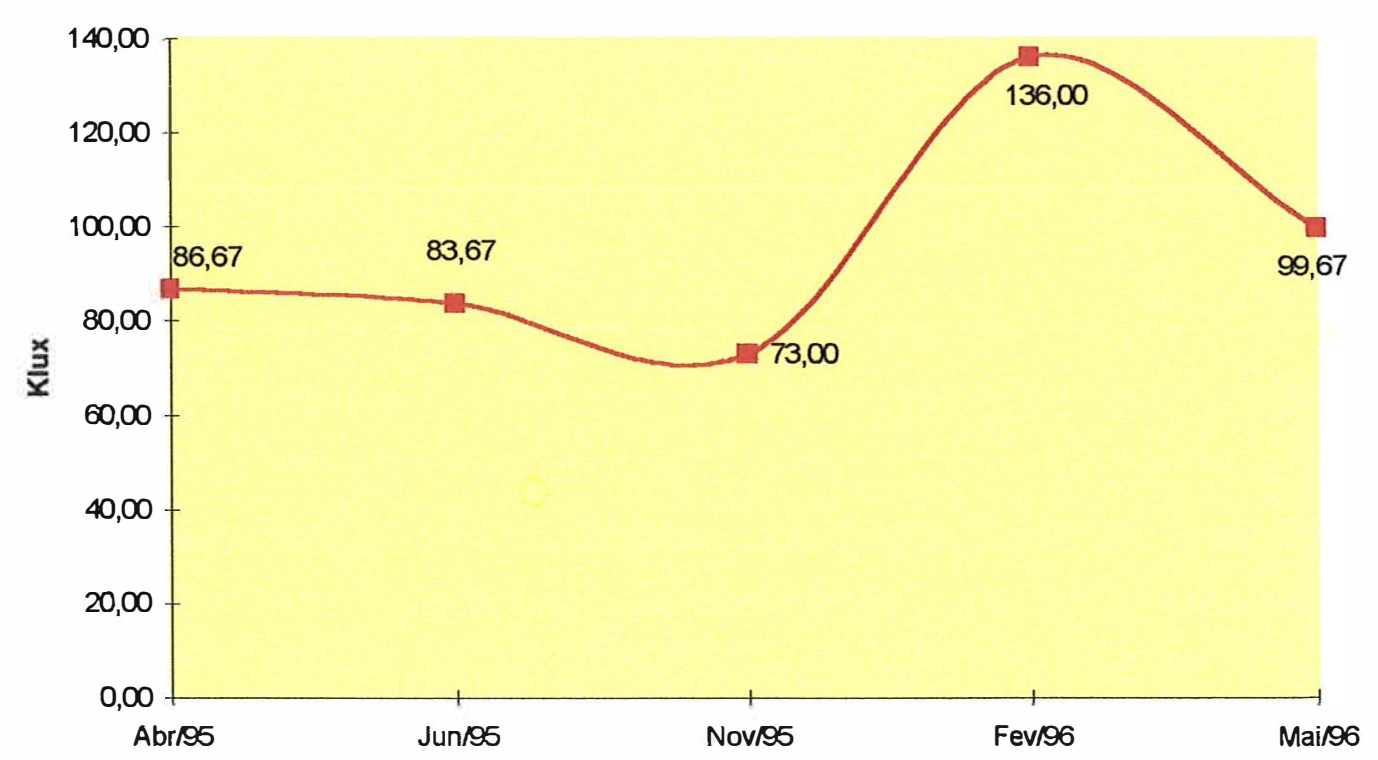

Figurall. Gráfica de intensidade luminosa incededa na área cxporimental fora do fragmento florestal (aborto), en klux. 
Observa-se que a quantidade de luz no mês de novembro apresenta-se abaixo das outras medidas, o que pode indicar maior ocorrência de nebulosidade em novembro, no momento das medições.

A intensidade luminosa sob o dossel do fragmento exibiu valores médios apresentados na figura 12, oscilando de 0,83 a 2,0 Klux.

São observados dois picos de luminosidade, um em junho outro em fevereiro. Apesar do nível de luminosidade a céu aberto no mês de junho ser um dos mais baixos do ano, no sub-bosque a luz chega com maior intensidade, devido ao desfolhamento maior das espécies formadoras do dossel. Este comportamento é característico deste tipo de floresta semidecídua. O pico de luminosidade sob o dossel no mês de fevereiro é coincidente com a época de maior radiação solar global na região, segundo Pedro Júnior et alii (1989).

\section{LUMINOSIDADE SOB DOSSEL}

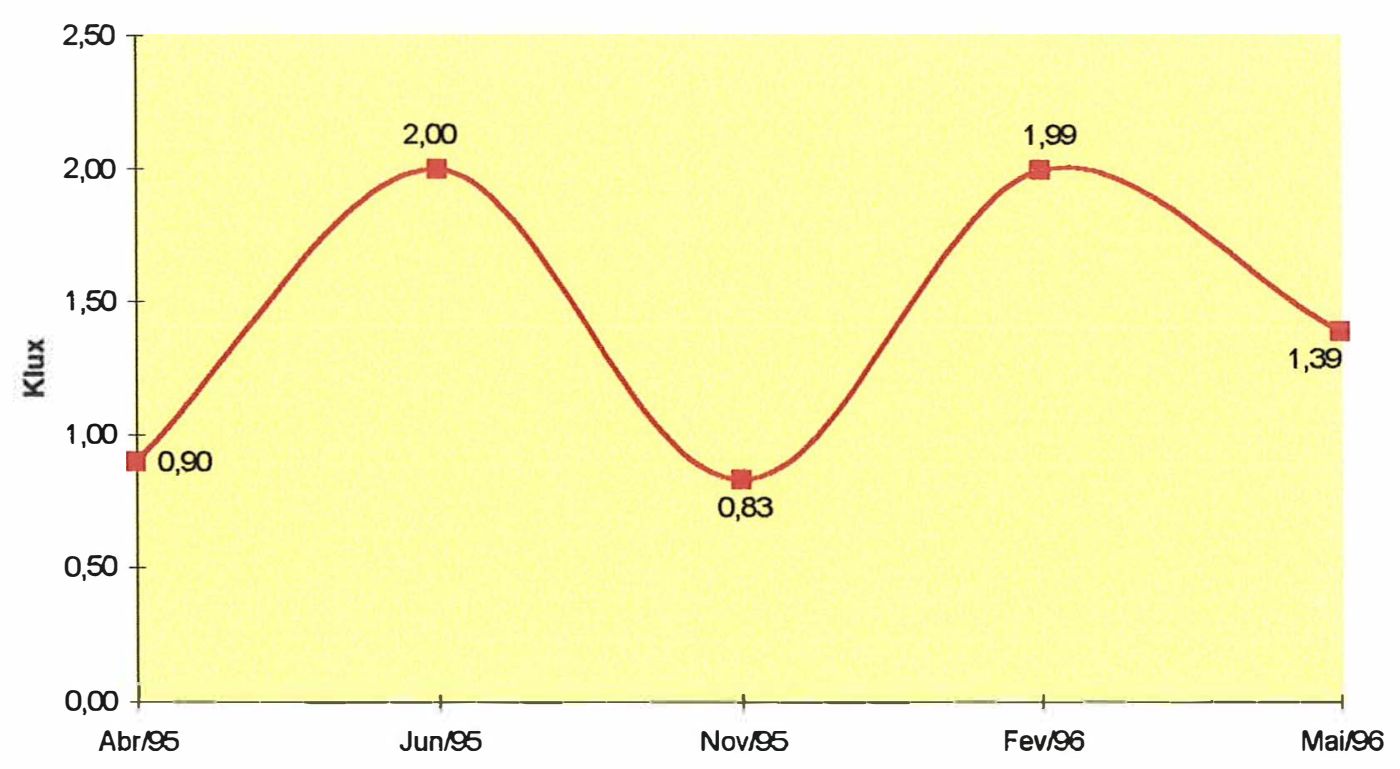

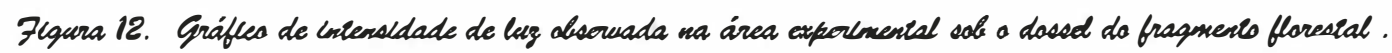

O Índice de Luminosidade Relativa - ILR sob o dossel do fragmento, ou seja, a intensidade de luz encontrada sob o fragmento em relação à intensidade de luz a céu aberto, apresentou os valores exibidos na figura 13. 
Nota-se a ocorrência de um pico na curva do IRL no mês de junho, devido à menor quantidade de folhas no dossel, que permite maior penetração de luz.

Em estudos desenvolvidos na Serra do Japí, localizada no interior do Estado de São Paulo em floresta mesófila, Morellato (1992) observou que o pico de queda de folhas ocorreu no final da estação seca (ago/set), decaindo em outubro e novembro, também observado por Poggiani \& Monteiro Júnior (1990), Cesar (1988) e Pagano (1985) em estudos desenvolvidos em outras florestas semidecíduas do interior de São Paulo. Provavelmente se as medições tivessem sido tomadas mensalmente, encontraríamos um maior pico em setembro.

\section{ÍNDICE DE LUMINOSIDADE RELATIVA - ILR}

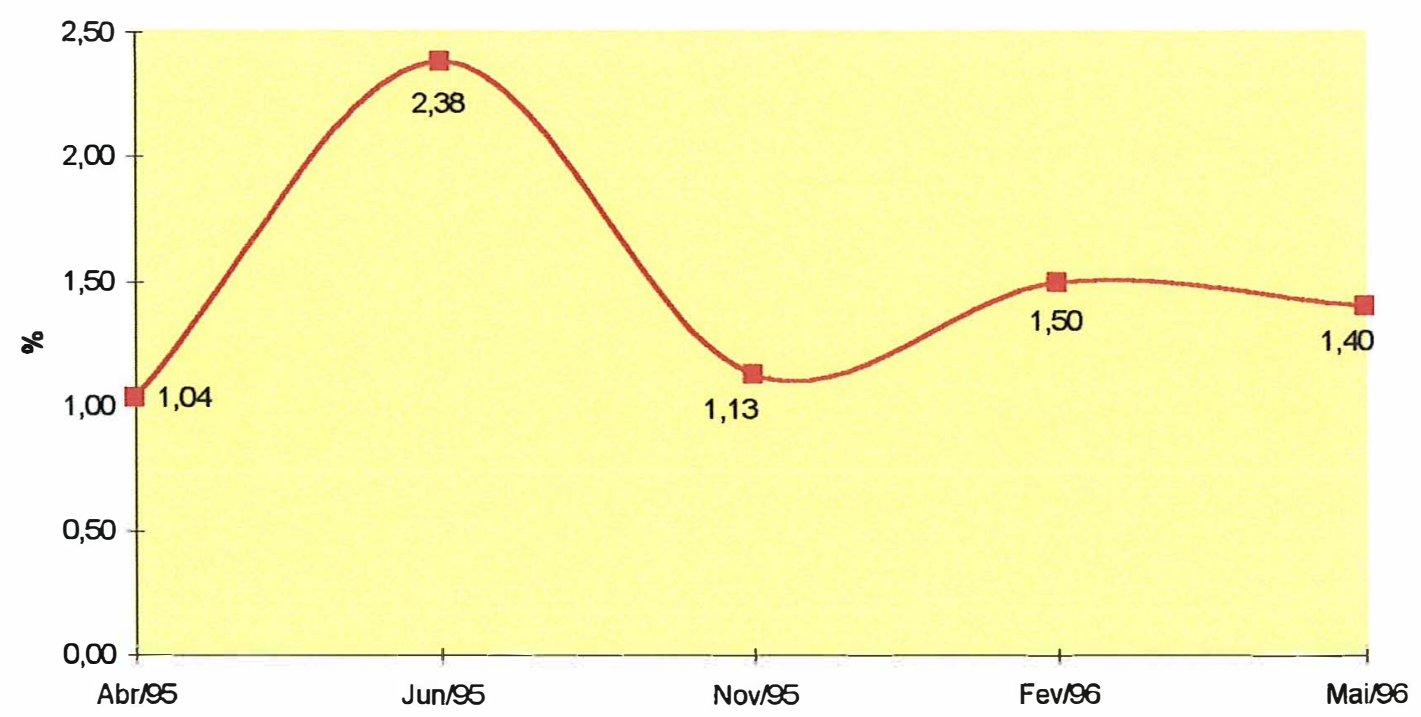

Figura 13. Gráfica mastranda a indice de Lumirasidade Relativa - ILR. Intensidade de luz média em

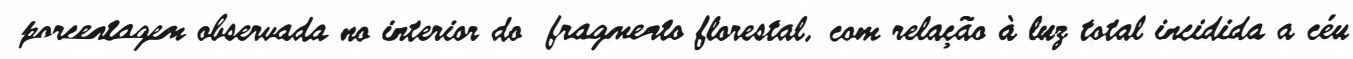
aberts.

Por tratar-se de fragmento de floresta semidecídua em regeneração (capoeira) com baixa extratificação e grande irregularidade no dossel, era de se esperar um IRL mais elevado no mês de julho, segundo estudos de Engel \& Poggiani (1990), disponibilizando assim mais luz às plântulas e estágios juvenis de espécies encontradas no 
sub-bosque do fragmento, principalmente nas horas de sol mais alto. Os valores de IRL encontrados são similares aos mencionados por Spurr (1980) para o sub-bosque de florestas tropicais, devido à grande ocorrência de lianas em todo o fragmento, com distribuição desuniforme e ao grande número de espécies emergentes, parte do processo de sucessão vegetal encontrado no atual estágio de desenvolvimento do fragmento.

Presenciou-se a existência de raios de sol, que penetravam por brechas do dossel sob forma de luz direta, formando um mosaico de luz no piso florestal, também observado por Evans (1973) e Whatley \& Whatley (1982). Portanto, a intensidade de luz medida e apresentada não representa a luminosidade total que penetrou no interior do fragmento no período.

A teoria que coloca a condição indispensável de ocorrência de clareiras em florestas tropicais primárias, permitindo uma maior oferta de luz aos estágios iniciais de espécies arbóreas encontradas no interior das mesmas, parece se confirmar também para os estágios iniciais de desenvolvimento de espécies arbóreas encontrados sob dossel de fragmentos de florestas semidecíduas em regeneração.

Engel \& Poggiani (1990), estudando a influência do sombreamento no desenvolvimento e sobrevivência de essências florestais nativas, trabalharam com níveis de sombreamento de $0,42,68$ e $82 \%$ em viveiro e comparou em sua discussão dos resultados estes niveis aos encontrados em florestas naturais. Observaram que as diferentes espécies tinham um comportamento característico em relação à intensidade de luz. 


\section{2 - Temperatura do solo}

A curva de temperatura do solo acompanha a curva de temperatura ambiente, mantendo-se ligeiramente abaixo em todas épocas do período, como pode ser visto através da figura 14 .

Em trabalho de pesquisa desenvolvido na Floresta Nacional do Jamarí RO, França \& Poggiani (1994) observaram que no interior de todas as áreas estudadas a temperatura do ar, nas horas mais quentes do dia gira ao redor de $30^{0} \mathrm{C}$, ou seja, $7{ }^{0} \mathrm{C}$ abaixo da temperatura do ambiente exterior e a temperatura da camada superficial do solo acompanha de perto a temperatura do ar.

As temperaturas máxima e mínima das camadas superficiais do solo acompanham as máximas e mínimas do ar, mas na medida em que aprofundam-se os pontos de medida no solo, as temperaturas máximas e mínimas tendem a se igualar à temperatura média anual do ar.

\section{Temperaturas do ar e solo}

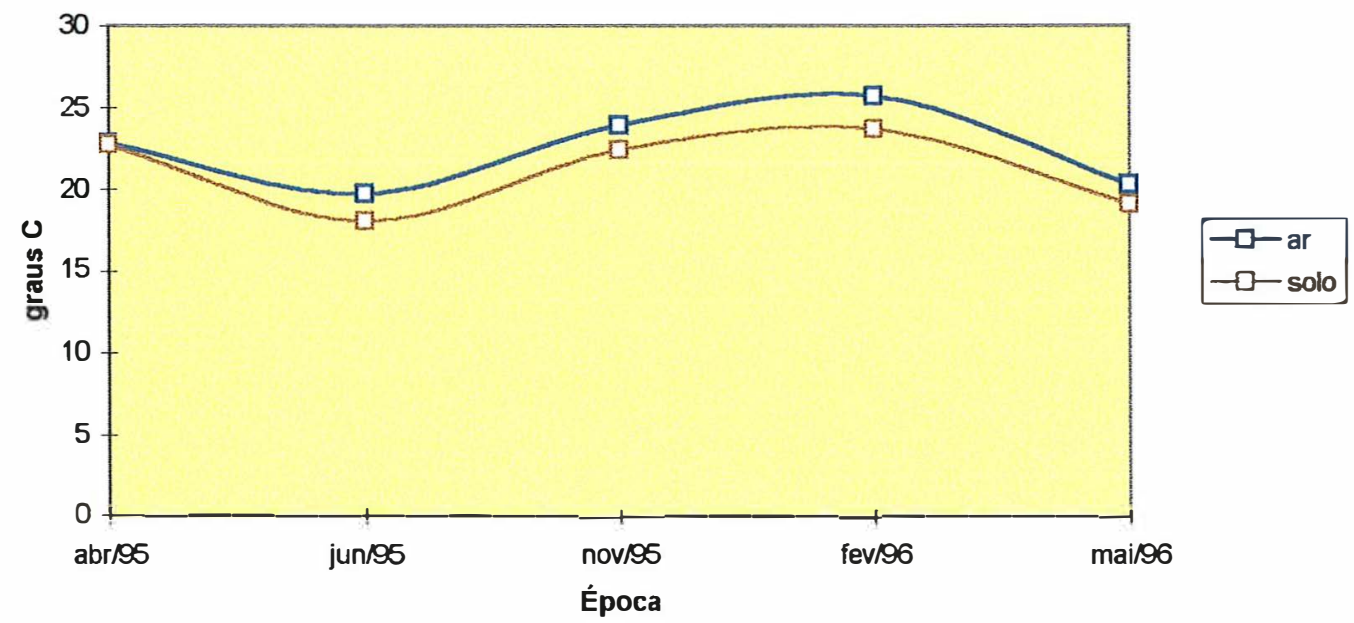

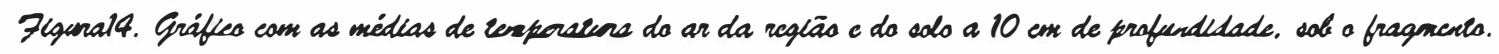

Considerando que o sistema radicular das mudas encontra-se ainda pouco desenvolvido e superficial, as oscilações de temperatura ambiente irão influenciar o 
desenvolvimento das mesmas, acelerando ou reduzindo os processos metabólicos envolvidos, juntamente com a disponibilidade de água no solo.

\section{3 - Umidade do solo}

A umidade do solo também apresenta sazonalidade, implicando grandes variações na quantidade e disponibilidade de água no solo ao longo do ano, conforme mostra a figura 15. Esta sazonalidade é função principalmente da distribuição das chuvas na região ao longo do período.

Observou-se uma menor umidade no mês de junho, ocasião em que ocorrem as menores precipitações do ano, o que pode ser notado pelo balanço hídrico exibido na figura 2 , quando a umidade do solo encontra-se abaixo do ponto de murchamento. A umidade média do solo no ponto de murchamento $(15,0$ atm) foi de $15,30 \%$ e na capacidade de campo $(0,33 \mathrm{~atm})$, foi de $23,66 \%$.

\section{Umidade de solo}

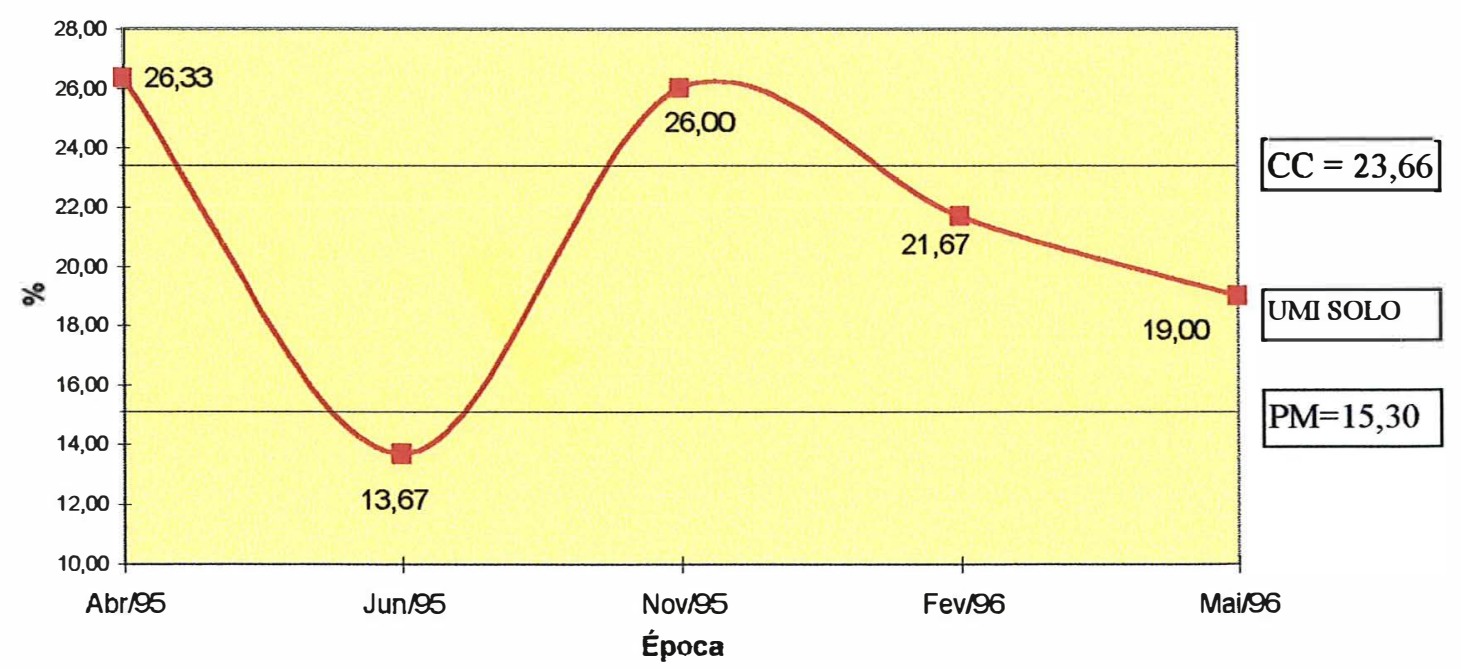

7igura15. 2uautidade de áqua em porcentagem (cumidade atual) encontrada no solo sob a fragmento florestal. 
Segundo dados fornecidos pela Seção de Climatologia do * IAC, a precipitação pluviométrica na região do experimento reduziu-se de $104,5 \mathrm{~mm}$ em abril para $79 \mathrm{~mm}$ em maio e 19,3 mm em junho, chegando a tão somente $0,9 \mathrm{~mm}$ em agosto.

Sob o fragmento florestal em regeneração formando-se um folhedo que auxilia na retenção de água, todavia existe uma demanda acentuada de água pelas árvores em processo de franco crescimento. Segundo Spurr(1980), sob um bosque em crescimento, a competição das raízes das árvores reduz substancialmente a quantidade de umidade do solo disponivel para as plânturas do sub-bosque. Na região do experimento ocorre uma situação de déficit hídrico prolongado (figura 2), e a disponibilidade de água no solo às plantas, principalmente as com sistemas radiculares pequenos deve ser muito restrita, muitas vezes levando-as à condição de ponto de murchamento definitivo e à morte, antes do período chuvoso seguinte, o que empiricamente foi observado no subbosque do fragmento, onde várias plântulas e estágios juvenis de espécies nativas de ocorrência natural estavam nestas condições ou mesmo mortos. Os dados de umidade do solo abaixo do ponto de murchamento no mês de jun/95 corroboram estas observações.

Este fator ambiental limitado no período de seca é portanto extremamente importante para o crescimento, desenvolvimento e sobrevivência de estágios iniciais de espécies arbóreas nativas sob dossel de fragmento em regeneração.

Coincidentemente, nesta época do ano ocorre um grande desfolhamento na maioria das espécies arbóreas das florestas semidecíduas do interior do Estado de São Paulo, apontando para uma possível estratégia de economia de água por estas espécies.

Estudos desenvolvidos por Barbosa (1980), sobre aspectos de germinação e crescimento de Anadenanthera macrocarpa (Benth) Brenan, assinalaram que pouca atenção tem sido dada às plantas que crescem sob freqüentes e, muitas vezes, severos estresses hídricos. Ainda afirma ser a espécie homeoídrica, ou seja, consegue através de suas adaptações morfofisiológicas impedir o dessecamento do seu protoplasma, mantendo o potencial hídrico superior ao do meio mesmo em gradiente

\footnotetext{
* Dados não publicados, fornecidos pela Seção de Climatologia do IAC, Campinas, SP.
} 
considerável, com conseqüente restrição dos processos metabólicos de fotossíntese e respiração.

\section{4 - Considerações sobre os fatores ambientais e suas influências.}

No período de abril a junho de 1995, os fatores que se apresentaram limitantes ao desenvolvimento das mudas foram a umidade do solo abaixo do ponto de murchamento e a temperatura do solo. Neste período, o índice de luminosidade relativa mostrou-se mais favorável que nos demais períodos, mas mesmo assim, se manteve a níveis semelhantes ao encontrado em florestas primárias, restringindo o desenvolvimento das mudas.

No período de junho a novembro, observamos um aumento da temperatura, aumento da precipitação pluviométrica e umidade do solo e redução da luminosidade. Neste período, ocorreram as maiores taxas de incremento das mudas, o que aponta para uma influência positiva de todos os três fatores. A redução da luminosidade provavelmente não foi retilínea a partir de junho, pois as medidas foram trimestrais. O pico do desfolhamento em florestas de planalto no interior do Estado de São Paulo, ocorre no mês de setembro, o que provavelmente também ocorreu na área experimental, aumento da luminosidade até setembro e a partir daí a redução medida em novembro.

No período de novembro a fevereiro, observou-se que a luz foi um fator muito restrito pelo maior enfolhamento do dossel, o que restringiu muito o desenvolvimento das mudas, a despeito da umidade do solo e temperatura estarem elevados.

De fevereiro a maio de 1996, a luminosidade relativa se mantém muito baixa, a temperatura e umidade do solo decaíram, apresentando um período desfavorável ao crescimento das mudas. 


\subsection{Crescimento}

\subsection{1 - Crescimento em altura}

Todas as espécies apresentaram incremento em altura ao final do período, a despeito das restrições de alguns fatores ambientais, tais como intensidade luminosa e disponibilidade de água no solo em algumas épocas do período, como pode ser visto através da Tabela 3.

Tabela 3. Comparsesss de médias de altuna incicial e final em esalimeons entre a mudas plactadas no interior do fragueals.

\begin{tabular}{|c|c|c|c|c|}
\hline \multicolumn{5}{|c|}{ COMPARAÇÃO DE MÉDIAS DE ALTURAS INICIAL E FINAL } \\
\hline & & médias & & CV \\
\hline \multirow[t]{2}{*}{ ANGICO } & inicial & 73,46 & a & 17,35 \\
\hline & final & 99,29 & b & \\
\hline \multirow[t]{2}{*}{ CEDRO } & inicial & 24,70 & a & 46,56 \\
\hline & final & 50,31 & $\mathrm{~b}$ & \\
\hline \multirow[t]{2}{*}{ GUATAMBÚ } & inicial & 21,30 & a & 39,55 \\
\hline & final & 35,53 & $\mathrm{~b}$ & \\
\hline \multirow[t]{2}{*}{ IPÊ-ROXO } & inicial & 11,63 & a & 43,48 \\
\hline & final & 25,14 & b & \\
\hline \multirow[t]{2}{*}{ JATOBÁ } & inicial & 63,36 & $a$ & 19,34 \\
\hline & final & 83,66 & b & \\
\hline
\end{tabular}

As médias por espécie acompanhadas da mesma letra não diferem entre sí pelo teste t a $1 \%$.

\subsubsection{1 - Altura média do angico}

$\mathrm{O}$ angico exibiu seu maior crescimento médio no período de junho a novembro, o que pode ser visto na figura 16. Neste intervalo de tempo, ocorreu uma elevação da temperatura ambiente e do solo, fatores que somados, indicam uma influência no maior crescimento neste período.

A quantidade de luminosidade que atingiu o interior do fragmento foi alta em junho, reduzindo-se a partir dai até novembro de 1995. Conforme observado por Morellato (1992), Cesar (1988), Pagano(1985) e Poggiani \& Monteiro Júnior (1990), o 
pico de desfolhamento em florestas semidecíduas no interior de São Paulo ocorre entre os meses de agosto e setembro no final da estação seca, reduzindo-se em outubro a novembro, o que provavelmente também ocorreu no fragmento em estudo, porém não observado pico em setembro pela freqüência de medições deste parâmetro ter sido trimestral. Assim sendo, este fator também contribuiu decisivamente para o maior desenvolvimento da espécie neste período. Por ser uma espécie heliófita, segundo Lorenzi (1992), se enquadrando no grupo das secundárias iniciais segundo definição de Martinez-Ramos (1985), exige grande disponibilidade de luz para seu desenvolvimento.

\section{ALTURA MÉDIA DO ANGICO}

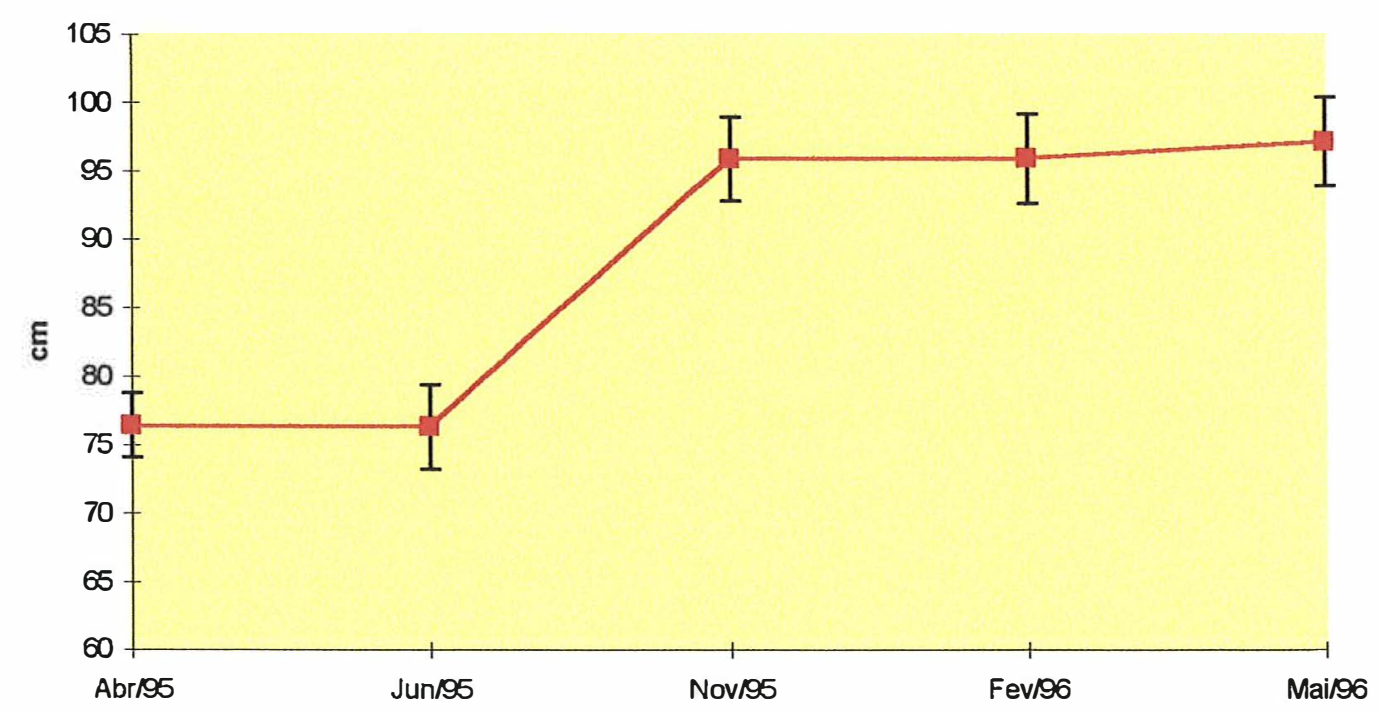

7igura 16. Altura média en centimetros de mudas de amgica, negistrada na perioda de junl95 a mail 96. cultivados na interion de fragmenta flarestal. As barras fretas verticais expressam a intervala de carficares a $5 \%$.

A umidade do solo foi muito limitada no período de maio a setembro, aumentando a partir deste último mês, conforme balanço hídrico do período.

Pelo fato desta espécie ser xerófita, segundo Lorenzi (1992), bastante resistente ao déficit hídrico, esta característica pode ter colaborado para seu crescimento mesmo considerando a limitação de água disponível no solo no período. 
Estudando aspectos da germinação e crescimento desta espécie, Barbosa (1980) constatou que a fase de plântula apresenta grande tolerância à desidratação, quando submetidas ao processo de dessecamento em câmaras de umidade relativa diversa em condições de laboratório. Também a mesma autora observou que as plantas jovens desta espécie são resistentes ao dessecamento em condições de campo, mas deve-se acrescentar que, no período subsequente de alongamento dos órgãos, as plantas jovens necessitam de bom suprimento hídrico para dar continuidade ao seu crescimento.

No período seguinte, de nov/95 a fev/96, o crescimento continua, mas apresentando redução do seu incremento. Embora a temperatura tenha aumentado, o balanço hídrico tenha mostrado um excedente no período e, consequentemente, a umidade do solo tenha se mantido em um patamar elevado, a luminosidade relativa reduziu-se pelo maior enfolhamento do dossel, consequentemente reduzindo-se seu crescimento.

Portanto, a espécie respondeu em maior incremento de altura no período em que se somaram os fatores microclimáticos favoráveis às suas exigências.

\subsubsection{2 - Altura média do cedro}

O cedro teve um comportamento muito parecido com o angico no período de junho a novembro, onde o somatório dos fatores microcrimáticos foi favorável ao seu desenvolvimento, conforme exibido na figura 17.

No período de novembro a fevereiro, porém a espécie continuou crescendo, a despeito de uma menor luminosidade relativa, por ser mais tolerante à sombra que o angico, tendo características heliófitas e esciófitas segundo Lorenzi (1992), demonstrando se enquadrar em estágio sucessional um pouco mais avançado que a outra , sendo uma espécie secundária intermediária.

A partir de fevereiro de 1996, a espécie apresentou crescimento negativo, devido ao ataque de broca do cedro, Hypsipyla grandella (Zeller, 1848) (Lepidoptera, pyralidae) em diversas mudas. 


\section{ALTURA MÉDIA DO CEDRO}

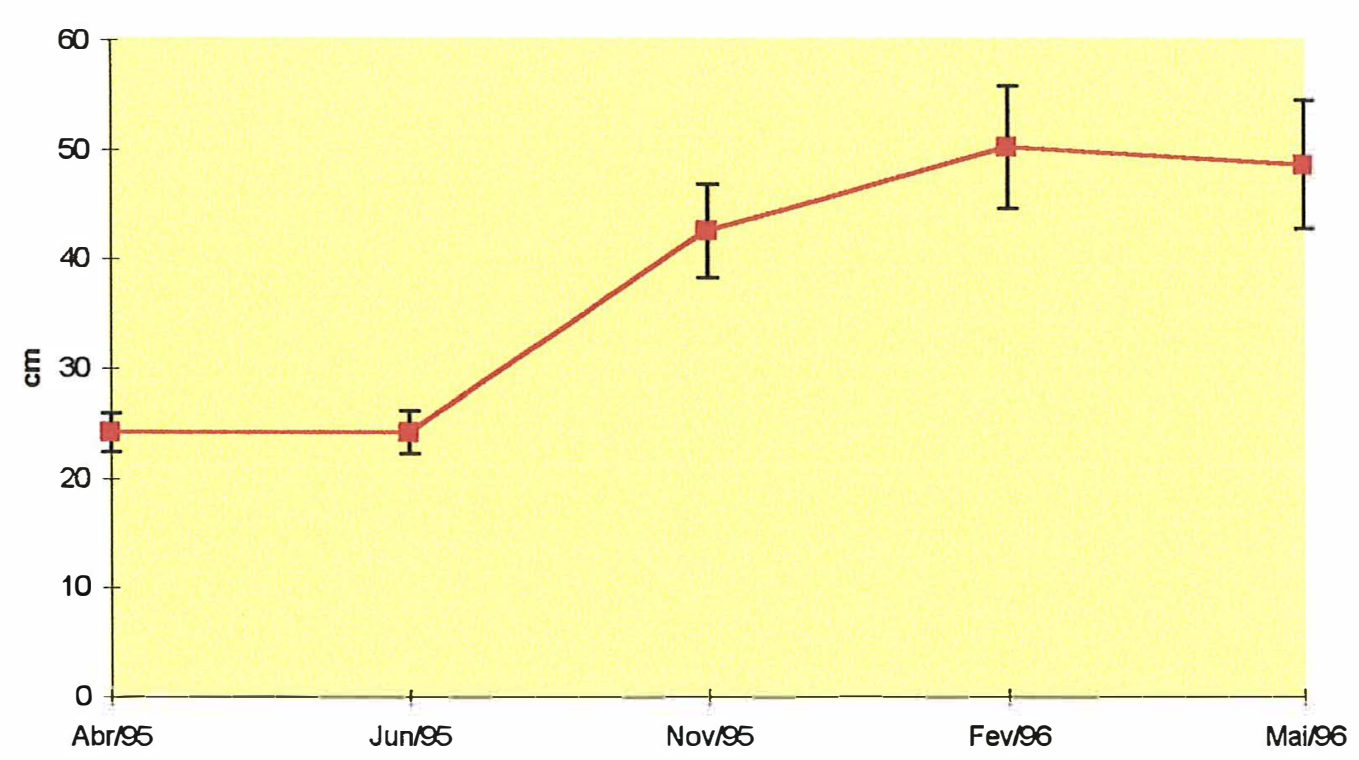

Fiqura 17. Altura média em centímetros das mudas de cedra, na perioda de jun/95 a mail96, cultivadad na interior de fragmento flarestal. As larras pretas verticais expressam a intervala de confianca a $5 \%$.

A ocorrência de Hypsipyla sp (Lepidoptera, Pyralidae) em ensaios de consorciação de meliaceas, mostraram a Vila et alii (1982) a persistência do ataque da broca do cedro durante o ano todo e em alguns casos os decréscimos em altura de uma leitura para outra revelaram a severidade do ataque, sem contudo ocasionar a morte das plantas.

Desenvolvendo estudos sobre a espécie, Souza (1981) observou que o cedro apresentou maior crescimento em altura, entre 9 a $25 \%$ de luminosidade relativa, também afirmando que a espécie exige sombreamento para desenvolvimento em sua fase jovem. Observou também que a incidência da broca do cedro ocorreu tanto em campo aberto como nas linhas de enriquecimento, sendo constatada uma maior freqüência nas linhas mais estreitas.

Para Inoue (1977), crescimento do cedro em seu estado juvenil não depende somente da intensidade luminosa, mas também da duração da radiação de 
energia, ou seja, do número de horas de insolação diária, o que também pode ser condição para outras espécies arbóreas do mesmo grupo sucessional. Então, o fator horas de insolação diária também pode ter influenciado o crescimento das cinco espécies a partir de junho, quando aumenta o comprimento dos dias.

\subsubsection{Altura média do guatambú}

O guatambú manteve um incremento em altura ascendente até o mês de fevereiro, continuando a partir daí, mas em menor escala, conforme pode ser acompanhado pela figura 18 .

\section{ALTURA MÉDIA DO GUATAMBÚ}

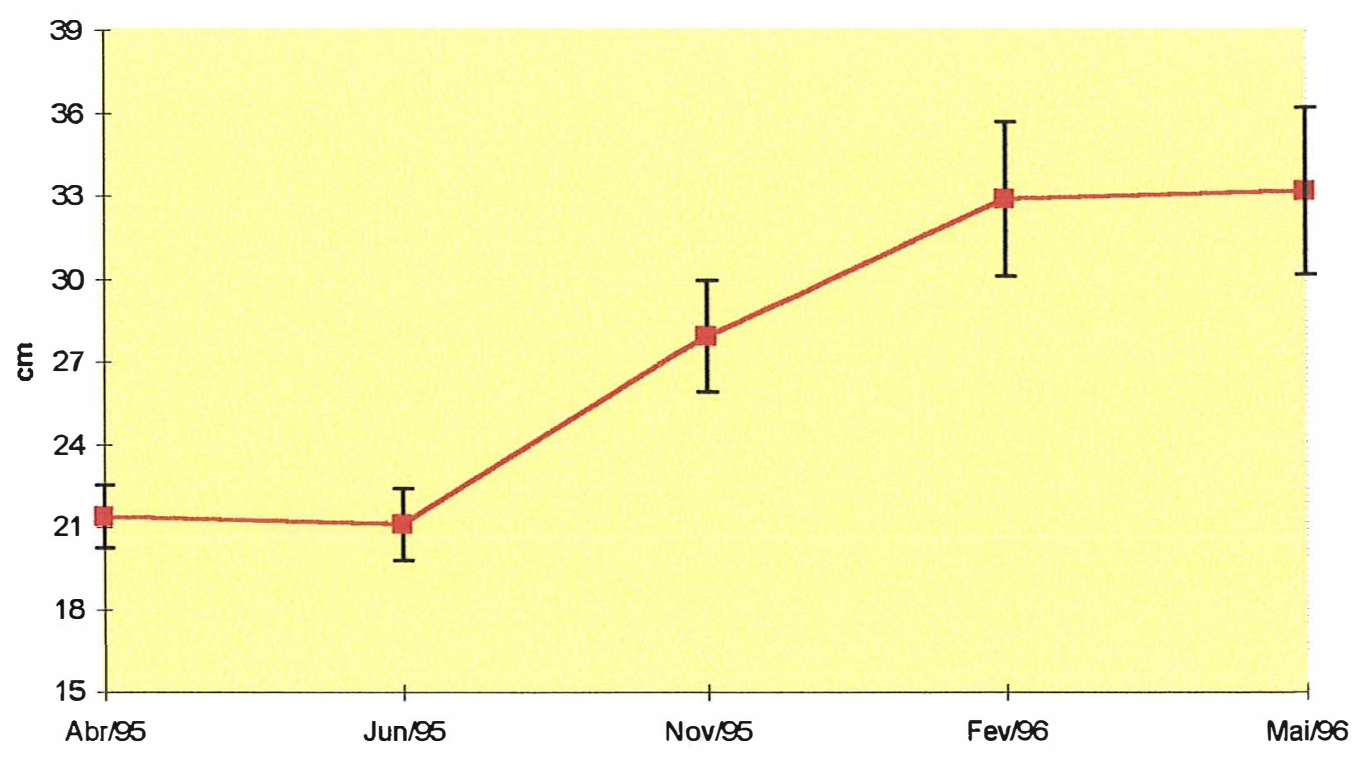

Figura 18. Altura média em centímetrod das mudas quatambí cultivado sob dossel de fragmento de mata semidecidua. As barras pretas verticais expressam a intervala de confianea a $5 \%$.

De forma semelhante às duas espécies anteriores, o guatambú também respondeu em maior crescimento no período de junho a novembro quando o conjunto de fatores microclimáticos foram mais favoráveis, mas continuou seu desenvolvimento até fevereiro apesar de uma maior restrição da luminosidade relativa, o que aponta para uma 
maior tolerância à sombra, enquadrando-se em estágio sucessional mais avançado que as duas primeiras espécies, como secundária tardia, sendo observado no interior da floresta pluvial atlântica segundo Lorenzi (1992).

\subsubsection{4 - Altura média do ipê-roxo}

O comportamento do ipê-roxo em crescimento mostrou-se semelhante às demais espécies no período de junho a novembro, conforme figura 19, mas continuou crescendo no período de novembro a maio, embora com menor intensidade, mostrando tolerância à sombra.

\section{ALTURA MÉDIA DO IPÊ-ROXO}

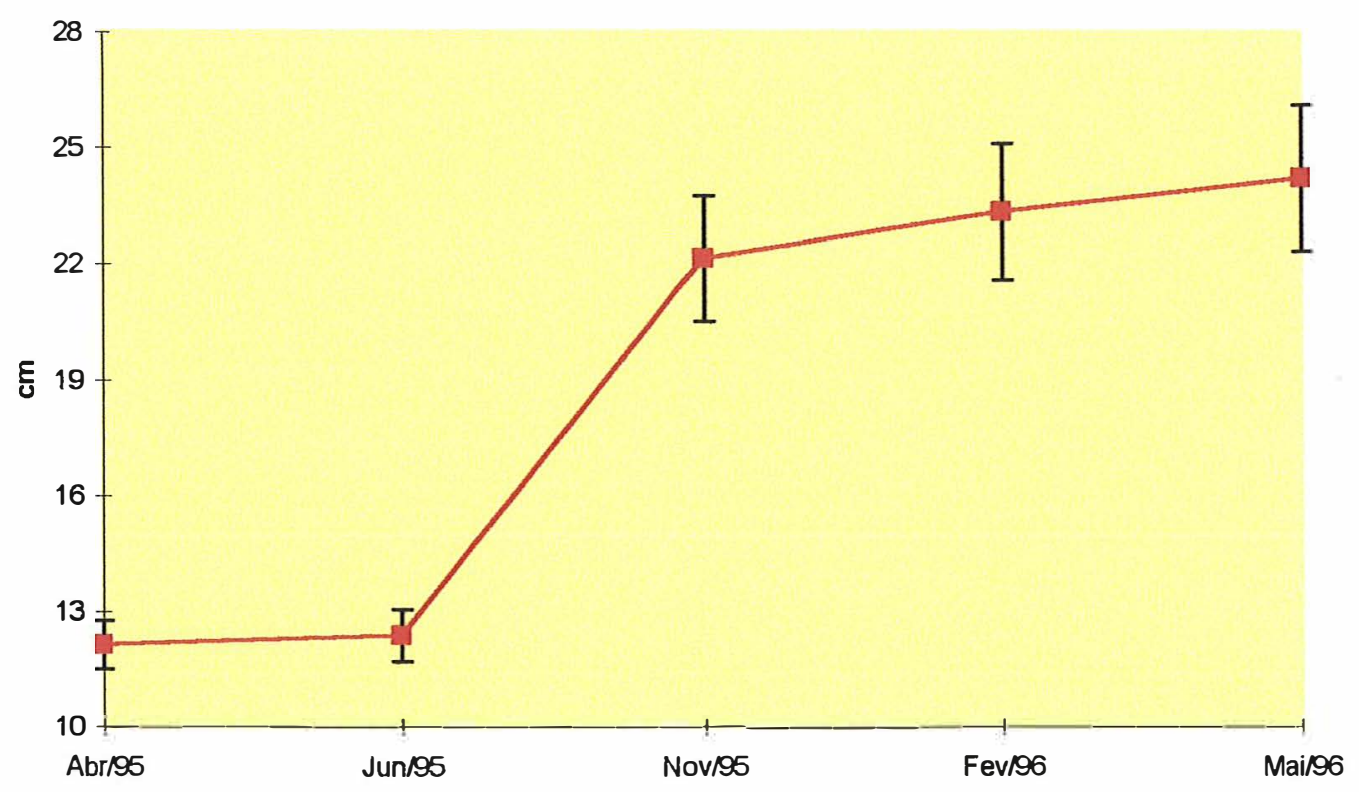

Figura 19 Atura média em centionerns das mudas de ipê-raxa, no periado de jual95 a mail 96 . cultivado cok dassel de flaresta cenidecidua. At harras pretas verticsis expressan a intervals de confianea a 5\%.

Engel \& Poggiani (1990) observaram através de ensaio em viveiro, que estádios juvenis de T. avellanedae obtiveram maiores crescimentos sob $68 \%$ de sombra ( $32 \%$ de luminosidade relativa), mostrando responder favoravelmente ao sombreamento. 
Ainda, segundo os mesmos autores, a espécie se enquadraria em uma etapa intermediária de sucessão secundária.

\subsubsection{Altura média do jatobá}

A espécie diferentemente das demais apresentou crescimento quase linear, conforme figura 20 , mesmo no período de maior enfolhamento e redução da luminosidade, demonstrando grande adaptação à sombra, podendo ser considerada como integrante de estágios sucessionais mais avançados (clímax).

O desenvolvimento da espécie no campo seria médio, segundo Lorenzi (1992), que também seria esciófita e seletiva xerófita, tolerando o sombreamento e o estresse hídrico.

\section{ALTURA MÉDIA DO JATOBÁ}

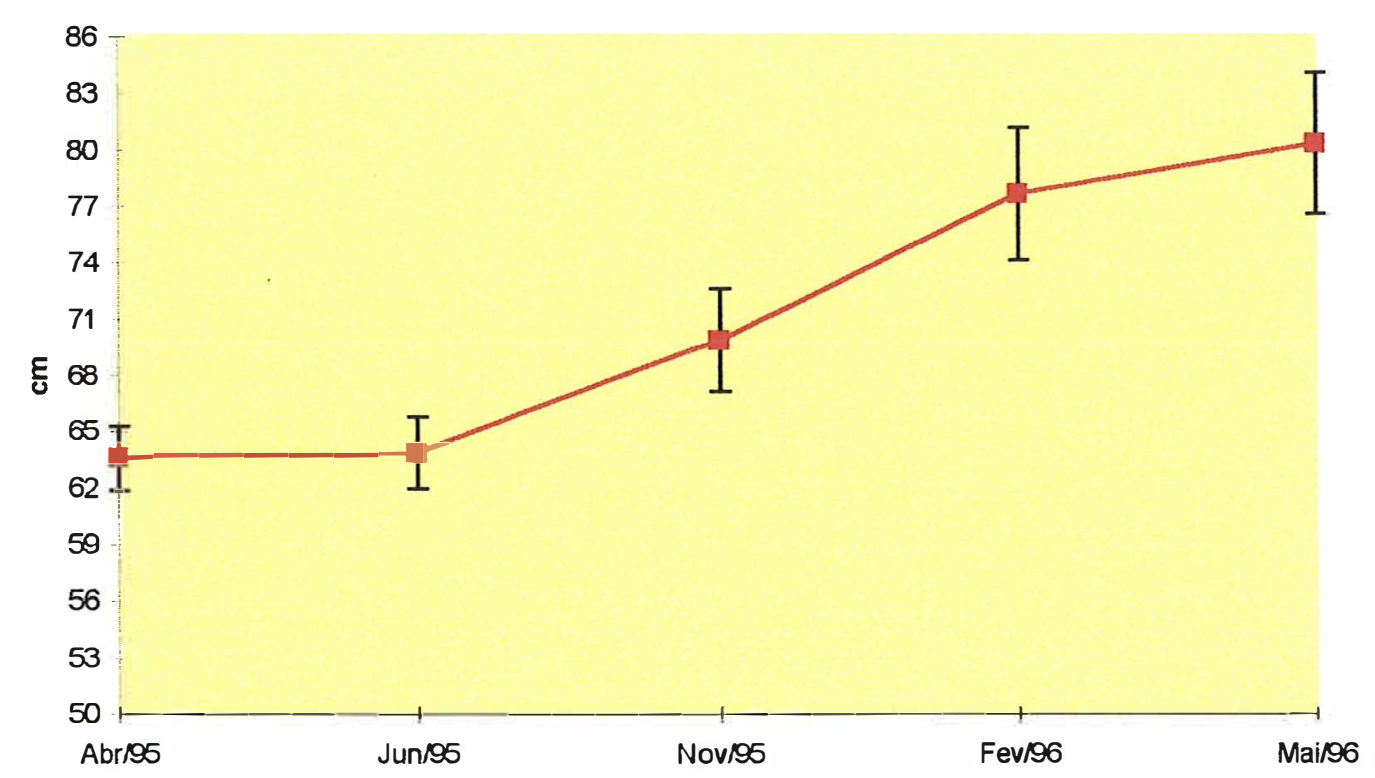

7iqura20. Aleura média em censimernes das mudas de Jatbai. no periado de jun/95 a mail96. cultivado sol dossel de fragments de mata senidecidua. At harras pretas voriceais expressans a intervals de confiamea a $5 \%$. 
Estudos desenvolvidos por Gurgel Filho et alii (1982) e Martins et alii (1990) observaram crescimento lento para a mesma.

Todas as espécies apresentaram um padrão de crescimento semelhante, determinados por fatores do meio e por fatores inerentes à cada espécie. Este padrão deve refletir o comportamento de crescimento das espécies arbóreas de ocorrência expontânea existentes no próprio fragmento, onde também ocorrem naturalmente as cinco espécies estudadas, com pequeno crescimento ou quase nulo nos meses com fatores como umidade, temperatura e luminosidade limitantes.

$\mathrm{O}$ conceito dos fatores limitantes e o ambiente fisico, abordado inicialmente como Lei do mínimo por Justus Liebig em 1840, citado por Odum(1988), diz que qualquer condição que se aproxime de ou exceda os limites de tolerância é uma condição ou um fator limitante.

O fato de todas as espécies terem apresentado crescimento no período, indica que apesar de baixo, o nível de luz não foi o fator mais restritivo, pois se manteve acima do ponto de compensação, permitindo acúmulo de biomassa, embora muito abaixo de seu ótimo.

O mesmo não se pode dizer sobre a precipitação e umidade do solo. Por exibirem período de grande deficiência consistiram em fator limitante de fato, durante o período de maio a setembro (seca).

A fase de crescimento mais acelerado inicia-se a partir de junho. Pelas medições terem sido trimestrais ou quadrimestrais, não se soube exatamente a data, mas provavelmente na primavera em outubro, quando inicia-se o período chuvoso e finda o período de déficit hídrico, coincidindo com aumentos na temperatura ambiente e do solo.

Percebe-se, para todas as espécies, três períodos distintos para o crescimento das mudas: um de grande crescimento, quando a maioria do fatores ambientais acompanhados foram favoráveis (junho/95 a fevereiro/96) e os outros dois, de pequeno crescimento, quando pelo menos um fator foi altamente desfavorável (abril/95 a junho/95 e fevereiro/96 a maio/96). 


\subsubsection{Incremento médio em altura}

O crescimento total médio no período de abril de 1995 a maio de 1996 é apresentado na tabela 4. As duas espécies que mais cresceram em altura foram o angico e o cedro que não apresentaram diferenças estatisticamente significativas entre si. São espécies de início de sucessão que apresentam crescimento rápido segundo Lorenzi (1992).

7abela 4. Médias finais de erescimeres das mudas em attura (eme):

\begin{tabular}{lcccc}
\hline \multicolumn{4}{c}{ INCREMENTO MÉDIO EM ALTURA } & \\
\hline & medias & & CV \\
ANGICO - Anadenathera macrocarpa & 25.82 & a & 99,55 \\
CEDRO - Cedrela fissilis & 25.61 & a & 97,16 \\
JATOBÁ - Hymenaea courbaril var. stilbocarpa & 20.30 & b & 88,49 \\
GUATAMBÚ - Aspidosperma parvifolium & 14.24 & C & 130,09 \\
IPÊ-ROXO - Tabebuia avellanedae & 13.51 & C & 87,81 \\
\hline
\end{tabular}

Médias acompanhadas da mesma letra não diferem entre sí pelo teste Wilcoxon a $5 \%$

O jatobá apresentou crescimento intermediário, acima do guatambú e do ipê-roxo, podendo ser melhor observado na figura 21, o que pode ser explicado pela espécie ser climácica, muito tolerante à sombra, o que fez com que mantivesse um crescimento quase que retilíneo naquelas condições de baixa luminosidade e superasse as outras duas espécies.

Pesquisando o comportamento de espécies florestais a pleno sol e em linhas de enriquecimento em Manaus, Neves et alii (1993) observaram que o cedro (Cedrela odorata) figurou entre as espécies que apresentaram o melhor desempenho em altura aos 12 meses de idade, apesar do ataque da broca do cedro. Também estava entre as espécies estudadas o jatobá (Hymenaea courbaril) mas não apareceu no grupo das espécies com maior desempenho entre as nove pesquisadas.

Acompanhando o desenvolvimento de espécies florestais do norte do Paraná a céu aberto, dentre as quais o angico (Piptadenia sp), cedro (Cedrela fissilis) e o 
ipê roxo (Tabebuia Heptaphylla), Takahashi \& Martins (1993) observaram diferenças estatisticamente significativas de crescimento entre as espécies. Dentre as espécies com crescimento rápido está o angico (Piptadenia rigida) e entre as de crescimento médio o cedro (Cedrela fissilis) e o jatobá (Hymenaea stilbocarpa).

A regeneração artificial de quatro espécies de elevado valor de mercado através de plantios em clareiras e trilhas de arraste, de exploração mecanizada foi pesquisada por Oliveira(1996) no Acre, observando que o cedro apresentou juntamente com a cerejeira o melhor desempenho em crescimento.

O comportamento de espécies nativas plantadas em sub-bosque de Eucalipto em área degradada foi acompanhado por Davide et alii (1996), onde observou que o angico vermelho (Anadenathera peregrina) destacou-se dentre as espécies que apresentaram maiores alturas. Também observou que o jatobá (Hymenaea courbaril) se manteve entre as espécies de menor crescimento.

Pesquisas com essências indígenas sombreadas desenvolvidas por Toledo Filho \& Parente (1982) mostraram que o cedro (Cedrela fissilis) e ipê-roxo (Tabebuia impetiginosa) mantiveram-se entre o grupo de menor crescimento.

\section{INCREMENTO MÉDIO EM ALTURA}

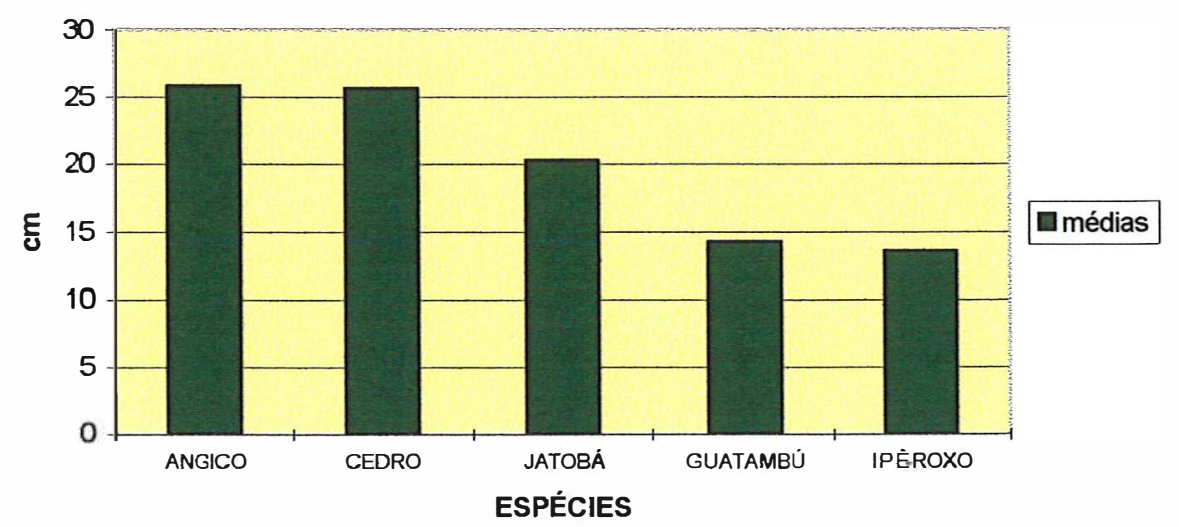

Figura 21. Incremento médis total em altura de cinca espécies cultivadas sol dossel de fragmenta flarestal nativa. 
Em pesquisas desenvolvidas na Colombia em Bajo Calima, San Jose del Guaviare e Tumaco, sobre comportamento de espécies florestais plantadas em linhas de enriquecimento, CONIF(1986) observaram que na região de San Jose del Guaviare o cedro (Cedrela odorata) destacou-se entre as que mais cresceram em altura, apesar do forte ataque da broca do cedro.

Estudando a competição de espécies florestais nativas em Petrolina PE, Lima et alii (1982) observaram que o angico (Anadenathera macrocarpa) foi a que alcançou o maior índice de crescimento.

A silvicultura do jatobá em povoamentos homóclitos coetâneos experimentais mostrou a Gurgel Filho et alii (1982) que a espécie embora ecologicamente se apresente em populações naturais de áreas de cerrado, reage significativamente à fertilidade do solo e apresenta crescimento inicial lento, aliado à ramificação simpodial. Pela pequena disponibilidade de material bibliográfico científico sobre o guatambú, que apresentou crescimento menor em relação ao angico, cedro e jatobá, observando trabalhos com a peroba (Aspidosperma polyneuron), espécie da mesma família e gênero botânicos, encontra-se em pesquisa desenvolvida por Gurgel Filho \& Gurgel Garrido (1982) que apresenta crescimento lento em cultivos homóclitos coetâneos experimentais, o que aponta para um comportamento típico da família. 


\subsection{2- Crescimento em diâmetro}

Todas as espécies apresentaram crescimento em diâmetro de caule no período, estatisticamente significativos, conforme apresentado pela tabela 5 , a despeito da limitação de parâmetros ambientais como a luminosidade e o estresse hídrico.

7abela 5. Diêmenos médios de caule inicial e final em milimetras, de mudas das cinco espécies plantadas sak tascel de fragmeats flarcest.

\begin{tabular}{|c|c|c|c|c|}
\hline \multicolumn{5}{|c|}{ DIÁMETROS MÉDIOS INICIAL E FINAL } \\
\hline & & médias & & $\mathrm{CV}$ \\
\hline \multirow[t]{2}{*}{ ANGICO } & inicial & 5,22 & a & 15.16 \\
\hline & final & 6,07 & $b$ & \\
\hline \multirow[t]{2}{*}{ CEDRO } & inicial & 5,46 & a & 41.24 \\
\hline & final & 11,3 & b & \\
\hline \multirow[t]{2}{*}{ GUATAMBÚ } & inicial & 4,27 & a & 29.22 \\
\hline & final & 4,76 & $b$ & \\
\hline \multirow[t]{2}{*}{ IPÊ-ROXO } & inicial & 3,41 & $a$ & 27.35 \\
\hline & final & 4,89 & $b$ & \\
\hline \multirow[t]{2}{*}{ JATOBÁ } & inicial & 8,13 & a & 16.88 \\
\hline & final & 9,43 & $b$ & \\
\hline
\end{tabular}

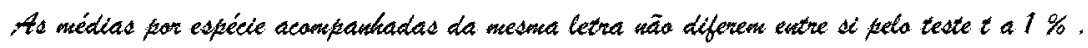

O comportamento das espécies com relação a este parâmetro foi semelhante ao ocorrido para crescimento em altura, indicando que, apesar de fatores microclimáticos limitantes como o baixo índice de luminosidade relativa, todas as espécies acumularam biomassa, ou seja, a luminosidade se manteve em taxas acima do ponto de compensação lumínico.

\subsubsection{1- Incremento médio em diâmetro}

A espécie que apresentou maior incremento foi o cedro, conforme apresentado na tabela 6 , que também apresentou juntamente com o angico, o maior incremento em altura, apontando para uma correlação positiva entre estes dois parâmetros para o cedro. 
Em pesquisas com indivíduos do gênero Cedrela spp Whitmore (1971) citado por Souza (1981), observou forte correlação entre a altura e o diâmetro de colo das plantas em Porto Rico.

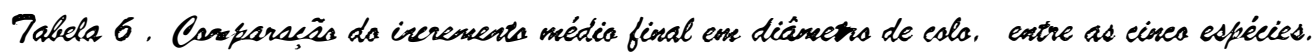

INCREMENTO MÉDIO EM DIÂMETRO DE COLO(mm)

\begin{tabular}{lccc} 
& média & \multicolumn{2}{c}{ CV } \\
\hline CEDRO - Cedrela fissilis & 6.14 & $\mathrm{a}$ & 86.99 \\
IPÊ-ROXO - Tabebuia avellanedade & 1.84 & $\mathrm{~b}$ & 136.05 \\
JATOBÁ - Hymenaea courbaril var. stilbocarpa & 1.75 & $\mathrm{~b}$ & 65.36 \\
ANGICO - Anadenanthera macrocarpa & 1.41 & $\mathrm{bc}$ & 81.82 \\
GUATAMBÚ - Aspidosperma parvifolium & 1.26 & $\mathrm{c}$ & 76.64 \\
\hline
\end{tabular}

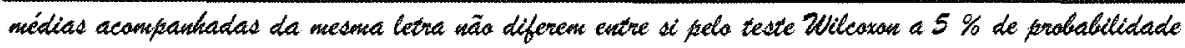

O ipê-roxo e o jatobá apresentaram um comportamento intermediário, sendo que o angico exibiu um incremento estatisticamente igual aos dois anteriores mas também igual ao guatambú. Apesar do angico ter apresentado o maior crescimento em altura juntamente com o cedro, obteve um dos menores desempenhos no incremento de diâmetro, não apresentando correlação entre incremento em diâmetro e altura. $\mathrm{O}$ seu grande incremento em altura, não seguido pelo incremento em diâmetro de colo pode significar estiolamento da espécie como estratégia de busca de ambiente com maior aporte de luz, por ser espécie de início de sucessão, mais exigente em luz.

Todas as quatro espécies, quando comparadas ao cedro apresentaram incremento de diâmetro muito pequeno, ou seja três vezes menor, o que pode ser atribuido ao baixo índice de luminosidade encontrado sob o dossel do fragmento, o que aponta para a possibilidade das três espécies apresentarem seu ponto de saturação lumínico muito acima do nível de luminosidade encontrado naquelas condições. 


\section{CRESCIMENTO EM DIÂMETRO DE COLO}

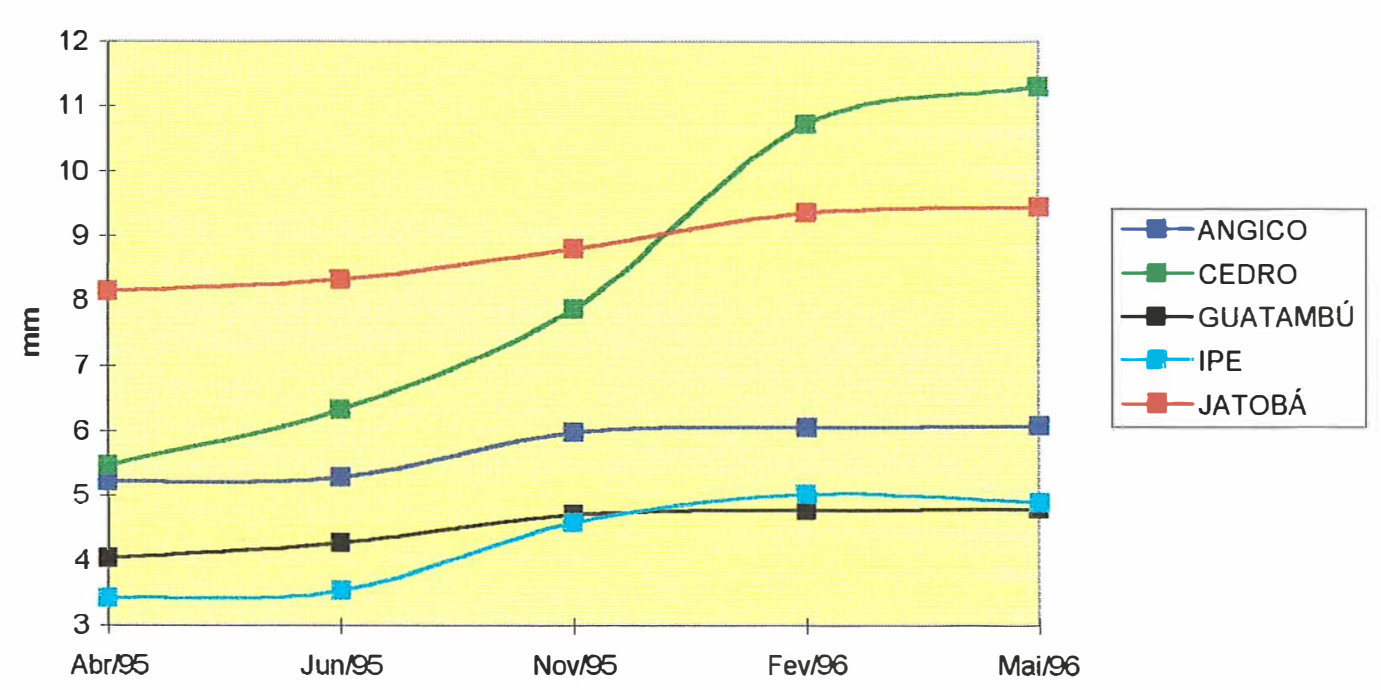

Figura 22. Cresciments en diâmetra de calo dac mudas dac cionea espécies plareadas sob dassel de fragments flarestal.

Observando-se a figura 22 , as curvas de crescimento em diâmetro se assemelham ao observado por Eggler (1955) citado por Kramer \& Koslowski (1972), onde o crescimento em diâmetro descreve uma curva sigmóide modificada, com um período evidente de maior incremento, seguido por outro de menor incremento ou mesmo de incremento nulo. No período de junho a novembro, todas as espécies apresentaram incremento positivo.

$\mathrm{O}$ angico e guatambú apresentaram comportamento muito semelhante, tendo seu período de maior incremento entre junho e novembro, respondendo ao maior aporte de luz, combinado com maior precipitação pluviométrica e temperaturas mais elevadas. Nota-se que de novembro de 1995 a maio de 1996, praticamente não houve incremento, apontando para a luminosidade como fator limitante no período, pois os fatores temperatura e umidade do solo não o eram, o que indica serem estas três espécies pouco tolerantes à sombra, pertencendo a grupo de espécies de início de sucessão. 
O ipê roxo apresentou incremento de junho de 95 a fevereiro de 96 , mostrando-se mais tolerante ao sombreamento que as duas primeiras, indicando ser de grupo sucessional mais avançado (secundária tardia).

O cedro foi a espécie que obteve o maior incremento em todos os períodos observados, com seu maior incremento no período de novembro de 1995 a fevereiro de 1997, quando o fator mais limitante foi a luminosidade relativa, o que aponta para uma maior tolerância à sombra que as três anteriores, demonstrando pertencer a um grupo sucessional mais avançado. Lorenzi (1992) afirma ser a espécie heliófita ou esciófita, dependendo das condições ambientais que se encontrar.

O jatobá manteve um incremento crescente também no período de luminosidade relativa baixa, indicando ser espécie tolerante ao sombreamento, situandose também em fase sucessional mais avançada.

\section{6 - Mortalidade}

Observou-se baixas taxas de mortalidade para as cinco espécies, conforme pode ser visualizado pela figura 23 , ficando todos abaixo de $5,09 \%$, índice mais alto atingido pelo cedro. Isto pode ser explicado em parte pelo fato do período de observação ter sido relativamente curto.

Os fatores que mais evidentemente influenciaram sobrevivência das cinco espécies foram a temperatura e precipitação pluvial. Considerando o déficit hídrico anual típico da região de mais de $100 \mathrm{~mm}$, que se estende pelo período de abril a outubro, provocando reduções na disponibilidade de água no solo neste período, este fator foi o que maiores restrições promoveu ao desenvolvimento e sobrevivência das mudas.

Sob um bosque em crescimento, a competição das raízes reduz substancialmente a quantidade de umidade do solo disponiveis para as plântulas. A combinação do tamanho reduzido das raízes e a pouca umidade do solo é frequentemente fatal às plântulas de sub-bosque (Spur, 1980). 
Segundo Bazzaz \& Pickett (1980), os períodos secos em florestas tropicais são mais comuns do se pensa ocorrer e a morte em larga escala de plântulas de algumas espécies em florestas maduras ocorrem mesmo durante períodos curtos de seca.

\section{MORTALIDADE}

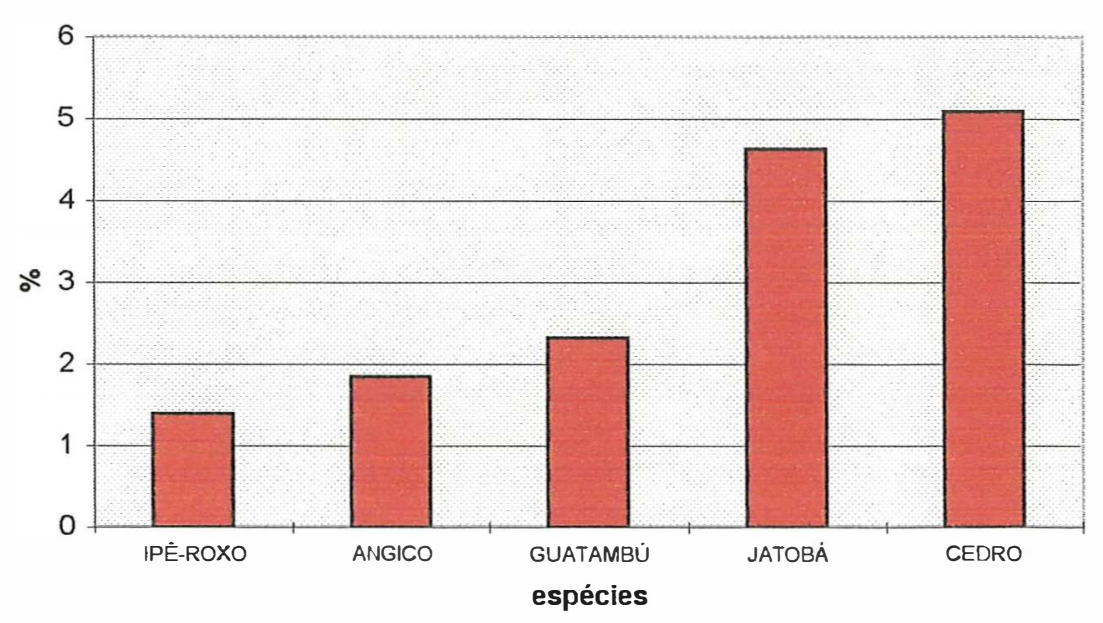

Figura 23. 2uadra de morralidade em parecoragen. das cines espécies flarestaic arbineas planeslas sob dassel de fragonenta de flaresta semidesidua.

Em nível de campo foi observado no período de seca vários indivíduos das parcelas experimentais com folhas murchas e muitas vezes secas ainda presas ao caule, bastante desidratados e mesmo muitos indivíduos jovens de espécies arbóreas de ocorrência espontânea no sub-bosque do fragmento apresentando-se totalmente desidratados e muitas vezes mortos. Também foram observados vários indivíduos nas parcelas experimentais com o ponteiro desidratado e morto, mas apresentando brotação lateral, o que muito influenciou na alta variância do ensaio.

Pelo fato de todas as espécies terem apresentado crescimento no período, significa que a quantidade de luminosidade disponível ao desenvolvimento das mudas, embora bastante limitada, aos níveis encontrados em florestas primárias, manteve- 
se provavelmente acima do ponto de compensação lumínico, permitindo-lhes acúmulo de biomassa, não indicando influência na taxa de mortalidade das mudas.

Outros fatores podem ter influenciado a taxa de mortalidade como a predação por mamíferos roedores, como a capivara, tendo sido observados danos em indivíduos das bordaduras das parcelas de Angico e ataque de formigas saúvas (Atta spp) em indivíduos de parcelas com guatambú.

No caso específico do cedro, que teve a menor taxa de sobrevivência, em parte a maior mortalidade pode ser atribuída ao ataque da broca Hypsipyla grandella.

Outro fenômeno observado comprometendo o desenvolvimento das mudas foi a queda de galhos secos das espécies arbóreas dos extratos superiores, muitas vezes danificando ou sufocando-as.

\section{7 - Recomendações de práticas silviculturais.}

Observando-se os vários fatores ambientais limitantes ao crescimento das mudas ao longo do período, pode-se recomendar um conjunto de práticas que poderão minimizar as influências restritivas, otimizando o crescimento de espécies florestais em plantio de enriquecimento.

No período de jun/95 (seca) observou-se um déficit hídrico acentuado, quando a umidade do solo encontra-se abaixo do ponto de murchamento, indicando que principalmente no início do desenvolvimento das mudas, existe a necessidade de irrigação das mesmas neste período, até que desenvolvam seus sistemas radiculares e possam explorar um volume maior de solo a profundidades maiores, permitindo-lhes acesso a maior quantidade de água. Recomenda-se também que o plantio seja feito a partir do mês de outubro, quando este fator não oferece restrições, proporcionando maiores condições de sucesso em sobrevivência e desenvolvimento das mudas em seu primeiro período de vida. 
Pelo fato do Índice de Luminosidade Relativa encontrado sob o fragmento ser semelhante ao do interior de matas primárias, sendo fator muito limitante ao desenvolvimento das mudas, principalmente a partir de novembro, aponta para a necessidade de escolha de áreas mais iluminadas para plantio das mudas dentro dos fragmentos. Existem várias formas para o incremento do aporte de luz a níveis satisfatórios ao desenvolvimento das mudas. Uma delas, seria o plantio em clareiras, seguido de manejo das outras espécies arbóreas ou lianas que viessem a competir este fator com as mudas plantadas. Outra forma seria a abertura de picadas nos fragmentos, onde as mudas seriam plantadas em linhas de enriquecimento, seguidas de manejo das espécies que viessem a competir este fator ambiental com as mudas plantadas.

A utilização de espécies mais tolerantes ao déficit hídrico bem como ao sombreamento também seria uma estratégia importante durante a escolha das espécies para enriquecimento de fragmentos.

$\mathrm{O}$ cedro mostrou-se particularmente promissor para enriquecimento de fragmentos por ter apresentado maiores incrementos em altura e diâmetro de caule, a despeito do ataque de broca.

\section{8 - Considerações sobre metodologia para implantação de ensaios para enriquecimento de fragmentos florestais.}

Considerando as variáveis não controladas serem elevadas quando da implantação de ensaios no ambiente natural e que seus efeitos sobre os resultados de pesquisas neste ambiente traduzirem-se em grandes dispersões dos dados acompanhados, exibindo altos coeficientes de variação, algumas medidas seriam recomendáveis para futuras pesquisas científicas de fatores ambientais e seus efeitos no desenvolvimento de estágios juvenis de espécies arbóreas.

A primeira delas seria definir quais os parâmetros a serem acompanhados, que tenham grande influência no desenvolvimento das mudas e possam ser efetivamente medidos. A segunda, seria definir áreas para implantação do 
experimento dentro dos fragmentos, onde as condições para os fatores a serem observados sejam as mais uniformes possíveis. Em terceiro, definir os prováveis fatores com influências que não sejam do interesse da pesquisa acompanha-los, ou que sejam de dificil mensuração, ou ainda que possam mascarar efeitos dos fatores medidos, a fim de serem isolados ou minimizados.

Como é muito dificil a nível prático conseguir definir áreas homogêneas de tamanho razoável para instalação das parcelas experimentais sob fragmento, a estratégia de se definir cada muda como sendo uma parcela (one tree plot) significará redução do tamanho da área experimental, facilitando a definição da locação das parcelas em áreas homogêneas menores, reduzindo as dispersões provocadas por este lado, mas obviamente podendo aumentar a dispersão pela redução do número de indivíduos observados em cada parcela.

As medições dos dados ambientais como luminosidade, umidade do solo, temperatura ambiente e do solo devem ser tomadas com maior freqüência, devendo ser no mínimo mensal.

As amostras de solo para análise de umidade devem ser preferencialmente indeformadas, colhidas através de anéis volumétricos, segundo Brunini et alii (1975), permitindo assim maior precisão na determinação da água disponivel, considerando os aspectos dinâmicos do fluxo de água no solo, sua textura e estrutura.

Finalizando, pelo fato das árvores possuirem ciclos de vida longos, o período de observação do seu crescimento e de fatores ambientais que o influenciam deve ser mais longo. 


\section{5 - CONCLUSÕES}

1- A quantidade média de luz observada sob o dossel do fragmento florestal apresentou oscilações no período, porém em um patamar muito baixo, variando de 0,83 Klux a 2,00 Klux, valores semelhantes aos encontrados no interior de florestas tropicais pouco alteradas pelo homem(primárias), mesmo no período de maior desfolhamento, quando se manteve mais elevada.

2- A temperatura do solo acompanhou a temperatura ambiente, mantendo-se ligeiramente abaixo desta, durante todo o período experimental. Sendo fator diretamente associado à radiação solar, também variou ao longo do ano.

3- A umidade do solo seguiu a precipitação pluvial, declinando a níveis abaixo do ponto de murchamento no mês de junho de 1995. Este fator mostrou-se altamente limitante ao desenvolvimento das mudas.

4- As espécies apresentaram durante o ano, dois períodos distintos de crescimento: um, marcado por um maior crescimento, compreendido entre julho e fevereiro (primavera/verão), coincidindo com o período de maiores precipitações pluviais, de aumento do comprimento do dia, da elevação da temperatura ambiente e do solo e maior disponiblidade de luz. Outro, compreendido entre março e julho (outono/inverno), marcado pelas temperaturas mais baixas, menores disponibilidades de luz, déficit hídrico e provavelmente pelo comprimento do dia menor.

5- As espécies que mais cresceram em altura foram o angico e o cedro, seguidos pelo jatobá com crescimento intermediário. O guatambú e o ipê-roxo obtiveram 
o menor desempenho em crescimento. O cedro apresentou o melhor desempenho em relação ao diâmetro de colo.

6- A taxa de mortalidade foi baixa para todas as espécies, sendo maior para o cedro pelo ataque de broca.

7- Recomendações: são práticas silviculturais mais recomendáveis o plantio das mudas a partir de outubro de cada ano, irrigação nos primeiros anos nos períodos de défict hídrico e utilização de espécies mais resistentes ao estresse hídrico; plantio em clareiras ou em linhas de enriquecimento e manejo das espécies competitivas às cultivadas, garantindo maior aporte de luz.

As metodologias recomendadas como sendo as mais adequadas à instalação de experimentos dessa natureza são: uma definição criteriosa dos parâmetros a serem acompanhados e da metodologia de coleta e análise dos dados; promoção de meticuloso controle local; utilização de parcelas de tamanho reduzido, como "one tree plot"; promoção de medições com freqüência mensal e por um período de tempo de pelo menos dois anos. 


\section{REFERÊNCIAS BIBLIOGRÁFICAS:}

ACOT, P. História da Ecologia. Rio de Janeiro: Editora Campus, 1990. 212 p.

AMO, S. R.; GOMEZ-POMPA, A. Crescimiento de estados juveniles de plantas en selva tropical alta perennifolia. In: GOMEZ POMPA, A. et alii. Investigaciones sobre la regeneración de selvas altas em Veracruz, México. México: Compañia Editorial Continental S.A, 1979. p 549- 65.

AMO, S. R. Alguns aspectos de la influencia de la luz sobre el crescimiento de estados juveniles de especies primarias. In: GOMEZ-POMPA, A; AMO, S.R. Investigaciones sobre Recursos Bioticos. Mexico: Editora Alhambra Mexicana S.A., 1985, p. 79-92.

BARBOSA, D. C. A. Estudos ecofisiológicos em Anadenanthera macrocarpa (Benth) Brenan: aspectos da germinação e crescimento. São Paulo. Tese de Doutorado. 1980.

BAZZAZ, F. A.; PICKETT, S. T. A. Physiological ecology of tropical succession: a comparative review. Annual Review of Ecology and Systematics. 11:287-310, Copyright, California, 1980.

BRASIL 1.Instituto Brasileiro de Geografia. Departamento de Cartografia. Carta do Brasil - Esc. 1:50.000. Brasília, 1972, folha SF-23-V-A-IV-1.

BRUNINI, O. ; REICHARDT, K.; GROHMANN, F. Determinação da água disponível em latossolo roxo em condições de campo. In: XV CONGRESSO BRASILEIRO DE CIÊNCIA DO SOLO. Campinas, 14 a 20 de julho de 1975. Anais. Campinas, Sociedade Brasileira de Ciências do Solo. p. 81 a 87. 
BUDOWSKI, G. Distribuition of tropical a mericam rain forest species in the light of sucessional process. Turrialba. 16:3, 278-85, 1965.

CARVALHO, P.E.R. Resultados experimentais de espécies madeireiras sobre essências nativas no Estado do Paraná. In: CONGRESSO NACIONAL SOBRE ESPÉCIES NATIVAS, $1^{\circ}$. Campos do Jordão, 1982. Anais. São Paulo: Instituto Florestal, Silvicultura em São Paulo, 1982. 2: 747-65.

CESAR, O. Composição florística, fitossociológica e ciclagem de nutrientes em mata mesófila semidecídua (Fazenda Barreiro Rico, Anhembí, SP). Rio Claro, 1988. Tese de Livre Docencia. UNESP.

CLARK, D. A.; CLARK, D. B. Life history diversity of canopy and emergent trees in a neotropical rain forest. Ecological-monographs. San Pedro, Costa Rica. 62(3), 31544,1992

CONIF. Corporacion Nacional de Investigacion y Fomento Forestal. Resultados del comportamiento de espécies forestales plantadas em lineas de enriquecimiento, en Bajo Calima, Sam Jose del Guaviare y Tumaco. Colômbia, Bogotá, 1986. v.19, 133.

DAVIDE, A. C.; FARIA, J.M.R.; BOTELHO, S. A. Comportamento de espécies nativas plantadas em sub-bosque de Eucalipto em área degradada. In: FOREST 96: $4^{0}$ SIMPÓSIO INTERNACIONAL SOBRE ECOSSISTEMAS FLORESTAIS, Belo Horizonte, 1996.Anais. Belo Horizonte. p 280-1.

DPRN. Projeto Olho Verde. Departamento de Proteção aos Recursos Naturais Renováveis, Secretaria de Meio Ambiente do Estado de São Paulo. 1993.

EMBRAPA. Empresa Brasileira de Pesquisa Agropecuária. Serviço Nacional de Levantamento e Conservação de Solos. Rio de Janeiro: SNLCS, 1979, 105 p. (Manual de métodos de análise de solos).

ENGEL, V.L.; POGGIANI, F. Influência do sombreamento sobre o crescimento de mudas de algumas essências nativas,e suas implicações ecológicas e silviculturais. Piracicaba, IPEF, 1990, p 1-10. (43/44). 
EVANS, L. T. The effect of light on plant growth, development and ield. In: Plant Response to Climatic Factors. Procedings. UNESCO. Paris, 1973. p. 21-35.

FETCHER, N.; STRAIN, B.R.; OBERBAUER, S.F. Effects of light regime on the growth, leaf morphology, and water relatoins of seedlings of two species of tropical trees. Oecologia. 58(3): 314-19, 1983.

FRANÇA, J.T.; POGGIANI, F. Variação do microclima em áreas com diferentes idades de sucessão secundária na Floresta Nacional do Jamarí, RO. In: CONGRESSO DE ECOLOGIA, $3^{\circ}$, UNB/DF, Brasilia, 1994. Anais. Brasilia, p. 422-23.

GOMEZ-POMPA, A. Posible papel de la vegetación secundaria em la evolución de lla flora tropical. Biotropica. 3(2): 125-35, 1971.

GURGEL FILHO, O.M.; MORAES, J.L.; MARAIS, E, a. Caracteres silviculturais e competição entre espécies folhosas. In: CONGRESSO NACIONAL SOBRE ESPÉCIES NATIVAS, $1^{\circ}$. Campos do Jordão, 1982. Anais. Silvicultura em São Paulo. São Paulo, Instituto Florestal, 1982 . 2:895-900.

b. Silvicultura de essências indígenas sob povoamentos homóclitos coetâneos experimentais. 4 - Jatobá (Hymenaea stilbocarpa Hayne.). In: CONGRESSO NACIONAL SOBRE ESPÉCIES NATIVAS, $1^{\circ}$. Campos do Jordão, 1982. Anais. Silvicultura em São Paulo. São Paulo, Instituto Florestal, 1982. 2:857-861.

GURGEL FILHO, O.M.; GURGEL GARRIDO, L.M.A. Silvicultura de essências indígenas sob povoamentos homóclitos coetâneos experimentais 8 - Peroba Rosa (Aspidosperma polineuron). IN: CONGRESSO NACIONAL SOBRE ESPÉCIES NATIVAS, $1^{\circ}$. Campos do Jordão, 1982. Anais. São Paulo. Silvicultura em São Paulo, Instituto Florestal, 1982. 2:878-83.

HALLÉ, F.; OLDEMAN, R.A.A.; TOMLINSON, P.B. Tropical trees and forest - an architectural analysis. New York: Springer-Verlang, 1978. $411 \mathrm{p}$.

IGBOANUGO, A.B.I. Water deficit and changes in water relations of sun and shade leaves of Quercus petraea (Matt.) Libl. and Nothofagus procera (Poepp. et Endl.) Oerst seedlings. Botanical Bulletin of Academia Sinica. Taiwan, 29:3, 153-62;24, 1988. 
INOUE, M.T.; Torres, D.V. Comportamento do crescimento de mudas de Araucária Augustifolia (Bert.) O. Ktze. em dependência da intensidade luminosa. Floresta, $11(1): 7-11,1980$.

INOUE, M.T.; A autoecologia do gênero Cedrela spp: efeitos na fisiologia do crescimento no estágio juvenil em função da intensidade luminosa. Floresta, 8(2): 58-61, 1977.

Fundamentos ecofisiológicos para a silvicultura de Cedrela spp. Curitiba, 1978, 91 f. Tese. Universidade Federal do Paraná.

INSTITUTO FLORESTAL. Inventário Florestal do Estado de São Paulo. São Paulo, 1993.

JACOBS, M. The tropical rain forest: a first enconter. Berlin, Springer-Verlag, 1988. $295 \mathrm{p}$.

JESUS, R. M; COUTO, J.T.Z.; GARCIA, A. Manejo florestal em Linhares 1 - crescimento em função de diferentes níveis de intervenção. In: CONGRESSO NACIONAL SOBRE ESSÊNCIAS NATIVAS, $2^{\circ}, 1992$. Anais. Campos do Jordão, 1992. p. 653-60.

JESUS, R.M.; DIAS, G.B.N.; CAROSO, E.M.; MENANDRO, M. S. Enriquecimento em matas degradadas e em formação de menor potencial. In: CONGRESSO NACIONAL SOBRE ESPÉCIES NATIVAS, $1^{\circ}$. Campos do Jordão, 1982. Anais. Silvicultura em São Paulo. São Paulo, Instituto Florestal, 1982.

KOZLOWSKI, T.T. Tree growth. New York, The Ronald Press Company, 1962. p 14970.

KRAMER, P.J.; KOZLOWSKI, T.T. Fisiologia das árvores. Lisboa. Fundação Calouste Gulbenkian, 1972, 745 p.

LIMA, P.C.F.; SOUZA, S. M.; DRUMOND, M. A. Competição de espécies florestais nativas em Petrolina - PE. In: CONGRESSO NACIONAL SOBRE ESPÉCIES NATIVAS, $1^{\circ}$. Campos do Jordão, 1982. Anais. Silvicultura em São Paulo. São Paulo, Instituto Florestal, 1982. 2:1139-48.

LORENZI, H. Árvores Brasileiras. Nova Odessa: Editora Plantarum, 1992. 354 p. 
MADSEN, P. Growth and survival of Fagus sylvatica seedlings in relation to light intensity and soil water content. Scandinavian Journal of Forest Research. Denmark, 9(4), 316-22, 1994.

MARTÍNEZ-RAMOS, M. Claros, ciclos vitales de los arboles tropicales y regeneracion natural de las selvas altas perennifolias. In: GOMES-POMPA, A. \& AMO, S.R. del. eds. Investigaciones sobre la Regeneracion de Selvas Altas en Veracruz, México. México: Editorial Alhambra Mexicana, 1985., p 191 a 239. (Tomo 2).

MARTINS, R. et alii. Desenvolvimento de algumas espécies florestais em plantio de enriquecimento. In: CONGRESSO FLORESTAL BRASILEIRO, $6^{\circ}$. Campos do Jordão, 1990. Anais. São Paulo, 1990. p. 239-42.

MCCAIN, D.C; CROXDALE, J; MARKLEY, J. L. Water is allocated differently to chloroplasts in sun and shade leaves. Plant physiology.86(1): 16-8, 1988.

MCKEE, K.L. Interspecific variation in growth, biomass partitioning and defensive characteristics of neotropical mangrove seedlings: response to light and nutrient availability. American Journal of Botany. USA, 82(3); 299-307, 1995.

MOLAS, F.P.J.; PRETZSCH, J. Enriquecimiento del bosque nativo degradado: una alternativa silvicultural para em Paraguay. Revista Forestal, Assuncion. v.2:20-8, 1989.

MORELlATO, L. P. C. Sazonalidade e Dinâmica de Ecossistemas Florestais na Serra do Japi: Ecologia e preservação de uma área florestal no sudeste do Brasil. Campinas: Editora da UNICAMP, 1992. p. 98-106.

NEVES, E. J. M. ; SILVA, S. E. L.; MATOS, J. C. S.; CANTO, A. C. Comportamento de espécies florestais a pleno sol e em linhas de enriquecimento em Manaus - AM. In: CONGRESSO FLORESTAL PANAMERICANO, $1^{\circ}$. CONGRESSO FLORESTAL BRASILEIRO, $7^{\circ}$. Anais. Curitiba, 1993. p 756.

MINISTÉRIO DAS MINAS E ENERGIA. Projeto RADAMBRASL: levantamento de recursos naturais. Rio de Janeiro, 1983. Fls. SF 23-4. (vol. 32).

ODUM, E. P. Ecologia. Rio de Janeiro: Editora Guanabara Koogan, 1988. 434 p.

OLIVEIRA, M. V. N. Regeneração artificial de quatro espécies de elevado valor de mercado através de plantios em clareiras e trilhas de arraste, de exploração florestal mecanizada. In: FOREST 96: SIMPÓSIO INTERNACIONAL SOBRE 
ECOSSISTEMAS FLORESTAIS, $4^{0}$. Belo Horizonte - MG. Anais, Belo Horizonte, p 270-2, 1996.

PAGANO, S. N. Estudo Florístico, Fitossociológico e de ciclagem de nutrientes em mata mesófila semidecídua no município de Rio Claro, SP. Rio Claro, SP, 1985. Tese de livre docência. UNESP.

PEDRO JÚNIOR, M. J.; ALFONSI, R. R.; CAMARGO, M. B. P.; ORTOLANI, A. A.; BRUNINI, O. Disponibilidade de radiação solar global para o Estado de São Paulo. Campinas: IAC, 1989. 13 p. (Boletim Técnico n $\left.{ }^{\circ} 123\right)$.

POGGIANI, F; BRUNI, S; BARBOSA, E. S. Q. Efeito do sombreamento sobre o crescimento das mudas de três espécies florestais. Revista do Instituto Florestal, $\mathrm{n}^{\circ} 4$. São Paulo. Instituto Florestal, p 564-9. 1992.

POGGIANI, F.; MONTEIRO JUNIOR, E. S. Deposição de folhedo e retorno de nutrientes ao solo numa floresta estacional semidecídua em Piracicaba, SP. In: CONGRESSO FLORESTAL BRASILEIRO, $6^{\circ}$. Campos do Jordão, SP. SBS/Sbef. Anais, Campos do Jordão, 1990. p 596-602.

RAMOS, G.; GRACE, J. The effects of shade on the gas exchange of seedlings of four tropical trees from Mexico. Forest abstract. Edimburgh, UK, 4(5): 667-77; 46 ref, 1990.

RIZZINI, C.T. Árvores e madeiras úteis do Brasil. Curitiba: Editora Edgard Blucher Ltda, , 1978, 296 p.(Manual de Dendrologia Brasileira).

SALIS, S.M.; MATTOS, P.P. Fenologia de arbóreas nativas com potencial madeireiro na sub-região da Nhecolândia, pantanal Mato-Grossense. In: $1^{\mathrm{O}}$ CONGRESSO FLORESTAL PANAMERICANO. CONGRESSO FLORESTAL BRASILEIRO, $1^{\circ}$. Anais. Curitiba, PR, p 762, 1993. 
SATTLER, M.A. Arborização urbana e conforto ambiental. In: CONGRESSO BRASILEIRO SOBRE ARBORIZAÇÃO URBANA, 1ํ, Vitória, 1992. Anais. Vitória, Prefeitura Municipal de Vitória, 1992. Vol. 1, p.15-28.

SERRA FILHO, R. et alii. Levantamento da cobertura vegetal natural e do reflorestamento no Estado de São Paulo. Instituto Florestal, São Paulo, 11:1-53, 1975. (Boletim técnico).

SOUZA, L.J.B. Fotomorfose e Crescimento de Cedrela fissilis vell no viveiro e no plantio de enriquecimento em linha. Curitiba, 1981, 117 p. Dissertação de Mestrado, UFPR.

SPURR, S. J.; BARNES, B. V. Ecologia Florestal. New York, Ronald Press, 1980. 571 p.

STADTMULLER, T. Funciones climáticas e hidrológicas de los bosques con enfasis em los trópicos. El Chasqui, Turrialba, 6(16):3-10, 1988.

TAKAHASHI, L. Y.; MARTINS S. S. Desenvolvimento de espécies florestais do norte do Paraná a céu aberto. In: CONGRESSO FLORESTAL PANAMERICANO, $1^{\mathrm{O}}$. CONGRESSO FLORESTAL BRASILEIRO, $7^{\mathrm{O}}$. Anais. Curitiba, 1993. p. 758.

TOGNETTI, R.; MICHELOZZI, M.; BORGHETTI, M. Response to light shade grown beech seedlings subjected to different watering regimes. Tree Physiology. Italy, 14( 7/9): 751-58, 1994.

TOLEDO FLLHO, D.V.; PARENTE, P.R. Essências Indígenas Sombreadas. In: CONGRESSO NACIONAL SOBRE ESPÉCIES NATIVAS, $1^{\circ}$. Campos do Jordão, 1982. Anais. Silvicultura em São Paulo. São Paulo, Instituto Florestal, 1982. 2:948-56.

TURNER, I.M. A shading experiment on some tropical rain forest tree seedlings. Journal of Tropical Forest Science. Oxford - UK, 1(4), 383-89, 1989.

VANCE, N.C.; RUNNING, S.W. Ligth reuction and moisture stress: effects on growth and water relations of western larch seedlings. Canadian Journal of Forest Research. 15(1), 72-7, 1985.

VIANA, V. M.; TABANEZ, A. J. A.; MARTINEZ, J. L. A. Restauração e manejo de fragmentos florestais. In: CONGRESSO NACIONAL SOBRE ESSÊNCAIS NATIVAS, $2^{\circ}$, Campos do Jordão, 1992. Anais, 400-6. 
VILA, W. M.; TEIXEIRA, E. P.; GARRIDO, M. A. O.; ROSA, P.R.F.; SOUZA, W. J. M.; GURGEL GARRIDO, L.M.A. In: CONGRESSO NACIONAL SOBRE ESPÉCIES NATIVAS, $1^{\circ}$. Campos do Jordão, 1982. Anais. Silvicultura em São Paulo. São Paulo, Instituto Florestal, 1982. 2:1209-12.

VITOR, M.A. de M. A devastação florestal. 1975.

WALDHOFF, F; VIANA, V.M. Efeito de borda em um fragmento de mata atlântica em Linhares. In: CONGRESSO FLORESTAL BRASILEIRO, $7^{\circ}$, Curitiba. Sociedade Brasileira de Silvicultura. Unipress Empresa de Comunicação S/A Ltda.Anais. Curitiba, 1993.p 41-44.

WHATLEY, J. M.; WHATLEY, F. R. A luz e a vida das plantas. São Paulo, EDUSP, 1982.

WIEBEL, J. CHACKO, E. K. ; DOWNTON, S. J. S. ; LUDDERS, P. Influence of irradiance on photosynthesis, morphology and growth of mangosteen (Garcinia mangostana L.) seedlings. Tree Physiology, Austrália, 14(3), 263-74, 1994.

WRIGHT, S. J.SCHAIK, C. P.; VAN-SCHAIK, C. P. Light and the phenology of tropical trees. American naturalist, USA, 143(1), 192-1991994. 